\title{
LA RECEPCIÓN DE AUTORES GRIEGOS O LATINOS EN LA GENERAL ESTORIA DE ALFONSO X (PRIMERA PARTE)*
}

\author{
Juan Antonio López Férez \\ Universidad Nacional de Educación a Distancia (UNED). Madrid \\ jalferez@flog.uned.es
}

\section{RESUMEN}

Este trabajo intenta situar cronológicamente las obras y autores griegos o latinos mencionados en la Primera parte de la General Estoria, y, a la vez, añadir algunas aclaraciones sobre los nombres propios de esos escritores, que, con frecuencia, nos han llegado con grafías irreconocibles en la obra alfonsí. En total, la aportación recoge 32 autores griegos y 15 latinos, distribuidos, en lo posible, de acuerdo con un orden cronológico.

PALABRAS CLAVE: General Estoria, autores griegos, autores latinos.

\author{
THE RECEPTION OF GREEK OR LATIN AUTHORS \\ IN THE GENERAL ESTORIA OF ALFONSO X (FIRST PART)
}

\section{ABSTRACT}

This work wants to place chronologically the Greek or Latin works and authors mentioned in the First part of the General Estoria, and, at the same time, adds some clarifications about the proper names of these writers, which, frequently, have come down to us with unrecognizable spellings in the Alfonso's work. In total, the contribution includes 32 Greek and 15 Latin authors, distributed, when possible, in chronological order.

KEYWORDS: General Estoria, Greek/Latin authors.

\section{GENERALIDADES}

1.1. La General Estoria (=GE, en lo sucesivo), redactada entre 1272 y 1284 , año de la muerte del rey sabio, pretendía abarcar la historia de la humanidad desde la creación del mundo hasta la época del monarca. Aunque tan magno empeño no pudo cumplirse, pues llegó sólo hasta los años previos al nacimiento de Cristo, lo que nos ha llegado constituye un precioso legado de enorme importancia, vastedad y pluralidad. La obra enriquece los datos traducidos y sacados de la Biblia con bastantes referencias ofrecidas por los escritores más relevantes de la Antigüedad tanto griegos como latinos, y, además, entre otros, los hebreos y egipcios. Los materiales son de muy diversa procedencia, por lo que el escritorio alfonsí tuvo que hacer un gran esfuerzo 
para traducirlos ${ }^{1}, y$, en todo caso, armonizarlos y conseguir un estilo coherente y relativamente unitario. Como el rey confiesa en algunas ocasiones, la $G E$ es una labor de equipo que pasó por diversas revisiones, entre las que destaca la llevada a cabo por él mismo, muy preocupado por la corrección del castellano ${ }^{2}$. Respecto a la intervención real en la composición de la $G E$ es relevante un pasaje como el siguiente (GE I.16.14):

assí como dixiemos nós muchas vezes el rey faze un libro non por quel él escriva con sus manos, mas porque compone las razones d'él e las emienda e yegua e endereça e muestra la manera de cómo se deven fazer, e desí escrívelas qui él manda, peró dezimos por esta razón que el rey faze el libro. Otrossí cuando dezimos el rey faze un palacio o alguna obra non es dicho porque lo él fiziesse con sus manos, mas porquel mandó fazer e dio las cosas que fueron mester pora ello; e qui esto cumple aquel á nombre que faze la obra, e nós assí veo que usamos de lo decir.

A pesar de todos los esfuerzos del equipo de trabajo responsable de la magna obra, las digresiones y paréntesis no son pocos, y, sobre todo, las contradicciones respecto a las versiones seguidas acerca de un mismo suceso, hasta tal punto que, a veces, lo que se afirma en un lugar se pone en duda o se niega en otro ${ }^{3}$.

La $G E$ se inserta en el movimiento cultural europeo que siguió al IV Concilio de Letrán (1215-1216). Uno de los efectos de aquél fue la versión de la Biblia al castellano entre los años 1250-1280, y al francés, algo más tarde ${ }^{4}$. Pues bien, la $G E$ contiene la segunda traducción castellana ${ }^{5}$, no literal ${ }^{6}$, de la Vulgata latina de San Jerónimo ${ }^{7}$. Unas décadas antes, se había redactado, también en castellano, la Biblia preal-

* Elaborado dentro del Proyecto FFI2017-82850-R del Ministerio español de Economía, Industria y Competitividad.

[Conste mi agradecimiento a los dos revisores anónimos del trabajo por todas sus observaciones]

${ }^{1}$ Cf. Pym, 1996.

${ }^{2}$ Acúdase, entre otros, a Solalinde, 1915; Menéndez Pidal, 1951.

${ }^{3}$ Fernández Ordóñez, 1999: 105-126, revisa varios puntos esenciales: que las escuelas alfonsíes trabajaron desde 1250 hasta la muerte del rey sabio; que, hacia 1270 , se gestó el proyecto concreto de redactar tanto la Estoria de España como la General Estoria; y que las dos obras recurren a las mismas traducciones de las fuentes (entre ellas, Plinio, Ovidio, Lucano, Pompeyo Trogo, Justino, Orosio, EusebioJerónimo, Sigeberto de Gembloux, Lucas de Tuy, Hugucio, Jiménez de Rada, etc.). De la misma estudiosa, véanse, asimismo, entre otros, 1989, 1992. Señalaré, entre muchos, dos estudios sobre la $G E$ : Lida de Malkiel, 1958-1959 y 1959-1960.

${ }^{4}$ Guyart des Moulins (1251-1322) publicó una versión de la Biblia en francés antiguo a finales del siglo XIII (1297). Se trata de la Bible historiale, que parte, no sólo de la Vulgata, sino también de la paráfrasis latina realizada por Pedro Coméstor, hacia 1170, en su Historia Scholastica. Precisamente, acerca de la GE como Biblia historial, véase Morreale, 1982.

${ }^{5}$ Respecto a las peculiaridades de la traducción en la GE, consúltese Rubio Tovar, 2014.

${ }^{6} \mathrm{La} G E$ traduce y comenta casi todos los libros canónicos de la Biblia.

${ }^{7}$ Hecha a partir del texto hebreo, no de la versión griega de los Setenta. Fernández Ordóñez, 1999: 119, subraya que la traducción de la Biblia se comentó, entre otras fuentes, con ayuda de la citada obra de Coméstor. Por mi lado, he comprobado que éste antropónimo es mencionado 633 veces en la parte que revisamos. 
fonsina, que, en dos códices, se conserva en la Biblioteca de El Escorial: abarca parte del Antiguo Testamento y casi todo el Nuevo.

De entre la $G E$, me concentraré en la Primera parte, donde se abordan los hechos bíblicos contenidos en el Pentateuco, desde la creación del mundo hasta la muerte de Moisés (Génesis-Éxodo-Levitico-Números-Deuteronomio). Como hemos indicado, además de la Biblia, los redactores de dicha parte recurrieron con frecuencia a las fuentes judías más destacadas, $\mathrm{y}$, asimismo, a las obras de numerosos autores griegos o latinos, entre otros.

1.2. Mi propósito es situar cronológicamente los autores griegos o latinos y sus obras mencionados en la indicada parte de la $G E$, y, a la vez, detenerme brevemente con algunas aclaraciones. La meritoria edición de la $G E$, única completa de la obra, aparecida en $2009^{8}$, presenta algunas veces los nombres de autores clásicos (especialmente griegos) con grafías que los hacen irreconocibles. Precisamente nuestra aportación quiere animar a la colaboración entre estudiosos hispanistas y clasicistas. En total recojo 32 autores griegos y 16 latinos, distribuidos en nuestra redacción, dentro de lo posible, siguiendo un orden cronológico descendente?. Veremos algunas deformaciones de varios antropónimos, especialmente de autores griegos, recogidos y aceptados en el útil índice de nombres propios de dicha parte de la $G E^{10}$.

1.3. En punto a las abreviaturas griegas y latinas he seguido un criterio mixto, para comodidad del lector no especialista. En general, recurro a las abreviaturas normales de los repertorios bibliográficos (hoy fácilmente localizables en la red), pero, en algunos casos, doy el título completo, si la obra no es muy conocida o no está incluida en los instrumentos generales.

\section{AUTORES DE LA LITERATURA GRIEGA}

Nuestra aportación, dentro de la parte estudiada de la $G E$, abarca escritores de la literatura griega desde el siglo VIII a. C. (periodo arcaico) hasta mediados del IV d. C. (periodo imperial).

${ }^{8}$ Alfonso X el Sabio, General estoria, Pedro Sánchez-Prieto (coord.), Madrid, Fundación José Antonio de Castro (Biblioteca Castro), 2009 (la Primera parte, en dos volúmenes había aparecido ya en 2001). Para esta contribución me atengo a la Edición de textos alfonsíes en Real Academia Española: Banco de datos (CORDE) [en línea], primera parte, por P. Sánchez-Prieto Borja - R. Díaz Moreno - E. Trujillo Belso. En las citas que doy aparecen tres datos: parte de la obra (en romanos), libro y capítulo (en cifras arábigas).

${ }^{9}$ Tras el nombre del autor doy entre paréntesis el número de apariciones dentro de la Primera parte de la $G E$.

${ }^{10}$ Cf. Almeida Cabrejas (2015), publicado a partir de la edición de Sánchez-Prieto y otros, aparecida en 2001, en la Fundación José Antonio de Castro y reeditada en 2009. Lo mencionaremos como «Índice». 


\subsection{HOMERo (2: HOMERo, OMERO)}

2.1.1. Su momento de esplendor suele situarse en los últimos decenios del VIII a. $\mathrm{C}^{11}$. En el corpus revisado contamos con dos menciones de ese autor. En el primer caso, a propósito de Etiopía, se nos dice: «E Omero, que fue muy grand sabio entre todos los griegos, afirma que verdaderamientre dos son las Etiopias ${ }^{12}[\ldots]$ e que allí se fazié un río que nace, así como vos contamos, del $\mathrm{Nilo}^{13}[\ldots]$ e llámanle Nigris $^{14}[\ldots] »^{15}$.

La $G E$ sigue en este punto a Plinio ${ }^{16}$, pero, a decir verdad, Homero no menciona nunca el corónimo Etiopía. En cambio sí ofrece siete referencias del gentilicio «etíope». No creo que el texto alfonsí pudiera haber tenido en cuenta el pasaje de $O d$. 1.22-23, donde, dentro del proemio del aedo, se cuenta que los dioses, todos menos Posidón, se compadecían de Odiseo, por los muchos años y sufrimientos que el héroe había arrostrado lejos de los suyos. En aquellos momentos, ese dios estaba entre los etíopes para celebrar una hecatombe de toros y carneros: «los etíopes, que viven en dos grupos, lejos de los hombres:/ unos donde Hiperión se hunde, otros, donde se levanta». Pensemos que Hiperión, uno de los Titanes, figura en Homero, ya como padre de Helio (Sol), ya como el propio Helio.

Por otro lado, de los autores griegos con obra conservada, los primeros en hablar de Aithiopía son Heródoto (11), Tucídides (1) y Eurípides (2).

2.1.2. La segunda mención alfonsí la hallamos en un contexto donde se nos ofrece una verdadera acumulación de fuentes. Efectivamente, a propósito de cómo nace el Nilo y los lugares por donde pasa, la $G E$ nos dice: «Del Nilo cómo nace e de los logares ó parece e por ó passa fablaron muchos sabios, assí como Aristótil e Tolomeo e Plinio, Eratesten e Homero ${ }^{17}$ e Temosten e Artemidoro e Esidoro e Muciano e Lucano e Paulo Orosio»" ${ }^{18}$.

Esta secuencia es de extremo interés para nuestro propósito a causa de los muchos autores mencionados, de los que iremos ocupándonos poco a poco. Revisando

${ }^{11}$ Acerca de su presencia en Alfonso X y en la GE, cf. Eisenberg, 1973; Saquero SuárezSomonte - González Rolán, 1993; López Férez, 1994; Casas Rigall, 1999, 1999a; Peláez Benítez, 1999; del Castillo Lebourgeois, 2015; Cristóbal, 2015; etc. pissa», 13 .

${ }^{12}$ Aparece 79 veces en la $1^{\text {a }}$ parte; además, nos da los gentilicios «etiopianos», 14; y «etio-

${ }^{13}$ El Nilo (167 citas en el corpus revisado) merece un estudio aparte.

${ }^{14} \mathrm{El}$ Nigris (6 secuencias en nuestro corpus). El primero en nombrarlo es Plinio, como Nigris (sc. fons): HN 8.77: Apud Hesperios Aethiopas fons est Nigris, ut plerique existimavere, Nili caput.

${ }^{15}$ GE I.11.39.

${ }^{16}$ HN 5.43: [...] verissima opinione eorum, qui desertis Africae duas Aethiopias superponunt, et ante omnes Homeri, qui bipertitos tradit Aethiopas, ad orientem occasumque versos.

${ }^{17}$ No aparece en Homero (Sí en Hesiodo: Th. 338), ni en Artemidoro. Sí en Aristóteles, Eratóstenes y Ptolomeo.

${ }^{18}$ GE I.5.7. La cita procede de Plinio, HN 5.47. 
los nombres citados, conviene advertir que el Nilo no aparece en Homero ${ }^{19}$. Sí en los demás escritores griegos (en orden cronológico, Aristóteles, Eratóstenes, Timóstenes, Artemidoro y Ptolomeo ${ }^{20}$, así como en los cinco latinos allí mencionados. Los veremos en el lugar oportuno.

\subsection{HesíOdO (1: EsIODO) $)^{21}$}

2.2.1. Para muchos cabe situar su periplo vital en fechas algo posteriores a las de Homero. En la GE sólo contamos una cita que plantea varias dudas. Con referencia al "saber de la astrología e de la geometría e de todos los saberes liberales», la $G E$ cita a Josefo: «Onde aduze Josefo por exiemplo ende a Manicón, que escrivió las estorias de los egipcianos, e a Beroso, que las de los caldeos, e a Maço, e a Esto, e a Jerónimo de Egipto, que escrivió la estoria de la cibdat Feniça, segund avemos dicho, e otrosí Esiodo e Agateo e Belenico e Acusilao e Efero e Nicolao. Todos estos fazen en sus estorias remembrança d'aquellos antigos cómo algunos d'ellos visquieron mil años, e algunos poco menos ${ }^{22}$.

Se trata de una cita tomada de Josefo, Antiquitates Iudaicae (AI), 1.108. Una traducción del texto griego puede ser la siguiente: «Pues también Manetón, el que hizo la descripción de los egipcios, y Beroso, el que compendió los asuntos caldeos, y Moco y Hestieo, y, además de ésos, Jerónimo el egipcio y los que describieron los asuntos fenicios concuerdan con lo dicho por mí, y Hesíodo y Hecateo y Helanico y Acusilao (Hêsíodós te kaì Hekataîos kâ̂ Hellánikos kaì Akousílaos), y, además de ésos, Éforo y Nicolao cuentan (historoûsi) que los antiguos vivían mil años (zếsantas été chília) ${ }^{23}$. Pero sobre ésos, que cada uno lo considere como le guste». Por lo que se refiere a Hesíodo el texto se considera dudoso, y es recogido por Merkelbach - West con el número 356, como perteneciente a los fragmenta dubia. Con todo, lo que nos ha llegado de Hesíodo no nos permite asegurar la afirmación de Josefo, recogida después en la obra alfonsí.

${ }^{19}$ Dentro de la literatura griega, los primeros en nombrar ese río son Hesíodo (Th. 338), Solón y el poema épico Danaide.

${ }^{20}$ Sobre ciertas deformaciones y alteraciones de algunos nombres propios dentro de la $G E$, hablaré más abajo.

${ }^{21}$ De su presencia en la GE se han ocupado López Férez, 2014; Almeida Cabrejas, 2016; Gómez Jiménez, 2018: 173-193; etc. [A partir de aquí recogeré las distintas formas en que aparece el antropónimo correspondiente a cada autor, cuando no coincide con la aceptada actualmente].

${ }^{22} G E$ I.2.7.

${ }^{23}$ Sobre «vivir mil años», aparte de los fragmentos pertenecientes a varios autores mencionados en la secuencia, las primeras referencias en obras conservadas las encontramos en la versión de los Setenta (Ec. 6) y en Diodoro de Sicilia (1.26.5). Para Hesíodo, consúltese Hesiodi Theogonia, Opera et Dies, Scutum, ed. F. Solmsen; Fragmenta selecta, eds. R. Merkelbach - M.L. West, Oxford Classical Texts, 1970. 
Si acudimos a Josefo vemos que, en contraste con dicho pasaje de la $G E$, Agateo es Hecateo, y Belenico, Helanico, recogidos sólo aquí en el corpus alfonsí revisado. El pasaje de Josefo tuvo alguna recepción favorable. Así, en nuestro siglo IV, Eusebio de Cesarea, dentro de su Praeparatio evangelica (9.13.5, donde, por error, leemos Mólos en vez de Môchos) recoge la cita de Josefo; también la ofrece Jorge Sincelo (siglos VIII-IX), en su Ecloga chronographica, p.44.15. Por su parte, Juan Lorenzo «el Lidio» (Ioannes Laurentius Lydus) (490- ¿), en su tratado De mensibus (3.5), cuenta que Hesíodo, Helanico, Acusilao, Hecateo, Éforo y Nicolao se habían ocupado de los que vivían más de mil años.

Parte de los errores de transcripción de la $G E$ se deben a que el texto latino (cf. el ofrecido en The Latin Josephus Project) ya contenía importantes desviaciones respecto a la grafía griega. Así, en el texto latino correspondiente a Josefo, $A I$ 1.107, leemos: Nam et manathon qui descriptionem fecit aegyptiorum, et berosus, qui chaldeica deflorauit, et modius et aestius, ad haec et hieronimus aegyptius, qui phenicam [ph....em] disposuerunt, concordant cum meis dictis. Isiodorus quoque et egatheus et hellanicus et accusilaus, et inter hos ephorus et nicholaus in istoriis suis memoriam faciunt antiquorum, annis mille uiuentium. De his itaque sicut singulis gratum est ita cosiderent. Es decir, al griego, transcrito, Manéthōn, le corresponde Manathon; con Berosus, no hay problema; pero lo que serían las transcripciones griegas de Môchos y Hestiaîos, se les representa en latín como Modius, Aestius. Por tanto, los colaboradores del equipo, al leerlas y adaptarlas para incluirlas en el texto castellano, multiplicaron sin duda los errores.

Conviene insistir en las deformaciones de varios antropónimos, que, en ocasiones, son recogidos y aceptados en el meritorio y útil «Índice de nombres propios de la Primera parte de la General Estoria» ${ }^{24}$, ya citado y del que haré otras referencias. Baste ahora con insistir en que la lectura «Manicón» es Manetón; «Maço», Moco (de Mochus); «Esto», Hestieo; «Esiodo», Hesíodo; «Agateo», Hecateo; «Belenico», Helanico; «Efero», Éforo. Por su parte, Beroso, Jerónimo de Egipto, Acusilao y Nicolao no presentan problemas con la grafía tal como aparecen en la $G E$. Hablaremos más sobre estos nombres.

2.2.2. Las otras tres secuencias de "Esiodo» ${ }^{25}$ presentes en la $G E$, parte primera, no sé si pudieran tener alguna relación con el antropónimo «Esiodoro» (citado seis veces en la Primera parte de la $G E$ ), una de cuyas secuencias lo hace autor de una glosa referente a la Biblia, presente en el Libro de las noblezas y maravillas de Roma (Cf. $G E$ I.3.8).

${ }^{24}$ Cf. Almeida Cabrejas, 2015.

${ }^{25} G E$ I.20.35 (tres veces; donde se alude a «Esiodo en la glosa»), hablando de la lana. En la segunda aparición leemos ( GE I.20.35) «Otrossí aduze allí Esiodo otro exiemplo de la mezcla de la lana e del lino en que diz assí: la mugier fuert falló lana e lino, e obró d'ello con sus manos cosa provechosa». No puedo aportar más indicaciones sobre quién es ese "Esiodo» de la glosa, pero sí me inclino por pensar que no es el mismo antes tratado, contra lo que sugiere el «Índice», p. 313. Sobre «Esiodoro», cf. nota 294. 


\subsection{Tales de Mileto (1)}

Vivió aproximadamente entre 624-546 a. C. A propósito de la Osa Menor, y tras haberse mencionado poco antes a Ovidio, leemos: «Dize otrossí esse esponedor $^{26}$ que aquello por que la menor Ossa á nombre Fenice que se deve esto catar que ovo ella aquel nombre segund era llamado aquel que la primero figuró en el cielo, e éste fue un sabio a que dixieron Melesio Tales, que fue de Filoseo, e esto es de Mileo, que era una cibdad de Fenicia que avié assí nombre. E este Milesio Tales figuró peró que otra estrella era en el cielo la menor Ossa, e porque era él de Fenicia dixieron a la menor Ossa Fenice e Fenicea, ca a la mayor Ossa los griegos la avién ya figurada $»^{27}$. Un punto no resuelto todavía es de qué comentarista («esponedor») se está hablando aquí. Puede tratarse de Juan de Garland o Garlandia («el inglés»), nacido en Inglaterra a fines del XII, el cual estudió en Oxford, y, posteriormente, explicó gramática, retórica y léxico en Toulouse y París; dentro de sus obras figuran los populares e influyentes Integumenta super Ovidium Metamorphoseos, aparecidos hacia 1234, de carácter alegórico y simbólico. Pero también puede aludirse aquí al calificado en la $G E$ como el «freire», a saber, Arnulfo de Orleáns, que, en el siglo XII, vivió en torno a dicha ciudad, y publicó unas Allegoriae super Ovidii Metamorphosin de notable influencia en la literatura medieval. Éste, en la $G E$, es más importante que el anterior, y aparece doce veces en la primera parte de la obra y treinta y ocho en la segunda. Ante algunos comentarios de los mencionados, puede verse la crítica de la misma respecto a ciertas metamorfosis presentes en los relatos míticos:

D'aquellos mudamientos que dixiemos de Parrasis de virgen en non virgen o de casta en non casta, e de non virgen o non casta en preñada, e de preñada en paridora de fijo, como quiere que verdaderamientre sean mudamientos éstos e lo digan assí los sabios, el freire e maestre Joán ell inglés, que esponen los dichos de Ovidio, peró dezimos que non son mudamientos éstos que otro esponimiento ayan mester nin otra allegoría, ca estoria e verdadera es e cosa natural, e que veemos que contece cada día en las yentes por las mugieres ( $G E$ I.21.16).

En lo tocante a la relación de Tales con la Osa Menor tenemos algunas noticias gracias a un fragmento que nos ha llegado de la Isagoge ad Arati Phaenomena, procedente de Aquiles Tacio (si es el mismo que el autor de la novela erótica Leucipa y Clitofonte, obra de fines del II d. C), en que se indica que Tales había descubierto el Carro Menor (sc. la Osa Menor), y que por ello Calímaco había afirmado que

${ }^{26}$ Salvo García, 2012a, expone las dificultades para precisar de qué fuente (una o más) parte la $G E$ para un relato extenso y complicado en que también se aborda el mito de Icario. En la elaboración y distribución de éste, la estudiosa ha mostrado la influencia de una obra anónima, el Liber de natura deorum, breve manual mitográfico, conservado en un manuscrito inglés del siglo XIV.

${ }^{27}$ GE I.21.14. 
«navegó hacia Mileto, lo que fue una victoria/ de Tales, que, acertado en su opinión también en las demás cosas,/ se dice que tomó en consideración del Carro Menor/ las estrellitas por el que los fenicios navegan». En el pasaje alfonsí hay un error de bulto al indicar que "Mileo» (es decir, Mileto) era una ciudad de Fenicia, seguramente con el deseo de convertir a Tales en un nacido en Fenicia.

\subsection{Helanico (1: Belenico)}

Logógrafo cuyo momento culminante tuvo lugar hacia el 500 a. C, llamado «de Lesbos» (o «de Mitilene»), brilló hacia el 500 a. C. La GE en la $1^{\text {a }}$ parte lo cita sólo una vez, pero con una grafía deformada y casi irreconocible, a saber, como Belenico $^{28}$. Véase apartado 2.2.1. La cita de Josefo allí indicada, consta también en Helanico como Fr. 202.

\subsection{Acusilao (1)}

Acusilao de Argos fue un logógrafo y mitógrafo griego que en torno al 500 a. C. escribió tres libros de genealogías de los que nos han llegado algunos fragmentos. Véase apartado 2.2.1. Respecto a la cita de Josefo, el TLG la registra también dentro de Acusilao, como Fr. 46.

\subsection{EURÍPIDES $(1)^{29}$}

El más joven de los tres grandes tragediógrafos atenienses vivió entre los años 484-406 a. C. En la GE, hablando de Atlas, hermano de Prometeo, con respecto a que llevaba sobre sí todo el cielo, se nos dice:

Sobresto dize un sabio que ouo nombre Euripides, segund cuenta Eusebio e Jheronimo, que en Affrica a un mont muy alto ademas e quel dizien otrossi el mont Athlant; e tan bien daquello que dixieron del rey Athlant como daquel mont muy alto, fablaron mucho los auctores delos gentiles en muchos logares en sus libros, como Ouidio, e Virgilio, e Estacio e Oracio e otros; onde uos queremos en este logar, por esta razon, contar daquel mont Athlant unas razones que fallamos dichas de Plinio e de otros sabios quales razones e quan estrannas oyredes agora aqui ${ }^{30}$.

${ }^{28}$ Así, en Índice, 2015.

${ }^{29}$ Del lejano reflejo de Eurípides en la GE se han ocupado Gómez Fariña, 2014; Cristóbal, 2015; Lauriola - Demetriou, 2015: 511; López Férez, 2015; etc.

${ }^{30} G E$ I.10.21. El TLG nos proporciona tres citas de Atlas en las obras euripideas: Hipp.747, $H F 405, I o$. 1. No obstante la GE parece haber tomado la referencia de la Historia de todas partes (con transcripción del griego, Pantodapè historía) de Eusebio de Cesarea, dividida en dos partes: la Cronografía, 
Como se ve, si hasta ahora la fuente esencial ha sido Josefo, en este texto se acude a Jerónimo, que, a su vez, se basa con frecuencia en Eusebio.

\subsection{Platón (5: Platón, 1; Plato, 4)}

La vida del filósofo suele enmarcarse entre los años 427-347 a. C. En la parte estudiada de la $G E$ lo hallamos cinco veces ${ }^{31}$. En la primera lo leemos a propósito de las palabras dirigidas por César al obispo Acoreo ${ }^{32}$ : «E dinos esto e manifiéstanos en todo lo que es, e muéstranos los dioses que más quieren ser conocidos de los omnes e onrados d'ellos, e si verdad es lo que fallamos escrito que los tus mayores enseñaron las sus cosas santas a Platón de Atenas el filósofo, enseña tú a mí esto ${ }^{33}$ ॥4 $^{34}$.

Las otras cuatro aluden a la presencia de la peste dentro de la obra platónica ${ }^{35}$. En el apartado 2.20.1 volveremos sobre este punto.

\section{8. ÉFORO (1: EFERO)}

Éforo de Cime (aprox. 400-330 a. C.) fue un historiador griego conocido especialmente por su historia universal en 29 libros, de los que sólo nos han llegado fragmentos. En la citada obra se abarcaba desde los años míticos de los Heraclidas (sc. los hijos y sucesores de Heracles) hasta el 340 a. C. En la GE lo leemos como Efero: acúdase al apartado 2.2.1.

resumen de historia universal, y los Cánones cronológicos, donde los datos históricos se ofrecían en columnas paralelas. Esta parte fue conservada por Jerónimo y se le da, por lo general, el título de Chronicon. En éste (pp.50-51) leemos así: Atlas frater Promethei praecipuus Astrologus dictus est, qui ob eruditionem istius disciplinae etiam coelum sustinere affirmatus est. Euripides autem montem esse altissimum dicit, qui Atlas vocetur. Por su lado, Jorge Sincelo, cronista y eclesiástico bizantino (murió hacia el $810 \mathrm{~d}$. C.), en su Ecloga chronographica (p.175) se hace eco de la relación entre Eurípides y el monte Atlas. El orónimoteónimo lo hallamos también en Virgilio, Eneida 1.741, 4.481, 6.796, 8.136.140.141; Ovidio, Met. 2.296, 6.174; etc. Véanse, asimismo, Horacio, Carmina 1.10.1; 1.34.11; Estacio, Tebaida 1.98; 5.430; 7.4; 8.315; Silvae 1.1.60; 4.2.19; 4.3.157; etc.

${ }^{31}$ Sobre el reflejo del filósofo en Alfonso X, y, de modo especial, en la GE: Lida de Malkiel, 1959-1960; Rico, 1972: 137; Eisenberg, 1973; Alvar, 2010: 289, 377; Taylor, 2015; etc.

${ }^{32}$ Personaje mencionado por Lucano, $B C$ 8.475; 10.193. Era el sacerdote que, en Menfis, controlaba las crecidas del Nilo.

${ }^{33}$ Cf. Lucano, $B C$ 10,179-183. La $G E$ ofrece casi una traducción de la secuencia.

${ }^{34} G E$ I.5.10. El texto apunta a un tema de gran importancia: cómo los saberes egipcios pasaron a Grecia gracias a Platón. Por limitarme al corónimo, transcrito Aégyptos, diremos que ya está bien documentado en Homero (10 presencias), y que sería Heródoto quien lo recogiera con gran frecuencia (253 apariciones). Por su lado, Platón lo muestra en 20 lugares.

${ }^{35} G E$ I.13.4, I.13.14, I.13.15, I.13.20. 


\subsection{ARISTÓteles (11: ARISTÓtIL, 10; ARISTOTÓTIL, 1) $)^{36}$}

Ya hemos visto al filósofo (384 a. C.-322 a. C) como una de las autoridades que se habrían ocupado de dónde nació el Nilo y por dónde pasa ${ }^{37}$. Realmente, hallamos 34 menciones de dicho río en el estagirita, el cual aborda diversos aspectos relacionados con el mismo, interesándose, por ejemplo, por sus crecidas y desembocadura en el Mediterráneo.

En otro lugar la $G E$, al ocuparse de cómo Abrahán supo qué era Dios, recurre al filósofo cuando establece una cierta semejanza entre el hombre y dios; aquél, como participante en la gloria de éste ${ }^{38}$.

A su vez, en la $G E$ advertimos un interés manifiesto por los cruces sexuales de animales distintos ${ }^{39}$. Se recurre a Plinio ${ }^{40}$, que tomó los datos a partir de Aristóteles, y, asimismo, de otros muchos sabios, sin especificar. Se nos cuenta que el estagirita, por petición de Alejandro, estuvo estudiando durante mucho tiempo las naturalezas de los animales y que compuso 50 libros $^{41}$ con los resultados, de donde se nutre especialmente Plinio. Un detalle importante ofrecido por la $G E$ (I.20.9) es que, en ocasiones, la leona se une al leopardo y tiene descendencia, pero el león lo advierte y despedaza las crías; también, por el olor, aquél advierte la relación sexual mantenida por la leona, pero ésta procura lavarse bien para evitar dicho olor, y, con todo, sigue al león a lo lejos.

${ }^{36}$ En torno al reflejo de Aristóteles en Alfonso X, y, ante todo, en la $G E$, acúdase a Rico, 1972: 122 (éste señala que la primera frase de la $G E-«$ Natural cosa es de cobdiciar los omnes saber los fechos que acaecen en todos los tiempos»- se basa en un texto muy conocido del estagirita, Metafisica, 980a21. En dicho lugar leemos: Pántes ánthrōpoi toû eidénai orégontai phýsei, «Todos los hombres desean saber por naturaleza»), 126, 144, etc.; Montoya, 1995; Alvar, 2010: 289, 377; Cristóbal, 2015; Pérez Herranz, 2016: 74, 108 (se ocupa de la leyenda del llamado «Aristoteles hispanus», asunto bien tratado en Rico, 1967), 282, etc;

${ }^{37}$ Véase nuestro apartado 2.1.2.

${ }^{38} G E$ I.4.32. Hallamos en el estagirita notables secuencias donde se establecen las diferencias entre el «hombre» (ánthrōpos) y el «dios» (theós): cf., por ejemplo, EN 1123a7; 1145a21; 1178b24; etc.

${ }^{39} G E$ I.20.9. En el capítulo se menciona siete veces al filósofo, verdadera acumulación del antropónimo: seis con la forma Aristótil, y una, Aristotótil.

${ }^{40} H N 8.16$.

${ }^{41}$ En la GE I.20.9 se habla de un pasaje de Plinio donde se trataría de un escrito de Aristóteles, con cincuenta libros, dedicado a los animales. El citado pasaje alfonsí apunta sobre el estagirita que "fizo de las naturas de las animalias L $\mathrm{L}^{\mathrm{a}}$ libros, e dend tomó Plinio esto» (Lo comprobamos en el naturalista (HN 8.44): quos percunctando quinquaginta ferme volumina illa praeclara de animalibus condidit). Posiblemente el romano, para sostener dicho número, habría tenido en cuenta todos los tratados aristotélicos dedicados a la Historia natural e incluso algunos no transmitidos en que se abordaban diversos aspectos de anatomía comparada, libros perdidos para nosotros. Desde luego la Historia animalium del filósofo tiene ahora diez libros. Si los sumamos a todos los títulos precisados por el genitivo latino animalium («de los animales»), teniendo en cuenta también los libros de que aquéllos están compuestos, tendríamos un total de 21 libros, cifra todavía lejana de los cincuenta citados por el naturalista romano. 
Por último, la obra alfonsí nos dice que el alma tiene tres facultades (poderes): «Tres poderes á ell alma, assí como lo nós aprendimos por palabras de Aristótil e de Plinio e de Augustín e de Orígenes e de Dionís ${ }^{42}$ e d'otros muchos que lo cuentan por ellos» ${ }^{43}$.

\subsection{Hecateo (3: Ecateo, 1; Etateo, 1; Agateo, 1)}

El llamado «de Abdera» o «de Teos», historiador griego del siglo IV (no debemos confundirlo con el homónimo «de Mileto», historiador y geógrafo de fines del VI y comienzos del v). Contemporáneo, más o menos, de Alejandro Magno, acompañó a Ptolomeo I en varias ocasiones, en una de las cuales viajó con él por el Nilo, río arriba. Fue autor de unos Egipciacos, o relatos referentes a Egipto, conocidos sólo por fragmentos. Según Josefo, que lo cita en 10 ocasiones, fue autor también de un libro relativo a los judíos, muy discutido. Un error importante de la $G E$ es afirmar ${ }^{44}$ que ese relato se habría escrito en árabe, y que ( $s c$. los redactores) no habían encontrado una traducción del mismo al latín. Nótese el gusto de la $G E$ por esos relatos y su afán por hallarlos. En otra cita se dice que dicho Hecateo era caldeo, cuando la realidad es distinta. Cuando la $G E$ lo relaciona con Caldea podríamos deducir que los redactores hubieran pensado que de allí era el autor del mencionado escrito a propósito de los judíos, los cuales, en tiempos pretéritos, habían vivido en dicho país.

Veremos que la $G E, 1^{\text {a }}$ parte, lo recoge ${ }^{45}$ bien como Agateo ${ }^{46}$, bien como Ecateo, o como Etateo. Respecto a Agateo, véase nuestro apartado 2.2.1. He aquí las otras dos citas: «Otrossí diz Josefo que Ecateo, uno d'essos sabios d'aquella tierra, que fizo su remembrança grand e buena de Abraham, e que cumplió ý más, que escribió toda la estoria de Abraham, e compuso ende libro que dexó fecho. E este libro non fallamos quel ayamos trasladado los latinos del arávigo en lo nuestro» ${ }^{47}$. Y, además: «Otrossí Etateo, que fue otro sabio de Caldea que escrivié las estorias d'aquella tierra e los

${ }^{42}$ Dionisio el Exiguo (aproximadamente 470-544), monje erudito y matemático del siglo VI, inventor de la expresión anno Domini («año del Señor») para calcular la fecha de la Pascua. Contamos con cinco referencias del mismo en la primera parte de la $G E$, donde en tres ocasiones se le llama «el Abad Dionís». Dionisio (en latín Dionysius Exiguus, entendido por unos como «Humilde», y, por otros, como «Enano»), trabajó primero en un monasterio de Tomi (actual Constanza, en Rumania), y, luego, en la curia de Roma, donde tradujo muchos libros del griego al latín y llegó a ser un experto en la ley canónica. Varias de sus obras en latín están recogidas en el volumen 67 de la Patrologia latina.

${ }^{43}$ GE I.20.35. Respecto a Aristóteles, precisemos que en de An. (Sobre el alma) 2.2.413b, se habla de las distintas facultades (o potencias) del alma: facultad nutritiva, sensitiva, discursiva y movimiento.

${ }^{44} G E$ I.4.8.

${ }^{45}$ Sobre la presencia de dicho historiador en la $G E$, véase, entre otros, López Férez, 2014.

${ }^{46}$ Así, en Indice, 2015, sin relacionarlo con Hecateo; dicho instrumento se interroga, en cambio, si Etateo corresponde a dicho antropónimo.

${ }^{47} G E$ I.4.8. 
fechos que ý acaecieron, fabla otrossí de Abraham, e fizo ya más que los otros, que compuso ya de Abraham un libro que dexó escrito» ${ }^{48}$.

Los fragmentos de dicho Hecateo han sido muy discutidos y estudiados (cf. Bar-Kochva, 2010) porque para algunos fue el primer griego que se ocupó de los judíos y, en concreto, de Abrahán.

\subsection{TeOFRASTO (1: TeORASTO)}

Su vida transcurrió en los años 371-287 a. C. Director del Liceo a la muerte de Aristóteles, quien lo nombró para el cargo, fue autor de una obra amplísima, mal transmitida. Sus obras de botánica pueden ser quizá lo más relevante de lo conservado. En la $G E$, parte revisada, lo tenemos como «Teorasto», mencionado a propósito de los resultados de la mezcla sexual de los animales, un punto al que se le confiere especial importancia en la obra alfonsí. Leemos así: «Teorasto el sabio fizo creer al pueblo, segund retrae Plinio, que en Capadocia que las mulas paren, e que se son allí de su natura e non d'otra ${ }^{49}$. Pasaje donde hallamos otras informaciones curiosas, como que el mulo o la mula que dan coces se calman si los hartan de vino; y, además, que, en una ocasión, una yegua, de su unión con un mulo, quedó preñada y tuvo un mulo pequeño, según Plinio. Éste menciona en 44 ocasiones al estudioso griego, el cual estuvo siempre muy atento a numerosas cuestiones de historia natural.

\subsection{Beroso (5)}

Llamado por los griegos «de Caldea» (o «de Babilonia»), Beroso vivió quizá en los años 350-270 a. C.; escribió en la koiné griega y fue autor de unos Caldaicos en tres libros: en ellos abarcaba desde los orígenes de Babilonia hasta el reinado de Antíoco I (monarca del imperio Seléucida en los años 281-261 a. C.). Se le atribuyen otras obras, pero espurias para muchos. Su legado literario fue importante durante el periodo helenístico, pero sólo nos han llegado unos treinta fragmentos. En cambio, numerosos escritores griegos nos han transmitido noticias sobre el citado: Josefo (12),

${ }^{48} G E$ I.4.14. En Josefo, $A I 1.159$ se indica que «Hecateo, al hacer mención (de Abrahán), hizo algo más, pues, tras componer un libro sobre él, lo transmitió».

${ }_{49}^{49} G E$ I.20.26. No conservamos el pasaje teofrasteo en que se basara el naturalista romano. Efectivamente, si nos han llegado varios de sus trabajos sobre botánica, se ha perdido casi toda su producción referente a zoología. El título de uno de sus tratados dedicados al mundo animal era Sobre los animales (en siete libros). Por su posible interés recojo la cita de Plinio, HN 8.173: idcirco mulas non parere. est in annalibus nostris peperisse saepe, verum prodigii loco habitum. Theophrastus vulgo parere in Cappadocia tradit, sed esse id animal ibi sui generis. mulae calcitratus inhibetur vini crebriore potu. in plurium Graecorum est monumentis cum equa muli coitu natum quod vocaverint $<g>$ innum, id est parvum mulum. 
Aetio doxógrafo (3), Eusebio (11), Estobeo (3), Jorge Sincelo (17), etc. No nos corresponde, en cambio, hablar del Pseudo-Beroso, al que se le atribuye un famoso escrito falsificado por Anio de Viterbo en 1498. Éste, con referencia a España, inventó una lista de reyes que remontaban hasta Túbal, hijo de Jafet, un hijo de Noé.

La $G E$, en la parte abarcada por esta aportación, lo recoge en cinco pasajes $^{50}$. En la $G E$ se le nombra, por ejemplo, con referencia al arca de Noé: «E los sos sabios que escrivieron en su tierra las estorias de los fechos que ý acaecieron fablaron d'este diluvio e d'esta arca en sus leyendas bárbaras, e assí lo otorga Josefo. E fue ell uno de los escrividores d'estas estorias Beroso el caldeo, e llama naf a esta arca de Noé. E dixo ende assí d'aquella naf que vino en Armenia e posó cerca'l mont Cordiceo, e que aun á ý d'ella, e que algunos van allá por d'aquel bitumen con que ella fue untada, que es muy bueno pora lavar e toller toda manziella de quequier ${ }^{51}$. Y, asimismo, en otro lugar: «E d'esta guisa fablaron d'este diluvio e del arca Beroso de Caldea e Jerónimo de Egipto, e Manaseas de Damasco" ${ }^{52}$. Este pasaje lo veremos con más extensión en Mnaseas: apartado 2.16. Acúdase asimismo a otro lugar, ya visto: cf. 2.2.1.

También se le menciona dos veces a propósito de Abrahán. En la primera se nos dice así: «E Josefo aun por aforçar sus razones aduze sobr’ellas estas pruevas de los arávigos que escriven del arávigo las estorias en aquella tierra ó moravan Tare e Abraham e sus compañas. E cuenta assí que Beroso el caldeo, que fue omne sabio, e que escrivió las estorias de los caldeos, que diz assí de Abraham nol nombrando: después del diluvio, en la dezena generación, fue entre los caldeos un varón justo e grand, e provado en las cosas e en los fechos celestiales $»^{53}$. Y, en la segunda, lo siguiente: «E Josefo en razón de pruevas d'esto que dixo Abraham diz en el seteno capítulo del primero libro de la Antigüedat de los judíos, e trae por testigos los sabios caldeos que fablaron del saber de Abraham. Onde Beroso, que fue ell uno d'ellos, nol nombró a Abraham por su nombre, mas dixo assí d'él: 'Después del diluvio, en la dezena generación, fue entre los caldeos en Caldea un varón justo e grande, e muy provado en las cosas celestiales e en los fechos d'ellas' ${ }^{54}$.

\subsection{MANETÓN (1: MANICÓN)}

El citado suele fecharse entre 323-250 a. C. Fue un sacerdote egipcio que vivió en la época de los dos primeros Ptolomeos y escribió en griego unos Egipciacos (Aigyptiakâ), en los que recogió la cronología de las diversas dinastías desde los comienzos

${ }^{50}$ Algunos estudios se han referido a la presencia de Beroso en la GE: Eisenberg, 1973; González Díaz, 2014: 74-78; López Férez, 2014; etc.

${ }^{51} G E$ i.1.6. Cf. Josefo, $A I 1.93$.

${ }^{52} G E$ I.2.6.

${ }^{33} G E$ I.4.8. Véase Josefo, $A I 1.158$.

${ }^{54} G E$ I.4.14. Josefo, $A I 1.158$. 
hasta Alejandro Magno. Esa obra histórica nos es conocida sólo de forma fragmentaria gracias a Josefo y otros historiadores.

En la sección revisada de la $G E$ consta sólo una vez, como Manicón ${ }^{55}$ : cf. apartado 2.2.1.

\subsection{Timóstenes (2: Temosten, Temostem)}

Timóstenes de Rodas, geógrafo griego de las primeras décadas del siglo III a. C., trabajó al servicio de Ptolomeo II Filadelfo, y escribió una obra titulada Sobre los puertos, en diez libros, perdida para nosotros ${ }^{56}$.

La GE, en el corpus revisado, lo presenta como Temosten ${ }^{57}$ (ya visto en el apartado 2.1.2) y Temostem, como ahora leeremos: «Sobr' este departimiento cuenta Plinio en el dozeno capítulo del quinto libro de la Natural estoria ó éll e estos otros sabios Temostem, e Eratostem, e Artenidor e Esidoro fablan de Egipto cuamaña es e cómo tajada segund que el río Nilo la fiende e la cerca» ${ }^{58}$.

\subsection{Eratóstenes (2: Eratostem, ERATesten)}

Natural de Cirene (276-195/194 a. C), gran sabio de conocimientos universales (matemáticas, astronomía, geografía, música, métrica, mitología, etc.), fue Director de la Biblioteca del Museo de Alejandría. En esta ocasión nos interesan ante todo sus Geográficos en tres libros, perdidos casi por completo, en que estudiaba el mundo entonces conocido. Se le tiene por fundador de la Geografía, de tal modo que buena parte de su terminología dentro de esa materia sigue todavía en uso. Con respecto a las menciones de la $G E$ en la parte revisada, Estrabón y Proclo nos ofrecen, cada uno de ellos, dos testimonios de la relación de Eratóstenes con el Nilo. Además, según datos ofrecidos por el TLG, otros siete contextos de autores varios nos permiten ver el interés de dicho sabio por Egipto.

La $G E$, sección estudiada, lo presenta con las grafías Eratesten ${ }^{59}$ (apartado 2.1.2), y Eratostem (apartado 2.14).

${ }^{55}$ Así, en Índice, 2015.

${ }^{56}$ Véase Estrabón, 9.3.10. Por lo demás, éste lo nombra en otras ocho ocasiones. Por algunos testimonios facilitados por el TLG (Hiparco de Rodas, Dídimo, Harpocración, etc.) puede afirmarse que Timóstenes estuvo, escribió y trabajó como geógrafo en Egipto. En él pudo basarse Plinio para citarlo en relación con dicho país. na entre sí.

${ }^{57}$ Tanto este antropónimo como el siguiente figuran en Índice, 2015, que no los relacio-

${ }^{58} G E$ I.7.7. Plinio, $H N$ 5.47, es aquí la fuente de la Estoria.

${ }^{59}$ Esta denominación y la siguiente las ofrece el Índice, 2015, donde no se las conecta. 


\subsection{Mnaseas (2: Manaseas, Maniseas) ${ }^{60}$}

Parece tratarse de Mnaseas de Patara (o Patras) (Mnaséas ho Patreús), que fue discípulo de Eratóstenes, en Alejandría, vivió hacia fines del III a. C. y escribió un Periplo sobre Europa, Asia y África, en seis u ocho libros, así como unos Oráculos con respuestas comentadas. Sólo nos han llegado escasos fragmentos ofrecidos por el TLG. Sus escritos no tenían una orientación historicista, sino que abundaban en elementos fantasiosos o claramente falsos. Lo citan, entre otros, Pausanias, Ateneo y Focio.

En la parte estudiada de la $G E$ lo leemos con dos grafías diferentes dentro del mismo contexto: Manaseas y Maniseas:

Otrossí Jerónimo de Egipto, que escrivió la estoria de la Antigüedat de Feniça, la cibdat de Egipto que pobló Feniz, hermano de la reína Europa e del rey Cadmo, e fijo del rey Agenor, fabló otrossí del fecho d'este diluvio e d'esta arca, e otrosí Maniseas de Damasco en el LXXXX ${ }^{\mathrm{a}} \mathrm{II}^{\mathrm{o}}$ libro de sus estorias dixo d'esta arca assí: un mont muy alto á en tierra de Armenia sobre tierra de Numiada, e el mont á nombre Baris. E a este monte dizen que fuxieron muchos sobre Numiada e se libraron allí del periglo de la muerte del diluvio general, e vino ý otrossí uno aducho en una arca, e posó con ella en somo lo más alto del mont Ocile, e allí fincaron mucho tiempo las remasajas de los maderos d'aquell arca, e aun éste fue aquel de quien Moisén, que dio la ley de los judíos, fabló en su estoria e lo escrivió. E d'esta guisa fablaron d'este diluvio e del arca Beroso de Caldea e Jerónimo de Egipto, e Manaseas de Damasco ${ }^{61}$.

El texto se basa esencialmente en Godofredo de Viterbo, Pantheon pars $2.82^{62}$. Pues bien, contrastado el texto alfonsí con el de Godofredo, hay curiosas diferencias: «sobre tierra de Numiada», es allí, super Miliadam; el monte Baris (bien recogido en la GE; Báris en Josefo), se llama allí Paris. A su vez, el texto del Pantheon está basado en Josefo, $A I$ 1.94, donde leemos para la primera frase hypèr tè̀n Minyáda (no obstante, parece que habría que leer Milyáda, corónimo asiático registrado desde Heródoto (1.173) y en varios autores posteriores). En Josefo, se alude en ese pasaje, a «Jerónimo

${ }^{60}$ Sobre su presencia en la $G E$, cf. Eisenberg, 1973.

${ }^{61} G E$ I.2.6.

${ }^{62}$ Es una especie de prólogo en Godofredo de Viterbo, Pantheon (lo he consultado en Rerum Germanicarum Scriptores Aliquot Insignes..., 2. p. 61). Dicho autor (1120-1202: en alemán original Gottfried von Viterbo, en francés antiguo Godefroi de Viterbe, y latinizado Gotifredus o Godefridus Viterbiensis), nacido en Viterbo, pero formado en Alemania, trabajó muchos años como secretario de los emperadores Conrado III, Federico I Barbarroja y Enrique VI. Se le otorgó el dominio de su ciudad natalicia y allí estuvo muchos años hasta acabar en 1191 su obra más importante, el Pantheon, un escrito sobre el mundo, especie de crónica universal desde Adán hasta el año 1186, compuesto en prosa y verso latinos, muy utilizado en la General Estoria, y lleno de hechos fabulosos y legendarios. Las obras del citado pueden encontrarse tanto en el tomo 198 de la Patrología Latina de Migne como en los Monumenta Germaniae historica: Scriptores, XVII. 
el egipcio, el que escribió sobre las antigüedades fenicias, y Mnaseas y otros muchos, y Nicolás Damasceno». De modo que no se indica nada sobre Mnaseas «de Damasco». (Hechas las comprobaciones posibles, el TLG no ofrece ninguna conexión entre Mnaseas y Damasco, ni tampoco con los distintos adjetivos relacionados con esa ciudad). En cambio en el Pantheon, sí lo leemos así: Item Manasseas Damascenus in libro Historiarum suarum octuagesimo septimo de eadem causa dicit. Est et super Miliadam excelsus mons in Armenia, qui Paris appellatur, ad quem multos fugientes novimus a diluvio liberatos.

Creo, pues, que tanto el calificativo de «Damasceno» como la referencia al libro 87 de sus Historias son datos que proceden del Pantheon, de donde los tomó directamente la GE. A su vez, el $T L G$ ofrece el texto de Josefo, como Mnaseas, Fr. 33; y, además, lo registra en Eusebio, PE 9.11.3, Onomast., p.4.15, y en Zonaras, Epitome historiarum, vol. 1, p. 21, línea 1.

\subsection{Polibio (4)}

El gran historiador griego de época helenística vivió en los años 200-118 a. C. Plinio lo cita 13 veces en su Historia Natural, fuente importantísima para la GE en la parte que he revisado. Veamos las dos citas, con dos menciones cada una. La primera alude al monte Atlas y el río Anatis:

Otrossí fallamos que después d'esto en el tiempo que Emilio Scipión ${ }^{63}$ de Roma andava por África conquiriéndola que tomó a Polibio, que escrivié estonces los fechos de los romanos cuando fazién los libros a que llamavan annales, de los fechos de cada año el suyo, e diol navíos e todo guisamiento e mandól que andidiesse toda África enderredor por agua e que escodriñasse d'aquella part las oriellas de la mar e sopiesse qué cabos avié aquella tierra. E Polibio fue, e desque lo vío todo e lo fue poniendo en escrito fabló ý de los términos d'aquel mont e del logar ó es. E departe otrossí por mostrar aquellos términos que d'aquel mont Atlant contra occident que yazen unas sierras llenas siempre de bestias fieras estrañas que se fazen en África, e duran estas sierras con sus sotos fasta'l río a que dizen Anat ${ }^{64}$.

${ }^{63}$ Publio Cornelio Escipión Emiliano, llamado Africano Menor Numantino (185-129 a. C.), jefe supremo de la Tercera Guerra Púnica, destructor de Cartago, y, luego, vencedor de los numantinos tuvo desde siempre gran amistad con Polibio, que le acompañó en varias de sus expediciones militares.

${ }^{64} G E$ I.10.25. Véase el pasaje de Plinio, HN 5.9-10, donde el historiador habla del viaje exploratorio de Polibio por las costas occidentales de África, cuando Escipión Emiliano estaba en ese continente al frente de las tropas romanas. El río Anat de la GE es llamado, en Plinio, Anatis (HN 5.9.4: ad flumen Anatim), término no recogido, por ejemplo, en el Diccionario latino-inglés de Lewis-Short. Como el texto de Plinio trata de saber la distancia en que se extiende el monte Atlas, hacia occidente, hasta llegar a dicho río (486 millas romanas, según el naturalista; una milla equivalía a mil pasos=1.481 m), algunos han pensado que sea el actual Oum er-Rbia. Otros, en cambio, creen que el homónimo río citado por Polibio corresponde al actual Drâa. Las dificultades son muy grandes, porque hemos perdido los pasajes donde Polibio hablaría de dicho viaje. 
La segunda está dedicada al comportamiento de los leones:

E viven mucho los leones, e diz que esto se prueva porque fallan los omnes muchos d'ellos sin dientes. Un sabio que llamaron Polibio dize que los leones viejos comen a los omnes porque non pueden ya por su correr alcançar las bestias, e por esto fallamos en las estorias que los leones que muchas vezes cercaron cibdades en África pora tomar ý algunos omnes que comiessen. E dize esse sabio Polibio que fue él con ell emperador Scipión en África e vío allí cerca algunas cibdades leones enforcados; e cuando preguntó Scipión a essos de África por qué era aquello dixiéronle que porque cuando los otros leones viniessen e los viessen a aquéllos assí estar que oviessen miedo de otra tal pena e fuyessen, ca diz que assí lo fazién. E el león á por natura de seer piadoso al qui se le omilla, e all omne que se echa ant'él en tierra nol fazen ningún mal. E que cuando mal quiere fazer quel faze más aína a los varones que a las mugieres, e a los moços nuncua va si non con grand arrequexamiento de fambre ${ }^{65}$.

\subsection{Crates de Malo (1)}

Floreció en la primera mitad del II a. C. Procedente de Malo (Cilicia) tuvo gran importancia en la corte de Pérgamo, hasta tal punto que Plinio (HN7.13) le llama «Crates de Pérgamo». Conservamos 86 fragmentos. Fue relevante como gramático y crítico literario, actividades en que siguió las orientaciones estoicas. La $G E$ lo cita a propósito de las serpientes venenosas: «Peró un sabio que ovo nombre Crates de Troya, que fabló de la natura de los omnes e de las serpientes, cuenta que en una isla de septentrión que dizen ellos Ponton á otrossí un linage de omnes, e llámanles los ofiogenes, e diz que éstos an natura que si tañen la ferida dell omne que la serpiente le faze que sana, e si ponen la mano en el ferido desque ell empoçonamiento viene a venino que gelo sacan del cuerpo e guarecen $»^{66}$.

\subsection{AgatárQuides de CNido (2: Agarchachides)}

Fue un historiador, geógrafo y filósofo del II a.C. Vivió aproximadamente entre los años 215-145 a. C. Escribió un tratado sobre los asuntos de Asia (10 libros),

${ }^{65} G E$ I.20.10. El texto se atiene, en general, a Plinio, $H N$ 8.48-52.

${ }^{66} G E$ I.8.15. La obra alfonsí sigue a Plinio, $H N 7.13$. Lo de «una isla de septentrión que dizen ellos Ponton», es allí, realmente, «en los alrededores de Pario»: Crates Pergamenus in Hellesponto circa Parium genus hominum fuisse, quos Ophiogenes vocat, serpentium ictus contactu levare solitos et manu inposita venena extrahere corpori. Notemos, además, que el «Crates Pergamenus» del naturalista romano se ha transformado en «Crates de Troya». Para los ophiógenes («nacidos de serpientes») tenemos dos referencias en griego: Estrabón (13.1.14) localiza efectivamente en la ciudad de Pario (en Misia, junto al Helesponto) la existencia mítica de los citados; los varones, de entre los mismos, podían curar las mordeduras de serpientes, y el fundador de la tribu se transformó en ser humano en vez de la serpiente que antes había sido. Por su lado, Eliano ( $N A$ 12.36) cuenta que en Frigia una serpiente divina se unió con Halia, hija de Síbaris, y del enlace nacieron los primeros ofiógenes. 
otro acerca de los pertinentes a Europa (49 libros), y un tercero, titulado en latín De Mari Erythraeo, distribuido en cinco libros. Plinio lo cita tres veces. Las dos menciones presentes en la parte estudiada de la $G E$ las leemos en el mismo pasaje:

Otrossí cuenta otro sabio que ovo nombre Agarchachides ${ }^{67}$ que en África á otra yente a que llaman los psillos, e ovieron este nombre d'un rey que dixieron Psillo, e yaze enterrado en cabo de las tierras de las arenas, e diz que a estos psillos nace por natura un venino en los cuerpos que si a las serpientes tañen con él que las matan, e otrossí que si ellas le uelen que con ell olor solo d'él se aduermen ${ }^{68}$, e cuenta que en el su tiempo avié uno d'aquellos omnes. $\mathrm{E} \mathrm{diz}{ }^{69}$ que en Italia otrossí avié un linage de omnes d'esta natura misma. En cabo d'estas razones cuenta otrossí esse sabio Agarchachides que en todo omne á este venino contra las serpientes, que si las omne escupe que fuyen d'él assí como si las firiesse con agua firviente, e que si la saliva del omne entra a la culuebra en la garganta que la mata, e muy más á esta fuerça la saliva dell omne si ell omne es ayuno ${ }^{70}$.

\subsection{LOS SETENTA $(59)^{71}$}

Entre el 280, comienzo de sus trabajos, y el 100 a. C., fin de la versión, los así llamados, y durante varias generaciones, tradujeron al griego (koiné) los 44 libros de la Biblia hebrea y aramea. La versión de los Setenta abarcó también libros que para algunos son apócrifos. La traducción la había propuesto Ptolomeo II, Filadelfo, y los traductores fueron 72 realmente, en un primer momento, enviados a Alejandría por el Gran sacerdote de Jerusalén.

En la $G E$, dentro de la sección estudiada, son citados como «los LXX» (33 veces; de ellas, 24, junto a Trasladadores), y «los Setaenta/Setenta Trasladadores», 21 secuencias; además, sólo como «Los trasladadores», cuatro veces. Nótese una preferencia

${ }^{67}$ Así en Indice, 2015.

${ }^{68}$ Omite la General Estoria un asunto interesante y recogido por Plinio (HN7.14): «y tenian la costumbre de exponer ante las más feroces de ellas a sus hijos recién nacidos y, de ese modo, probar la virtud de las mujeres, pues las serpientes no huían de los nacidos de sangre adúltera» (mos vero liberos genitos protinus obiciendi saevissimis earum eoque genere pudicitiam coniugum experiendi, non profugientibus adulterino sanguine natos serpentibus).

${ }^{69}$ A partir de aquí hasta el final de la cita parecería que todo fuera una afirmación del geógrafo antes citado. En cambio, corresponde al propio Plinio: en primer lugar referido a los marsos, un pueblo de Italia: y, a continuación, a todos los hombres, en general.

${ }^{70}$ GE I.8.15. Corresponde al Fr. 86F20b de Agatárquides, texto que nos ha llegado en griego gracias a Eliano, $N A$ 16.27. El contenido esencial nos lo transmite Plinio, HN7.15, quien refleja bien el antropónimo Agatharchides (en griego, transcrito, Agatharchidès).

${ }^{71}$ Por número de citas ocupan el séptimo puesto dentro de la $1^{\text {a }}$ parte de la GE. Véanse sobre los mismos Eisenberg, 1973, y Francomano, 2011, sobre el proceso seguido en la GE para romancear, prosificar y glosar la Biblia. Respecto a cómo la $G E$ creó un nuevo vocabulario, adaptando el léxico latino al sistema fonético y rítmico del castellano, véase Morreale, 1969. 
evidente por la versión más breve: «los LXX». Hay, por otro lado, un caso dudoso ${ }^{72}$. El total de apariciones del calificativo «Trasladadores» es de 49.

La $G E$ recurre a ellos, en paralelo y contraste con otras cronologías, al fijar los años que duró la primera edad (desde Adán hasta Noé), la segunda (desde Noé hasta Abrahán) ${ }^{73}$ y la tercera (desde Abrahán hasta el último año del rey Saúl y primero del rey David ${ }^{74}$. Se tienen en cuenta también los datos de la versión hebrea, y se menciona en ocasiones lo dicho por «maestre Pedro en el Libro de las generaciones del Viejo Testamento " ${ }^{75}$. El contraste entre lo afirmado en la versión hebrea y lo suministrado por los Setenta se ofrece también a propósito de la muerte de Jacob ${ }^{76}$ y de la muerte de Josép ${ }^{7}$. En ambos casos se dan, además, los años trascurridos desde el «comienço del mundo e de Adam», los años de Noé, el diluvio de Noé y el momento de la separación de las lenguas.

La $G E$, en la sección primera, habla, efectivamente, de seis edades ${ }^{78}$. De las tres primeras se establecen los límites temporales: $1^{\text {a }}$. Desde el comienzo hasta Noé; $2^{a}$. Desde Noé hasta Abraham; 3a . Desde Abraham hasta el último año del rey Saúl y primero del rey David. Además, se nos dice que de las otras tres edades se hablará en otros lugares. La $G E$, para fijar esas tres primeras, recurre al testimonio tanto de la versión hebrea como la dada por los Setenta. Otros momentos en que se computan los años por los diversos sistemas antes aludidos son: el nacimiento de Moisés ${ }^{79}$ y la muerte de Moisés ${ }^{80}$.

Recojo ahora cuatro ejemplos de la presencia, en la $G E$, de los Setenta, junto a otras fuentes cronológicas:

\subsection{1.}

Acaecieron la venida de Moisén a Egipto, e aquellas plagas de Dios sobre Faraón e sobre los egipcianos e sobre las sus cosas, e la salida de los fijos de Israel de Egipto,

${ }^{72}$ GE I.21.prólogo: «Pues que vos esto avemos dicho del prólogo e de los esponimientos de los santos padres tornaremos agora a contarvos d'aquello que diz la letra de la Biblia, e Josefo e Jerónimo e Teodocio e los otros trasladadores e otrossí los santos padres que esplanaron lo que éstos dixieron». Hay otras dos referencias donde tenemos sólo «Trasladores», en contextos donde no hay duda de quiénes se trata: $G E$ I.4.1 y I.9.47.

${ }^{73}$ Para estas dos primeras edades, véanse GE I.3.1 y I.10.2, con dos menciones de los LXX.

${ }^{74} G E$ I.10.3.

${ }^{75} G E$ I.3.1. Abarca también la paráfrasis latina realizada por Pedro Coméstor, hacia 1170, en su Historia Scholastica.

${ }^{76} G E$ I.9.39. Con cuatro referencias de los LXX.

${ }_{77} G E$ I.9.47. Vemos cuatro alusiones de los LXX.

${ }^{78} G E$ I.10.2. Habla, incluso, de una séptima edad: ( $G E$ I.14.25) «E segund fallamos por escritos de muchas estorias de sabios por este día seteno nos es dado a entender la setena edad en que será el mundo acabado, e folgarán las almas santas con Nuestro Señor Dios».

${ }^{79}$ GE I.11.29. Tres menciones de los LXX.

${ }^{80} G E$ I.29.25. Tres veces los LXX. 
e otrossí el diluvio de Tessalia, e la quema de Etiopia e las otras pestilencias que dize Plato $^{81}$ que contecieron por los otros logares de las otras tierras por el mundo andados de Adam III mil e CCCC e XLI año segund los ebreos, e III mil e DCCCC e LIX segund los LXX Trasladadores, e de Noé e del su diluvio mil e DCC e LXXV segund los ebreos, e segund los LXX mil e D e XV, e del departimiento de las lenguas mil e DC e LXXIIII, e segund los LXX mil e CCCC e XIIII, e de Abraham D e XLIII ${ }^{82}$.

\subsection{2.}

Assí como lo avemos por los escritos de Moisén e de Jerónimo e de Josefo e de maestre Pedro e por los dichos de Agustín e de Orígenes e de Beda en las glosas e de todos los otros esponedores, e assí lo otorgan Teodocion en su traslado e los LXX trasladadores en el suyo, que en todo sacrificio que en la vieja ley fue mandado fazer era siempre ofreçuda a Dios e dada toda la gordura que estava dedentro de los cuerpos de los ganados que sacrificavan e quemada sobr'ell altar a onra d'él ${ }^{83}$.

\subsection{3.}

Pues de la primera de todas estas razones fablaron Moisén e Josefo e Jerónimo e Teodocio e los LXX Trasladadores, e los esponedores d'ellos, como Augustín, Orígenes, Beda e maestre Pedro e otros muchos, e departiéronlo en el primero d'estos V libros en que contaron de la criança de las cosas, como avedes oído que dixieron Moisén e Josefo e Jerónimo e los otros en la primería d'esse libro, en el comienço crió Dios el cielo e la tierra; e en estas dos cosas entiéndense todas las otras creaturas, onde vos dixiemos que pusieron nombre Génesis a aquel libro primero porque fabla de las creaturas e de las crianças d'ellas ${ }^{84}$.

\subsection{4.}

Dicho avemos de Moisén e de Aarón e de María su hermana e de Calef su marido d'ella e de Balaam segund que lo cuentan Moisén mismo e Jerónimo en la Biblia, e Josefo en el su libro, e Teodocio en su traslado, e los otros LXX trasladadores otrossís ${ }^{85}$.

\subsection{Artemidoro de Éfeso (2: Artemidoro, Artenidor)}

Geógrafo griego del siglo I a. C., autor de un tratado en once libros, titulado, en griego transcrito, Geōgraphía, del que tenemos conocimiento por Estrabón,

${ }^{81}$ En cuatro ocasiones habla Platón de la peste (en griego transcrito, loimón): Smp.188b, 201d (alusión a la peste de Atenas), Lg.709a (leemos que muchos cambios políticos se han producido a causa de pestes), 906c (se establece un cierto paralelo entre la peste, la ambición excesiva y la injusticia en la sociedad).

${ }^{82} G E$ I.13.20. Otras tres presencias de los LXX.

${ }^{83} G E$ I.17.25.

${ }^{84} G E$ I.21.prólogo.

${ }^{85} G E$ I.28.9. 
un epítome de Marciano de Heraclea (geógrafo del IV d. C.) y diversas alusiones de otros geógrafos. Es citado varias veces por Plinio. No hay que confundirlo con Artemidoro de Éfeso, del II d. C., responsable de un tratado de interpretación de los sueños.

En la parte estudiada de la $G E$ ya lo hemos visto en el apartado 2.14 como Artenidor ${ }^{86}$. Y también como Artemidoro, en nuestro apartado 2.1.28 .

\subsection{Alejandro Polihístor (2: AleXandre Polistor $)^{88}$}

Cornelio Alejandro Polihístor, gramático e historiador griego que obtuvo de Sila la ciudadanía romana, llegó a Roma como prisionero de guerra a comienzos del s. I a. C. Fue autor prolífico de escritos de contenido diverso (de ahí el apelativo de origen griego, Polihístor, es decir, «el que relata o cuenta muchas cosas»), etnografías y curiosidades del Oriente, que quería dar a conocer en la capital. Dos veces seguidas lo leemos en un pasaje referente al casamiento de Abrahán, tras la muerte de Sara, con Cetura ${ }^{89}$, y asimismo a los hijos habidos con ella:

E de las razones que Josefo cuenta sobr'esta estoria en este logar aduze ende por testigos a Alexandre Polistor, que dize que compuso muchas estorias, e Cleodemo profeta, que ovo otra guisa nombre Malco, que escrivió la Estoria de los judíos. Onde dize este Cleodemo Malco que Abraham muchos fijos ovo en Cetura. E nombra él ende estos tres por estos nombres: Efaram, Surim, Afram. E cuenta que d'este Surim ovo nombre Assiria aquella tierra; e de Afram e de Eferam diz que poblaron la cibdad Abiram, e d'ellos ovo nombre esta cibdad e la provincia de África. E estos dos Afram e Eferam cuenta Josefo e Alexandre Polistor e Cleodemo Malco que descendieron a Libia ${ }^{90}$.

${ }^{86}$ El Índice, 2015, lo presenta así, como autor distinto de Artemidoro. Hay algunos testimonios tardíos en que se indica que Artemidoro se había ocupado de algunas localidades de Egipto. Así, lo acredita Elio Herodiano (De prosodia catholica, en Grammatici Graeci, 3.1.94.11); y, más tarde, Esteban de Bizancio (23.22).

${ }^{87}$ En el fragmento 18a de Hecateo de Abdera (realmente recogido de un escolio a las Argonáuticas de Apolonio, 4.259) leemos que Artemidoro se habría opuesto a una teoría de dicho Hecateo en la que se decía que el río Fasis iba hasta el Océano, y, desde allí, hasta el Nilo, de donde se dirigía al Mediterráneo (propiamente, a «nuestro mar»), sosteniendo que esa afirmación era una falsedad.

${ }^{88}$ Lo cita Josefo sólo una vez: $A I$ 1.240. De los autores de obra conservada son Josefo, Plutarco y Elio Herodiano los primeros en mencionarlo. La Suda, en el siglo X, dice que Polihístor escribió obras innúmeras. Entre éstas figura una Historia de los judios en la que resumió y recogió otras muchas del mismo asunto. Entre los alumnos del mencionado brilló Higino, el autor de las Fábulas, tan importantes para el estudio de la mitología.

${ }^{89} \mathrm{La}$ Agar de la Biblia.

${ }^{90}$ GE I.6.16. Cleodemo Malco (en latín Cleodemus Malchus) fue un autor judío que brilló en torno al 200 a. C. y escribió en hebreo. Sólo nos han llegado unas pocas líneas de sus obras. Realmente lo que nos dice Josefo $(A I 1.240)$ es que Cleodemo era profeta, y también que se llamaba Malco. 


\subsection{Nicolás de Damasco (2: Nicolao)}

Fue un historiador sirio que vivió en los años del emperador Augusto. Compuso una historia universal en 144 libros, de la que solo nos han llegado unos pocos fragmentos. También dejó una autobiografía, una vida de Augusto y algunos textos filosóficos. Josefo lo cita con cierta frecuencia.

A propósito de la Pentápolis bíblica, Sodoma y Gomorra entre ellas, la $G E$ nos dice: "Josefo cuenta en el seteno capítulo que moró Abraham en tierra de Canaán en la cibdad de Damasco, e aun diz que fasta este día de oy á en Damasco un barrio quel dizen la morada de Abraham, e aun que los que ý moran que se precian por ello e se tienen por más nobles. Onde dize en el cuarto libro de sus estorias Nicolao de Damasco, que fue un sabio de aquella tierra que escrivió las estorias d'ella, Abraham viniendo avenedizo con su hueste de la tierra de los caldeos que yaze sobre Babiloña, regnó en Damasco ${ }^{91} »^{92}$.

Ya lo hemos visto anteriormente, nombrado simplemente como Nicolao ${ }^{93}$. Cf. el apartado 2.2.1.

\subsection{ISIDORO DE CÁrACE (2: ESIDORO)}

Isidoro de Cárace (Isídōros ho Charakēnós, en latín, Isidorus Characenus) fue un geógrafo de la época del emperador Augusto, autor de las Estaciones partas, obra redactada en griego y no conservada, donde recogía un itinerario del camino que unía Antioquía con la India, pasando por las sucesivas estaciones, o paradas, donde se detenían las caravanas que marchaban por esa ruta. Plinio lo cita bastante, pues Augusto seleccionó al indicado para que recogiera toda la información posible sobre el oriente, especialmente en lo concerniente a Armenia y el territorio de los partos y árabes, pues hacia esos lugares iba a hacer una campaña militar Gayo César, un nieto del emperador (realmente, hijo adoptivo del mismo), el cual moriría durante la misma.

La $G E$ lo cita como Esidoro" ${ }^{94}$ cf. apartados 2.1.2; 2.14.

\subsection{JERÓNIMO EL EGIPCIO (3)}

Llamado en latín Hieronymus Aegyptius, Josefo lo menciona dos veces (AI 1.94; 107), considerándolo autor de la historia antigua de Fenicia. El prosista judío es el primer escritor de obra conservada que lo nombra. Dicho Jerónimo es recogido

\footnotetext{
${ }^{91}$ Para esta noticia, cf. Josefo, $A I 1.159$.

${ }^{92} G E$ I.5.2. Véase Josefo, $A I 1.159$.

${ }_{93}$ El Índice, 2015, lo da como un autor distinto del ya referido.

${ }^{94}$ Así en el Índice, 2015.
} 
después en las obras de Eusebio y Jorge Cedreno. Los estudiosos lo sitúan al final del periodo helenístico o a comienzos del romano.

La $1^{\text {a }}$ parte de la $G E$ lo cita tres veces, tanto por haber escrito sobre las antigüedades (sc. la historia antigua) de Fenicia, así como por haberse ocupado del diluvio de Noé y de la famosa arca. Ya lo hemos encontrado en una ocasión: cf. el apartado 2.2.1. Veamos las otras dos referencias: «Otrossí Jerónimo de Egipto, que escrivió la estoria de la Antigüedat de Feniça, la cibdat de Egipto que pobló Feniz, hermano de la reína Europa e del rey Cadmo, e fijo del rey Agenor, fabló otrossí del fecho d'este diluvio e d'esta arca, e otrosí Maniseas de Damasco en el LXXXX ${ }^{\mathrm{V}} \mathrm{I}^{\circ}$ libro de sus estorias dixo d'esta arca assí: un mont muy alto á en tierra de Armenia sobre tierra de Numiada, e el mont á nombre Baris»». Y, en otro lugar: «E d'esta guisa fablaron d'este diluvio e del arca Beroso de Caldea e Jerónimo de Egipto, e Manaseas de Damasco»"

\subsection{JUBA $(5)^{97}$}

Dicho personaje ( 52 a. C.-23 d. C.) es nombrado por Plinio más de 60 veces en su Historia Naturaps. Para mencionarlo con propiedad, deberíamos llamarlo Juba II: rey de Mauritania entre los años 25 a.C. y el 23 d.C. Precisamente, su padre, Juba I, fue derrotado en Tapso (46 a.C.) por Julio César y se suicidó poco después. César recogió al niño, luego Juba II, el cual se crió y educó en Roma. Escribió numerosas obras en griego o latín sobre historia, historia natural, geografía, gramática, pintura y teatro, pero sólo nos han llegado algunos fragmentos. Monarca estudioso, organizó, a comienzos de la era cristiana, la primera expedición a las Islas Canarias. Asimismo se ocupó de diversos aspectos botánicos del monte Atlas.

En la primera parte de la $G E$ tenemos cinco menciones de dicho rey de Mauritania ${ }^{99}$. La obra alfonsí recoge un largo párrafo en que leemos cómo Plinio había afirmado que dicho monarca se había interesado por el monte Atlas, localizado en Mauritania (África): se extiende en la explicación sobre el cocodrilo (llamado allí

${ }^{95} G E$ I.2.6. Más noticias en el texto recogido en el apartado 2.16 .

${ }^{96} G E$ i.2.6.

${ }^{97}$ Sus fragmentos han sido traducidos por García García, 2007. Eisenberg, 1973 cita el nombre del escritor a propósito de una lectura corrupta del texto de Plinio.

${ }^{98}$ Hay serias dudas sobre si Plinio utilizaba directamente los textos de Juba o si habla de ellos a través del relato de Seboso (Statius Sebosus), geógrafo, quizá del siglo I a. C., del que se duda que conociera bien la obra de Juba, pues su propósito posiblemente era impresionar a sus lectores con relatos sorprendentes. El citado Seboso escribió un periplo; Plinio lo cita en cuatro ocasiones, y es cuanto sabemos de él.

${ }^{99}$ Esa Mauritania ocupaba parte de Marruecos y la Argelia actuales. Fue anexionada por Roma y dividida en las provincias de Mauritania Tingitana y Mauritania Cesariense. 
cocadriz, término que el $D L E$ eliminó hace años por obsoleto) que vive en dicho país; explica que del Atlas nace una fuente que origina un gran lago, y que, para algunos, de acuerdo con lo que llueve o nieva donde dicha fuente se halla, así crece o mengua el Nilo; se menciona también la fuente Nigris de Etiopía ${ }^{100}$. Además, a partir de otra cita, vemos que se habla de dos Mauritanias ${ }^{101}$, y de que Juba fue el primero que reinó sobre ambas. Resultó ser un buen rey que estudió la planta llamada euforbio, la cual, se nos dice, tiene un jugo blanco como la leche, y es buena para mantener la claridad de la vista y para curar las mordeduras de serpientes y, asimismo, sacar la ponzoña que éstas hubieran inoculado en las personas mordidas ${ }^{102}$; se nos dice que dicha planta fue usada por primera vez "por un físico que dixieron Eufarbio" (Sabemos, por otras fuentes, que el euforbio fue descubierto durante el reinado de Juba: cf. Dioscorides, 3.82.2).

\subsection{Hestieo (1: Esto)}

Historiador del I d. C. En el texto estudiado de la $G E$, sólo lo leemos una vez, pero con la grafía deformada: Esto ${ }^{103}$. Pensemos que del Hestiaîos del griego, tenemos Hestiaeus, en latín. Ahora bien, hay muchas dudas sobre quién fue ese Hestieo, al que menciona Josefo ( $A I$ 1.107. Véase apartado 2.2.1) como autor de una historia de Caldea. Los estudiosos lo sitúan al final del periodo helenístico o al comienzo del romano. También lo encontramos en AI 1.119 (sólo esas dos referencias da el historiador judío). Posteriormente, Eusebio, Jorge Cedreno y Jorge Sincelo recogieron simplemente la primera cita de Josefo ya apuntada.

\subsection{Moco (1: MAÇO)}

Môchos sería la transcripción del griego; Mochus es la grafía en latín. En la $G E$, dentro de la parte estudiada, lo encontramos sólo una vez, donde se le llama $\mathrm{Maço}^{104}$ (Cf. el ejemplo en 2.2.1). El primer autor griego de obra conservada en citar ese antropónimo es Estrabón (16.2.24), pero surge un problema cronológico, pues el geógrafo afirma que, si damos crédito a Posidonio, la teoría de los átomos procede de Moco de Sidón, que habría vivido antes de los tiempos de Troya. Esa explicación la acepta también Sexto Empírico (M. 9.363) que cita a Moco de Fenicia como un precedente de Leucipo y Demócrito, los impulsores de la teoría de los átomos.

\footnotetext{
${ }^{100} G E$ I.5.7. Sobre este contenido, véase Plinio HN 5.51-54. Cf. nuestro apartado 2.1.2.

${ }^{101} G E$ I.10.29. En la secuencia leemos cuatro menciones de Juba.

${ }^{102}$ Véase Plinio, HN 25.77-79.

${ }^{103}$ Así en Índice, 2015.

${ }^{104}$ Con esa grafía lo vemos en Índice, 2015.
} 
Véase también Ateneo (3.126a). Ahora bien, ese Moco parece diferente del que nos interesa. Efectivamente, según Josefo (AI 1.107), que lo cita sólo una vez, figura entre quienes escribieron una historia o relato sobre Caldea, sin dar ninguna indicación sobre la cronología.

\subsection{JOSEFO $(743)^{105}$}

2.29.1. Flavio Josefo (37-100 d. C.), nacido en Jerusalén, hijo de un matrimonio formado por un sacerdote y su esposa de sangre real, dio en seguida muestras de su aplicación e inteligencia. Visitó Roma en el año 64 y quedó impresionado por el poder romano. Además de esas noticias, el propio autor nos ofrece otros numerosos datos en su Vida, obra tardía, terminada al final de sus días. Intervino, como intérprete y mediador, al lado de Tito, hijo del emperador Vespasiano y posterior heredero del poder supremo, en la guerra declarada por Roma contra los judíos (conflicto relatado en su Historia de la guerra judaica contra los romanos, en siete libros, publicada en los años 75-79; en latín, Bellum Iudaicum=BI). El historiador viajó a Roma con los vencedores y ya vivió siempre allí gozando de los más altos honores otorgados por los sucesivos emperadores y teniendo a mano para su trabajo las inmensas bibliotecas imperiales. Para la $G E$, en la parte que nosotros estudiamos, la obra esencial de Josefo es Antigüedades judías (=Antiquitates Iudaicae $=A I$ ), aparecida en los años 93-94, en veinte libros. Abarca sucesos desde la creación del mundo hasta el año 66 y tiene como objetivo engrandecer al pueblo hebreo a los ojos del mundo grecorromano. Con respecto al texto bíblico, Josefo manejó tanto el hebreo-arameo como la versión griega de los Setenta, incorporando no pocos elementos de tradición oral (así, el nacimiento e infancia de Moisés; la campaña de éste contra los etíopes, etc.). Como hemos visto en este trabajo, el escritor menciona en ocasiones sus fuentes históricas: Beroso, Manetón, Nicolás de Damasco, etc. La cuarta obra del historiador es Contra Apión (en latín, Contra Apionem=Ap.), aparecida después del 94, donde tenemos una verdadera apología del judaísmo y, además, una exposición general del antisemitismo tal como se generó en el siglo I. Aparte de su importancia esencial para la historia de los judíos, Josefo ha sido utilizado por numerosos estudiosos de la Biblia, tanto por las similitudes entre ambos conjuntos literarios como

${ }^{105}$ De entre todos los autores griegos o latinos es el más mencionado en la $1^{\text {a }}$ parte de la $G E$. Para la presencia y utilización de Josefo en la GE, Lida de Malkiel, 1959; Malkiel, 1968-1969; Rico, 1972; Eisenberg, 1973; Feldman, 1984 (revisa el texto, las traducciones, la denominación Josippus, su vida, la paráfrasis de la Biblia, el historiador, sus fuentes, las religiones, arqueología, vocabulario y estilo, influencias hasta el siglo XX - con un apartado dedicado a la literatura española, 865-868-, y en la literatura contemporánea, más desiderata e índices); Perona, 1989; Fraker, 1996: 177-190, ha señalado problemas de mala traducción del texto de Josefo en la obra alfonsí; Martin, 2000; Avenoza, 2003; Nieto Ibáñez, 2004; Almeida-Trujillo, 2008; Puerto Benito, 2008; López Férez, 2014, 2020a; Bautista, 2017; etc. 
por las discrepancias de los mismos. Muy leído desde la publicación de sus obras, la imprenta ayudó a la divulgación de las mismas en toda Europa, especialmente mediante las traducciones latinas, entre las que sobresale la de 1481. Por su lado, la edición princeps del texto griego no vería la luz hasta $1544^{106}$.

Por mi parte, he contado 743 apariciones del antropónimo "Josefo» en la parte estudiada de la GE. Me ocuparé de algunos puntos esenciales en el apartado 2.29.4.

2.29.2. Josefo fue traducido al latín relativamente pronto ${ }^{107}$. Posiblemente corresponde al círculo de Jerónimo la traducción de la $B I$ atribuida a Pseudo Rufino de Aquilea ${ }^{108}$ (Tyrannius Rufinus Aquileiensis, cuya vida se fija en los años 345-411), bastante literal, realizada en el siglo IV, y que, hasta la fecha, no cuenta con una edición crítica. Posteriormente, Casiodoro encargó las versiones de $A I$ y del $A p$., realizadas por sus colaboradores en el monasterio de Vivarium ${ }^{109}$.

2.29.3. A la presencia e importancia de Josefo en la $G E$ dedicó un excelente estudio Lida de Malkiel ${ }^{110}$. Por su utilidad para nuestro objetivo, resumo los puntos esenciales de dicha aportación.

2.29.3.1. La investigadora se detiene, en primer lugar, en la influencia de Josefo dentro de la literatura castellana desde el siglo XII; examina la $G E$ como Biblia historial, pues la obra fue recogiendo noticias referentes a otros pueblos, siguiendo el método de Eusebio y Jerónimo, y, por eso, gusta tanto de la Historia scholastica de Pedro Coméstor. De esa orientación de la $G E$, viene también la importancia dada en ella a Josefo, quien en sus $A I$ había unido la historia judía con la de otros pueblos. El historiador, en dicha obra, libros 1-13, aborda el contenido histórico de la Biblia; y en los libros últimos, 14-20, expone una datación según los calendarios judío, griego y macedónico, lo que le convierte en un modelo para Eusebio y Jerónimo. En este sentido conviene subrayar que incluso Jerónimo (de viris illustribus 13), adverso a la Biblia como literatura, elogia a Josefo, afirmando que se le apreciaba en alto grado y que su fama había llegado hasta sus propios días.

2.29.3.2. La $G E$ acude, en algún pasaje a Josefo porque éste "cuenta más», y se detiene en aspectos no tratados en la Biblia ni en otros comentaristas de la misma.

\footnotetext{
${ }^{106}$ Son útiles las bibliografías ofrecidas en http://www.josephus.org/books.htm y https://www. oxfordbibliographies.com/view/document/obo-9780199840731/obo-9780199840731-0049.xml.

${ }^{107}$ Es muy conveniente consultar el The Latin Josephus Project, indicado en la Bibliografía. Para las traducciones latinas de Josefo, consúltense Levenson - Martin, 2016a y 2016b.

${ }^{108}$ Véase Thuval, 2019.

${ }^{109}$ Se conocen 171 manuscritos de dicha traducción. El texto de los primeros cinco libros fue publicado en edición crítica por F. Blatt.

${ }^{110}$ Lida de Malkiel, 1959. Léase también su aportación de 1972.
} 
Otro asunto muy relevante es que Josefo juzgaba auténtica la tradición oral, incorporándola en su historia (Lida, 1959,168).

2.29.3.3. Lida examina algún ejemplo de amplificación de la $G E$ a la vista del relato bíblico y la explicación de Josefo: concretamente el asunto de cómo Esaú se casó con las dos mujeres cananeas. La estudiosa señala el interés de Josefo por el plano didáctico, la enseñanza moral, y que, en ese punto, a la $G E$ le sucede lo mismo.

2.29.3.4. Unas veces la $G E$ se empeña en poner de acuerdo a Josefo con la Biblia y con la Historia scholastica; otras veces, se aparta de la interpretación de Josefo, pues éste no recoge ciertos milagros que la $G E$ sí ofrece; en ocasiones acepta las interpretaciones racionalistas de Josefo, pero otras, no; asimismo, la obra alfonsí incorpora, en determinados lugares, pasajes o asuntos omitidos por Josefo, pues iban contra el monoteísmo judío. Así, la historia del becerro, los querubines, el altar y bosque de Baal, el efod ${ }^{111}$ de Gedeón. De otro lado, si, en ciertos lugares, Josefo atenúa los datos de la Biblia, la $G E$, unas veces lo sigue, pero otras, no.

2.29.3.5. La $G E$ sabe que, al seguir a Josefo, tenía a su lado toda la tradición historiográfica occidental, pero, no obstante, elige o amplía el relato mediante las obras arábigas y las de otros numerosos comentaristas.

2.29.3.6. La $G E$ sigue la versión latina de las $A I$, la realizada quizá en el círculo de Jerónimo, pero atribuida al Pseudo-Rufino de Aquilea ${ }^{112}$.

2.29.3.7. Respecto a la comprobación de las fuentes, leemos en el texto alfonsí: "catamos nós el Josepho e fallamos que es assí» ${ }^{113}$, pero, realmente, los redactores no «cataron», ni se percataron del trueque que había hecho Rabano ${ }^{114}$, atento

${ }^{111}$ Con las joyas tomadas a los vencidos, Gedeón se hizo elaborar un efod. No hay tampoco acuerdo entre los expertos en relación con dicho objeto: unos dicen que se trataba de todo un atuendo sacerdotal con sus joyas y adornos; otros, que se hace referencia a una tabla o instrumentos para hacer consultas a Yahveh. Sin embargo, el citado elemento llevó nuevamente a la idolatría a los israelitas. Según el $D L E$, el efod es una vestidura de lino fino, corta y sin mangas, más o menos lujosa, que se ponen los sacerdotes del judaísmo sobre todas las otras y les cubre especialmente las espaldas.

${ }^{112}$ Lida, 1959: 172, cree que se trata de la realizada por orden de Casiodoro en el siglo VI. La estudiosa revisa una serie de lugares donde la indicada versión latina ha dado lugar a confusiones tanto en la Historia scholastica como en la GE. Parte Lida de su propia versión de la traducción inglesa de Josefo realizada por Thackeray et alii (Loeb), y de la edición del Pseudo-Rufino elaborada por Girolamo Squarzafico, Venecia, 1486 (Véase Bibliografía).

${ }^{113}$ GE I.1.1.

${ }^{114}$ Puede acudirse a Rabano Mauro: Rabanus Maurus, Commentariorum In Genesim Libri Quatuor, en la Patrologia latina, vol. 107, col. 508. Con referencia a Jubal, leemos: De hoc Josephus historiographus Judaeorum ita refert: Jubal autem, inquit, musicam coluit et psalterim citharamque laudavit. 
a la lectura de la Biblia, cuando, al tratar el origen de la sabiduría, puso Jubal en vez de Set, a quien se la había atribuido Josefo.

2.29.3.8. La $G E$ tiene a Josefo casi por un santo, pues cabe deducirlo de frases alfonsíes como «Josefo e los otros sanctos padres» ${ }^{115}$.

2.29.4. Por mi lado destacaré algunos puntos que me han parecido dignos de señalar en la parte estudiada de la $G E$.

2.29.4.1. Algunos asuntos los trata Josefo, pero no la Biblia, y llaman la atención en la GE. Así el interés de los hijos de Set por la astrología ${ }^{116}$ (Cf. $A I$ 1.68-9).

2.29.4.2. A su vez, la $G E$ se interesa, en ocasiones, por aspectos que no trata Josefo. Tal ocurre con la referencia a los 37 hijos que Lamec tuvo con sus dos mujeres ${ }^{117}$.

2.29.4.3. Hay también asuntos que la $G E$ adjudica a Josefo, pero que éste no dice o lo afirma de otra manera: «De los otros seis fijos de Jafet fallamos lo que avemos dicho, mas de Tubal nin Moisén nin Josefo non veemos que fablassen señaladamientre de puebla que él fiziesse nin los suyos, si non que Moisén llama su nombre Tubal, e que Josefo le dize Jobel, e más que él pobló los jebelos, e que los jebelos son los iberos, e iberos dizen en latín por españoles» ${ }^{118}$. En realidad, Josefo ${ }^{119}$ escribe que "Teobelo funda a los teobelos, que ahora se llaman iberos» (katoikizei dè kaì Theobélous Theóbēlos, hoitines en toîs nûn Íbēres ${ }^{120}$ kaloûntai). Pero, por si fuera poco, la GE añade, además, que ese nombre «iberos» era del latín, equivalente a «españoles», afirmación donde se contienen varios errores acumulativos.

Otro ejemplo: «E fue por ventura, segund dize Josefo, porque las non sopieron nin coñocieron los griegos nin les mudaron los nombres en la sazón que los mudavan a las otras gentes e tierras. Peró dize Josefo que por apostura e fermosura de los escritos e a deleit de los que los leyén mudaron los griegos los nombres a las tierras e a las yentes ${ }^{121}$. Lo que dice realmente Josefo $(A I 1.121)$ es que los griegos cambiaron los nombres, porque, cuando tomaron después el poder, lograron la fama del pasado, embelleciendo a los pueblos con nombres de acuerdo con lo que era entendido por ellos e imponiéndoles una forma de gobierno como si fueran descendientes de ellos.

${ }^{115} G E$ I.11.50; I.17.2.

${ }^{116} G E$ I.1.27. Es relevante el interés de la $G E$ por el conocimiento de la astrología y los «estrelleros». Sobre El libro del saber de astronomía alfonsí, véase Fernández Ordóñez, 1999.

${ }^{117} G E$ I.1.14.

${ }^{118} G E$ I.3.1. Véase además otra secuencia (I.3.2): «Jobel pobló los jobelos. E éstos, segund diz Josefo, son los que agora an nombre iberos, que somos los españoles».

${ }^{119}$ AI 1.124-125.

${ }^{120}$ Pero, en realidad, esos iberos no son los de Iberia (llamada, luego, en latín, Hispania), sino un pueblo del Cáucaso.

${ }^{121} G E$ I.3.1. 
2.29.4.4. Una constante de la $G E$ es informar de cómo fue la transmisión de los saberes desde la Antigüedad, su paso por Grecia y Roma y luego entre «los latinos». Así, sin reparos cronológicos, se nos dice que Josefo afirma que los conocimientos del cuadrivio empezaron en Caldea: «E maguer que nós avemos dicho ya segund Josefo que los saberes del cuadruvio tomaron el comienço en Caldea e d'allí vinieron a Egipto e a Grecia, esto dezimos que es verdad cuanto al su comienço, mas d'otra guisa en Grecia fueron apurados e acabados e puestos en certedumbre» ${ }^{122}$. El texto alfonsí había dicho antes que el padre de Abrahán era entendido en esos saberes, pero que Abrahán lo fue de modo especial:

Cuenta Josefo en el ochavo capítulo del primero libro de la estoria de la Antigüedat de los judíos palabras ya cuanto oscuras d’esta razón de Abraham, e peró muy buenas, e son éstas en que diz assí. Abraham fue por sí omne muy entendudo en todas cosas e sabio en todas aquellas que oyera e aprendiera de los otros sabios, e en todas aquellas de que omne algo podrié asmar, e sabio otrossí e apercebudo de las cosas que avién de venir. E entendiélo por las ciencias del cuadrivio, dond era él muy grand senor, e por ende diz que fue mayor de todos los otros de la su sazón por virtud de la sapiencia que aviér ${ }^{123}$.

Como he adelantado, la $G E$ también lo afirma de Taré, el padre de Abrahán:

E él trabajava de los saberes del cuadrivio, e sobre todo del saber de las estrellas. E esto assí fallamos que lo fizieron, peró que unos más e otros menos por la mayor parte todos los padres de la liña tan bien en esta segunda edad como en la primera, assí como vos contamos en las razones de la primera edad que lo cuenta d'ellos Josefo. Entre todas las otras tierras los de Caldea se trabajavan del saber de las estrellas más que otra yente a aquella sazón. E a Tare plogó d'ello mucho, e fincó allí de morada con su compaña ${ }^{124}$.

Finalmente, la $G E$, refiriéndose al tiempo en que Abrahán vivía en Ur (Caldea), añade: «E fasta esta sazón morara Abraham en tierra de Caldea e de Mesopotamia, e estudiara ý en los saberes del arte del arismética, que es saber de cuenta, e de la geometría, que muestra el saber del mesurar e de medir las cosas del cielo. E era Abraham muy sabio d'estos e d'otros saberes más que cuantos otros maestros avié entre todos los caldeos» ${ }^{125}$. Además, añade que el citado habló de la existencia de un solo dios: «E Josefo en razón de pruevas d'esto que dixo Abraham diz en el seteno capítulo del primero libro de la Antigüedat de los judíos, e trae por testigos los sabios caldeos que

\footnotetext{
${ }^{122} G E$ I.6.28.

${ }^{123} G E$ I.4.8.

${ }^{124} G E$ I.4.2.

${ }^{125} G E$ I.4.32.
} 
fablaron del saber de Abraham $»^{126}$. Pues bien, si consultamos a Josefo veremos que éste no dice nada de los saberes de Taré, y, a propósito de Abrahán, indica que, precisamente, viviendo en Caldea, y por haber hablado en tales términos de dios ${ }^{127}$, se vio obligado a salir hacia Cananea, porque se habían levantado contra él los caldeos y los demás mesopotámicos ${ }^{128}$.

2.29.4.5. Nos detendremos en varios asuntos de los que la $G E$ refiere que constan en Josefo, cuando o no figuran en éste, o aparecen pero de forma bastante distinta. Así, con referencia a la estancia de Abrahán en Egipto, leemos en la GE:

E començó Abraham a enseñar allí a las yentes e tener escuelas de los saberes que dixiemos del arte de la astrología, e de la arismética e de la geometría, así como fazié en Caldea e en Cananea. E diz Josefo que se trabajava Abraham d'esto por estas cuatro razones: la una porque oviessen de qué bevir él e sus compañas e passar bien mal tiempo; la otra por oír los clérigos sabios d'allí e aprender d'ellos qué dizién de Dios; la tercera que si fallasse algunos que creyessen en Dios mejor e más sanamientre que de como él creyé, que toviesse él aquella carrera; la cuarta que si non fallasse en Egipto qui croviesse de Dios tan bien como él que les mostrasse él la verdad e gela fiziesse entender e creer. E maguer que Abraham fincó poco en aquella tierra tanto enseñava bien e agudamientre que de estonces aprendieron los d'allí las artes liberales e las sopieron por Abraham, qui las decogió en Caldea ó fueron primero e las enseñó él en Egipto; e por esso dizen Josefo e maestre Godofré que estos saberes primero fueron en Caldea que en otro logar, e d'allí los ovieron los de Egipto, e de Egipto vinieron a los griegos, e de los griegos a los de Roma, e de Roma a África o a Francia. E por esta razón dixo otrossí Josefo que el comienço del saber e de los reyes e de las batallas que de oriente se levantó primero, e en occidente se deve acabar. E que esto es segund que anda el sol. E por estos saberes que avemos dichos que enseñava Abraham acogiénse a él las yentes e pagávanse d'él, e dávanle por ello todas las cosas que avién mester él e sus compañas ${ }^{129}$.

Frente a esa digresión amplificada, si acudimos a Josefo ( $A I$ 1.167-168), nos informamos simplemente de que Abrahán, cuando estaba con Sara en Egipto, les enseñó a los egipcios aritmética y astronomía, saberes que ellos ignoraban hasta entonces, y que habían pasado de Caldea a Egipto y de aquí a los griegos.

Otro ejemplo lo encontramos cuando se habla de cómo Labán y Jacob hicieron las paces: «Essora luego empós estas palabras tomó Jacob una piedra e alçola allí en señal d'este fecho en aquel mont ó dixiemos que fincaran sus tiendas éll e Labam,

${ }^{126} G E$ I.4.14.

${ }^{127}$ AI 1.154-155.

${ }^{128}$ AI 1.157.

${ }^{129}$ GE I.5.4. 
e mandó a los sós aduzir otras, e ellos ayuntaron tantas que d'ella fizieron montón. E segund cuenta Josefo, era pilar alto a semejança de altar, e llamól Labam ell otero del testigo, e Jacob el montón del testimonio, cadaúno segund su lenguaje» ${ }^{130}$. Nada hay en el pasaje de Josefo ( $A I$ 1.324) que apoye los dos nombres dados al montón de piedras (en griego se trata de una columna o pilar (stếlē) que tendría la forma de altar), y menos que suegro y yerno hablaran lenguas distintas, o, al menos, que le hubieran puesto dos nombres diferentes a dicho altar.

Otrosí lo hallamos cuando, tras despedirse de Labán, Jacob volvía con su familia hacia Canaán: "Jacob, de quien avemos dicho cuando se partió de su suegro Labam, ívase pora Cananea assí como avié començado, e apareciéronle en la carrera muchos ángeles de Dios, e prometiéronle mucho bien, segund cuenta Josefo» ${ }^{131}$. En el historiador judío leemos ${ }^{132}$ que, Jacob, mientras hacía ese viaje, tuvo visiones (phantásmata) que daban buenas esperanzas, pero nada encontramos respecto a la presencia de «ángeles de Dios»" ${ }^{133}$.

Veamos dos secuencias más. Según la $G E$, parece desprenderse de Josefo que, cuando los hermanos de José fueron a Egipto a buscar trigo, éste hablaba con ellos mediante traductor: «Josep cuando les estas razones oyó quiso saber aún más por las palabras d'ellos mismos qué voluntad trayén, e maguer que les él non respondié por el su lenguage peró muy bien les entendié, ca en aquel lenguage se criara él en casa de su padre con ellos e non lo olvidara, ca era omne de buena memoria, e mandó al trujamán responder d'esta manera a las razones que ellos dixieron, segund cuenta Josefo»" 134 . La GE insiste en ese punto: "Aquella ora començaron ellos todos a dezir d'ello entre sí cuedando que lo non entendié Josep porque fablava con ellos por trujamán, e falláronse todos por muy culpados a las palabras de Rubén su hermano, e colgaron todos a tierra las cabeças, assí como sabidores del fecho cómo fuera, e tómaronse cadaúnos a emer e solloçar, e lloravan muy grievemientre e dizién[...]» $\aleph^{135}$. Ahora bien, en Josefo, José y sus hermanos conversan, sin problema alguno, desde el primer momento, y sólo, tras el primer encuentro, cuando José decidiera que se quedara en palacio uno de los hermanos como rehén hasta que trajeran a Benjamín, los otros hablaron entre sí "pensado que José no comprendería su propia conversación» (o "habla», entendida como modo de hablar, o incluso «lengua»: en griego, transcrito, ouch hēgoúmenoi tòn Iốsēon glôssēs tês autôn siniénai $)^{136}$.

Y, por último, respecto al nombre de Moisés: «E por aquel avenimiento que acaeciera assí a doña Termut quel fallara en el agua llamól Moisés, porque mois en

${ }^{130} G E$ I.7.20.
${ }^{131} G E$ I.7.21.
${ }^{132} A I$ 1.325.
${ }_{133}$ No faltan ocasiones en que el historiador habla de «ángel(es) de Dios», o «divino». Cf. AI 1.73, 189, 198, 219, 332, 333, etc.

${ }^{134} G E$ I.8.18.

${ }^{135} G E$ I.8.19.

${ }^{136} A I 2.108$. 
el lenguage de Egipto, segund cuenta Josefo, tanto quiere dezir en el nuestro de Castiella como agua, e la es como librado. E ayuntó estas dos palabras de su lenguage mois e e e fizo d'ellas este nombre Moisés, que muestra segund esto tanto como librado de muert por agua, e aun librado dell agua o de la muert del agua ó pudiera morir e perderse si aquel acorro non fuesse» ${ }^{137}$. Josefo ${ }^{138}$ nos dice escuetamente que (sc. la princesa) le puso el nombre en relación con lo sucedido al caer en el río, pues «los egipcios llaman al agua môu, y esês, a los salvados» (Recordemos que el nominativo de Moisés en griego es Mōusês).

2.29.4.6. Recojo ahora tres ejemplos de la llamada, en retórica, amplificatio, que, para muchos, comprende tanto la ampliación de lo tratado como la importancia que a dicho asunto se le otorga en el contexto. En primer lugar el relato sobre las causas de la larga vida de los antiguos:

Cuenta Josefo sobr'esto en el quinto capítulo que cuando catáremos la vida de los omnes de agora e la vida de los antigos que non tengamos que yerro ninguno á ý en aver vevido tantos años los omnes del primero tiempo. Ca diz que los del primero tiempo muchas razones avién por que visquiessen tanto. Lo uno porque eran religiosos e fazién santa vida como fraires, e eran otrossí mas decerca de la fechura de Dios, e oyeran más palabras de las que Dios dixiera a sos padres e a sos parientes, e las aprendieran ellos e las tenién. Demás que non comién en aquel tiempo si non frutas e yervas, e pocas cosas otras. Mas que aun fasta'l diluvio nin comieran nunca carne nin bevieran vino, nin d'esto nin de ál cosa ninguna a demás por que de lieve enfermassen nunca, que por ello viniessen a muerte nin minguassen nada de su vida. Demás que razona Josefo que aquellos primeros omnes que eran más cerca Dios que se trabajavan de los fechos e de los saberes en que eran las virtudes de las cosas e los nobles e grandes pros, e que era esto el saber de la astrología e de la geometría e de todos los saberes liberales e de los otros. E que en escodriñar las virtudes d'esto que era tan alta cosa e tan noble e tan provechosa que por aduzirlos a las virtudes puras e ciertas que se non podrié fazer en menos de seiscientos años, e que tanto dura ell año grand. E que por estos bienes de que se trabajavan que les dio Nuestro Señor Dios tan luengas vidas en que lo pudiessen complir. E non solamente Moisén en la Biblia e los ebreos en su ebraigo, mas aun otros sabios muchos de otras tierras e d'otras lenguas, e aun d'otras creencias fallamos que fablan en esta razón, e testiguan que fue assí. Esto tan bien en bárbaros como en griegos ${ }^{139}$.

Ahora bien, en Josefo ( $A I$ 1.106-107) leemos que aquellos hombres eran amados por Dios y hechos por Dios mismo, y su alimento era apropiado para hacerles

${ }^{137} G E$ I.11.21-23.

${ }_{138} A I 2.228$.

${ }^{139} G E$ I.2.13. Nótese la acumulación de autores. Además tres citas de Josefo. Advertimos importantes reflexiones sobre la comida y el vino. Repárese, además, en la indicación sobre la existencia en época tan remota no sólo de la astrología sino también de las artes liberales. 
la vida más larga; eran hombres virtuosos, hacían buen uso de sus conocimientos geométricos y astronómicos y por eso pudieron predecir el curso de las estrellas, al haber vivido seiscientos años, que es lo que dura el año grande. Añade el prosista que se había basado en los autores griegos y bárbaros que habían escrito sobre eso. Con todo, nada dice en punto a que hubieran vivido como frailes, ni que comieran sólo yerbas y frutas, sin tomar carne y sin probar el vino.

En segundo lugar, la $G E$ nos explica cómo, tras morir José, empezaron las malas relaciones entre egipcios y hebreos:

E dize Josefo en este logar que los de Egipto eran todos dados a maldad en aquella sazón, los unos a cobdicia, los otros a fornicio, los otros a otros vicios malos de muchas maneras; e los ebreos, que eran de buena vida, e sabidores e engeñosos pora aver algo, e todavía por su lazeria. Onde los egipcianos, que se davan a vicios e a deleit de sus cuerpos, porque sintién a los ebreos mesurados en sus comeres e lo non eran essos egipcianos, e los fornagueros otrossí, porque los sabién de buena vida e guardada d'aquel mal vicio, e querién éstos d'ellos las mugieres, e los que eran cobdiciosos porque los veyén cuerdos e muy ricos e abondados con cobdicia otrossí de levar d'ellos lo que avién, e cadaúnos lo que cobdiciavan segund sus naturas e maldades queriénlos mal todos, e cadaúnos por la su razón, como lo avemos departido, e acogiéronse luego muy de grado al mal que les el rey dizié d'ellos, e otorgárongelo todos. E como son los reyes en los sesos más agudos que los otros omnes asmó aquel rey cuáles serién las cosas por ó los él más podrié apremiar porque menguassen. E segund le enseñaron sus consejeros, tovo en la primera que con lavores de tierra los quebrantarié más que con otra cosa ninguna, porque es lazeria de grand afán contender con tierra ${ }^{140}$.

Frente a ese relato, no poco hinchado, el historiador judío ${ }^{141}$ presenta, en pocas líneas, a los egipcios como voluptuosos y perezosos para los trabajos, dominados por los demás placeres y sobre todo por la codicia, y añade que, por todo ello, empezaron a estar mal dispuestos hacia los hebreos, por envidia respecto a su prosperidad. Insiste en que maltrataron a los israelitas mandándoles hacer todo tipo de trabajos penosos. No se habla, pues, de fornicio, ni de desear las mujeres hebreas, ni de envidias porque los hebreos comieran con mesura, etc.

Finalmente, a propósito de la expedición de Moisés contra los etíopes que habían invadido Egipto (suceso que no consta en la Biblia), la $G E$ se detiene en la edad del citado:

e veno a edad acabada, que segund dize Josefo es el tiempo de la mancebía, e segund esto tenemos nós que era Moisén estonces de XXX años, ca al tiempo d'agora la edad de XXX años dan los sabios e los santos padres por edad complida, onde veemos

\footnotetext{
${ }^{140} G E$ I.11.4.

${ }^{141}$ AI 2.201-203.
} 
que d'ella judgan los prelados de la santa eglesia de Cristo all clérigo pora ser de ordenar de missa, e otrossí de fazerle abad de abadía acompañada, que es la que á canónigos o monjes, e de fazerle otrossí obispo o aún arçobispo. En que dize Josefo sobre la razón de la edad complida que assí como era Moisén grand cuanto cumplié e fermoso de cuerpo, que assí era otrossí fermoso de bondad e esforçado de coraçón, e que assí lo mostrava él por sus fechos entre los egipcianos. E tenemos nós que en estas razones que oídes que Josefo el sabio dize de Moisén quel da por de edad acabada, e assí lo dize él mismo en el su libro, que por de edad acabada le da en aquella en que él era, e dezímosvos que esta edad es de XXX años, e por quel avién los egipcianos envidia yl querién mal teniénle todos por bueno, ca assí como la estoria dize al bueno an envidia los malos y quieren mal, ca non a los tales como ellos, e assí fazién los egipcianos a Moisén por esta razón ${ }^{142}$.

En cambio, el autor judío nos dice, simplemente, que Moisés «tras haber llegado a la edad visible (eis hélikian phanerán), les dio a los egipcios prueba de su virtud». Digamos que dicha expresión, única en Josefo, sólo tiene un precedente en Aristóteles ( $R h .1379$ a 26), donde la tenemos quizá con otro sentido.

2.29.4.7. Veamos ahora dos errores de bulto y una afirmación dudosa. En primer lugar, en torno a las causas de la torre de Babel, Josefo recoge el presagio de la "Sibila» ${ }^{143}$, sin más explicaciones, pero la $G E$ habla de "Sevilla Cassandra» ${ }^{144}$.

En segundo, durante la salida de Egipto, los hebreos llegaron a un sitio que después se llamaría Babilonia, fundado por Cambises cuando subyugó Egipto ${ }^{145}$ : «E dizen Josefo e maestre Pedro que después d'esto aquel rey de Etiopia que ovo nombre Cambises vino a Egipto, e destruxo toda la tierra e pobló aquella cibdad de cabo, e cuando la poblava esse rey Cambises pusol nombre Babilón, e ésta es a la que dizen Babiloña la de Egipto. E maguer que era yerma estonces, poblada dizen que es agora» ${ }^{146}$.

Y una duda referente a que Josefo vio las dos tablas de la ley: «E cuenta Josefo que él las vío aquellas dos tablas en que Nuestro Señor Dios dio estos diez mandados

${ }^{142} G E$ I.11.35.

${ }^{143} A I 1.118$. Es ésta la única vez en que el término Sibila (en griego, transcrito, Síbylla) aparece en Josefo. La cita del historiador es recogida por Eusebio dos veces (Praeparatio evangelica 9.15.1; Onomasticon, p. 40.16). Las palabras de la citada, en prosa, parecen ser una adaptación de unos versos recogidos en los Oráculos sibilinos (3.97-104).

${ }^{144}$ I.2.21-22. En la literatura griega es rara la asociación Sibila-Casandra: véase Suda, sigma 359. En la $G E$, dicho paralelismo puede haberse debido a la asociación de Casandra con la capacidad de profetizar.

${ }^{145} A I 2.315$.

${ }^{146} G E$ I.12.30. Por lo demás, la $G E$ (I.4.19) habla de Cambises II, rey de Persia; referirse a él como rey de Etiopía, quizá debería entenderse como un título que hubiera adquirido cuando ya había dominado a Egipto ( $G E$ I.11.39). Que dicho monarca tuvo bajo su dominio a Etiopía lo afirma, por ejemplo, Diodoro de Sicilia (1.34.7). 
de la ley a Moisén, e que assí eran escritos en ellas dedentro e defuera como vos contamos que dizen él e los ebreos $\aleph^{147}$. No he encontrado ninguna confirmación de este aserto.

2.29.4.8. En el plano estilístico advertimos la reiteración de menciones de Josefo, posiblemente en busca de un argumento de autoridad. Así, a propósito de los hijos de Cam y Jafet; ${ }^{148}$ de que los hebreos se levantaron contra Aarón y Moisés ${ }^{149}$; sobre las cubiertas del Tabernáculo ${ }^{150}$; sobre el duelo de los hebreos por la muerte de Moisés; de los años que vivió Moisés ${ }^{151}$; del casamiento de Abrahán con Cetura ${ }^{152}$. $\mathrm{y}$ sobre los hijos de Jafet ${ }^{153}$, donde se afirma que los griegos cambiaron los nombres de distintos pueblos; de la adolescencia de José ${ }^{154}$; sobre que José manifiesta ante sus hermanos quién es ${ }^{15}$; del enfrentamiento de Moisés y los suyos contra Sehón, rey de los amorreos ${ }^{156}$; de algunos adornos del Tabernáculo ${ }^{157}$; de las vestimentas hechas para Aarón y sus hijos ${ }^{158}$; sobre que los clérigos quedan librados del ejercicio de armas ${ }^{159}$; de los hijos de Esaú con sus tres mujeres ${ }^{160}$; de cuando Jacob iba a encontrarse de nuevo con su hermano Esaú ${ }^{161}$; de la primera salida de Egipto realizada por Moisés ${ }^{162}$; de los reyes que mandaban cuando Abrahán salió de Egipto ${ }^{163}$; etc.

\subsection{Ptolomeo (1: Tolomeo)}

Claudio Ptolomeo vivió entre los años 100-170 d. C. Ya lo hemos visto en el apartado 2.1.2.

${ }^{147} G E$ I.14.21-22.

${ }^{148} G E$ I.2.27-29. Diecisiete menciones.

${ }^{149} G E$ I.23.13-16. Doce citas.

${ }^{150} G E$ I.16. 21-24. Doce referencias.

${ }^{151} G E$ I.29.22-24. Once citas.

${ }^{152} G E$ i.6.16. Once menciones.

${ }^{153} G E$ I.3.1. Nueve citas

${ }^{154} G E$ I.8.1. Nueve menciones.

${ }^{155} G E$ I.8. 21-23. Nueve citas.

${ }^{156} G E$ I.24.9-11. Ocho citas.

${ }^{157} G E$ I.15.56-58. Ocho alusiones.

${ }^{158} G E$ I.15.78. Siete citas. Con transcripción de nombres del caldeo, hebreo, griego y latín (Cf. Ibid., "La setena vestidura ovo estos tres nombres, segund dize Josefo: en ell ebraigo essin, en el griego logion, en el latín racionali).

${ }^{159} G E$ I.23.19-23. Siete citas en contextos próximos.

${ }^{160} G E$ I.7.44. Siete menciones.

${ }^{161} G E$ I.7.22. Seis citas.

${ }^{162} G E$ I.11.35. Seis citas.

${ }^{163} G E$ I.5.18-19 Seis menciones. Con una referencia histórica al emperador Teodosio. 


\subsection{ORÍGENES $(52)^{164}$}

2.31.1. Su vida se sitúa entre los años 185-254 d. C. Profesor de Teología en Alejandría dio conferencias por diversos lugares del imperio romano, especialmente en Cesarea Marítima (Palestina), siendo muy apreciado por sus exegesis bíblicas. Considerado un padre de la Iglesia oriental y uno de los tres autores esenciales sobre la teología cristiana le interesó a la $G E$ por los numerosos escritos exegéticos dedicados a los cinco libros (desde el Génesis hasta el Deuteronomio) abarcados en la Primera parte de la obra que revisamos, a saber, sus Homiliae (al Génesis, Éxodo, Levítico), Commentarii (sobre el Génesis y fragmentos del correspondiente al Éxodo), Selecta y Adnotationes (ambos conjuntos ricos en estudios especiales dedicados a cada uno de los cinco libros del Pentateuco). Sus obras, todas en griego, se perdieron o fueron mal transmitidas especialmente por el contenido heterodoxo de las mismas, lo que le acarreó numerosos problemas mientras vivió y dificultó, tras morir, la transmisión de sus escritos a la posteridad. Buena parte de ellas nos han llegado en traducciones latinas de Jerónimo y Rufino ${ }^{165}$.

2.31.2. En la primera parte de la $G E$ he encontrado 52 referencias de su nombre. Se le cita sólo a él a propósito de sus comentarios sobre el Éxodo ${ }^{166}$ y Núme$\operatorname{ros}^{167}$. Con más frecuencia se le menciona junto a otros escritores y comentaristas. Procuro mantener un orden acorde con la aparición en la obra: GE I.14.22: «Moisén e Josefo e sant Augustín e Orígenes e maestre Pedro»; I.14.23, junto a Agustín, contra los herejes; I.14.24, donde se le nombra tres veces, al lado de Teodoción y Agustín, en torno al segundo mandamiento; I.14.25, junto a Josefo y Agustín en lo tocante al tercer mandamiento; I.14.26, con los dos citados, respecto al cuarto mandamiento; I.14.27, con los mismos, en punto al quinto; con los nombrados, con referencia al sexto (I.14.28,), séptimo (I.14.29,), octavo (I.14.30) y décimo (I.14.31); I.14.31, con los mismos, en cuanto a discrepancias en el orden de los mandamientos; I.14.33, donde lo leemos tres veces, a propósito de la diferencia en latín entre colere-adorare, al lado de Agustín, Jerónimo, Hugucio (de Pisa), Papías (el lexicógrafo), Ebrardo (de Bethune) y Pedro Coméstor (repárese en las siete fuentes, contando a Orígenes); I.15.53, junto a Josefo y Coméstor, respecto a las cubiertas del tabernáculo; I.15.57, además

${ }^{164}$ Por número de citas ocupa el noveno puesto dentro de la $1^{\text {a }}$ parte de la GE. En torno a su presencia en la GE, véanse Eisenberg, 1973; López Férez, 2014.

${ }^{165}$ Sus obras, muy fragmentarias, pueden leerse en la Patrologia Graeca de Migne (vol.11-17).

${ }^{166} G E$ I.13.23. Respecto a las fuentes y palmeras de Elim; I.14.22, con tres menciones, en torno a la división de los mandamientos; I.14.23, dos referencias, a propósito de qué es un ídolo; I.14.23, en punto a la lealtad entre marido y mujer; I.14.23, dos citas, en cuanto a la relación del demonio con Judas; I.14.32, tres alusiones, donde se insiste en el concepto de ídolo.

${ }^{167}$ I.25.3. La indicación sobre que las mujeres de Madián, más que los hombres, adoraban el ídolo priápico. 
de los dos citados, con Agustín y Beda, en torno a las medidas del tabernáculo; I.15.82, junto a Moisés, Josefo, Jerónimo, Agustín, Coméstor y Godofredo de Viterbo, sobre las medidas del altar del tabernáculo (otra vez, siete fuentes); I.16.21, junto a Josefo, Beda y Coméstor, a propósito de las cortinas del tabernáculo; I.16.21-22, junto a Josefo, en punto a la colocación de dichas cortinas; I.17.1, con Moisés, Josefo, Agustín y Coméstor, en torno a la exegesis sobre el Levítico; I.17.25, de la grasa y la sangre en los sacrificios, junto a Moisés, Josefo, Teodoción, Agustín, Beda y Coméstor (adviértanse las siete fuentes); I.20.6, en punto a las cosas que son santas y la honra al padre y la madre, al lado de Moisés y Josefo, con una larga explicación y aparición tres veces del nombre estudiado; I.20.35, a propósito de las facultades del alma, al lado de Aristóteles, Plinio, Dionisio el exiguo y Agustín; I.21.prólogo, con respecto quizá a la creación de las criaturas, junto a Moisés, los Setenta, Josefo, Teodoción, Jerónimo, Agustín, Beda y Coméstor (nótense las nueve fuentes); I.22.17, sobre doña Tarbe, la etíope, negra, casada con Moisés (una gentil con un hebreo), al lado de Moisés y Jerónimo, con dos apariciones de Orígenes; I.23.22, en torno a los derechos del santuario, junto a Jerónimo, Josefo, Agustín, Rabano Mauro y Coméstor (seis fuentes); I.24.11, al lado de Jerónimo, en punto a cómo los israelitas se apoderaron de Hesbón; I.24.22, exegesis de unas palabras de Balaán, junto a la Biblia hebrea y Coméstor; I.25.16, para comentar lo que quieren decir phase (en hebreo) y "pascua», además de Jerónimo, Agustín, Beda y Rabano Mauro.

\subsection{EUSEBIO (124) $)^{168}$}

2.32.1. La vida de Eusebio de Cesarea transcurrió, aproximadamente, entre el 260/265-339/340. Obispo de Cesarea Marítima, fue exegeta e historiador de la cristiandad. De entre sus numerosas obras la más apreciada por la $G E$ fue el Cronicón (en griego, transcrito, Chronikón), también conocido como la Crónica. El título griego, transcrito, era Pantodapè historía (Historia de todos los países), dividida en dos partes. El original de la primera se perdió, pero las tablas cronológicas de la segunda, los Chronikoì kánones (Cánones cronológicos), fueron traducidas por Jerónimo al latín, constituyendo el Chronicon (Cronicón) de éste ${ }^{169}$, continuación de la obra de Eusebio y punto de partida para numerosos anales realizados en la Edad Media.

En la primera parte de la $G E$ he contado 124 menciones de Eusebio. Haré tres apartados y en ellos seguiré el orden del texto alfonsí. En el primero (2.32.2)

${ }^{168}$ Por número de citas ocupa el cuarto puesto dentro de la $1^{\text {a }}$ parte de la GE. Para su presencia en la GE, cf. Rico, 1972: 20-22; Eisenberg, 1973; Casas Rigall, 1999; Fernández Ordóñez, 1999: 113, 119-120; Almeida Cabrejas, 2009; Salvo García, 2009; López Fonseca-Ruiz Vila, 2019.

${ }^{169}$ Puede leerse, en latín e inglés, también en la red (http://www.tertullian.org/fathers/jerome chronicle 00 eintro.htm). Lo cito simplemente por página, en esta aportación. 
estarán las alusiones sólo a Eusebio; en el segundo (2.32.3), a Eusebio-Jerónimo; en el tercero (2.32.4), a Eusebio con referencias expresas al nombre de otro u otros comentaristas.

2.32.2. En punto a la duración del reino de Asiria (I.3.26), la $G E$ da la lista de los treinta y cinco reyes, desde Nino hasta Sardanápalo; I.3.28: los años que reinó Nino; I.4.19: la lista de los reyes diapolitas de Egipto. Se nos habla de «Eusebio en el libro de las cuentas de los años de las estorias»; I.4.22: de los hijos de Semíramis, a la muerte de Nino; I.4.25: sobre las torres construidas por Semíramis; I.5.32: de la destrucción de Sodoma y Gomorra; I.6.17: en paralelo con los años de Abrahán, lo que sucedía en los reinos de Asiria, Sicíone y Creta; I.12.7. Sobre que Cécrope le puso nombre a Atenas: «e aún, segund diz Eusebio, estonces començó primeramientre la cibdad de Atenas a seer afirmadamientre regno por sí».

2.32.3. En lo referente al comienzo de la tercera edad con la vida de Abrahán, I.4.1; I.4.29: respecto a la muerte de Semíramis, con tres citas del autor revisado; I.5.2: de la promesa de Dios a Abrahán, con dos citas del estudiado: «assí como dize Eusebio en el griego e Jerónimo en latín en el traslado que fizo d'aquella razón de Eusebio»; I.6.18, apuntando al comienzo del reinado de los argivos, con dos citas de nuestro autor y una buena explicación: «E pues que Eusebio, que fue obispo de Cesarea e santo omne, e Jerónimo, otrossí obispo e santo, e que trasladó la Biblia en este nuestro latín, fablan d'estas razones en sus crónicas, querémosvos contar aquí d'ellas, segund las cuentan los autores de los gentiles, e desí diremos en cabo lo que quieren decir»; I.7.5: el ajuste de la cronología histórica a los años de Jacob; I.7.7, lo referente a los reyes pastores de Egipto; I.7.14, paralelo de Ínaco y Foroneo, reyes sucesivos de Argos, con los años de Jacob; 1.7.27: sobre Apis, rey de Argos, con la explicación de que pasó a Egipto y se casó con Isis; I.8.8: cuando José fue encarcelado tras lo ocurrido con la mujer de Putifar, quiénes eran los reyes en los otros países del mundo; I.9.13: sobre los faraones $\mathrm{Nicrao}^{170}$ y Amosis ${ }^{171}$ y el poder de José; I.9.45: acerca de los saberes de Prometeo, cuando José ya llevaba 52 años en el poder; I.10.5: qué reyes había en los demás países del mundo a la muerte de José; I.10.8: respecto a los años que Jacob vivió en casa de José, en Egipto; I.10.9: respecto a los 214 años que duró la servidumbre de los hebreos en Egipto; I.10.13: en punto a los 74 años desde la muerte de José hasta el nacimiento de Moisés y el silencio de la Biblia sobre los mismos;

${ }^{170}$ Según la GE, I.8.5, dicho faraón hizo muchas conquistas y llegó incluso a España, donde luchó contra «el rey Rodrigo el menor». En los años de Nicrao tuvieron lugar los sucesos principales de José (la venta, lo ocurrido con la mujer de Putifar, el alto cargo ocupado en el reino, etc.). Su hijo y sucesor se llamó Amosis: GE I.9.13.

${ }^{171}$ José continuó ocupando sus altos cargos durante el reinado de este faraón: $G E$ I.9.14. Figura como Amasis, en Jerónimo, pp. 42-43. 
I.10.39: acerca de los curetes y coribantes y cómo poblaron Cnoso. Además una etimología sobre los coribantes, basada en el latín; I.10.41: de los faraones Achor y Cencres ${ }^{172}$, así como el rey Cécrope de Atenas; I.11.30: Amram, padre de Moisés, cumplió 70 años cuando éste nació; I.11.31-32: del faraón Horo y de los reyes coetáneos en otros países. Mención del primer Hércules, el que pasó de Grecia a África; I.11.33-34: sobre los cuatro Hércules que hubo y sus épocas. Contamos cinco menciones tanto de Eusebio como de Jerónimo; I.11.49. A propósito de los 40 reyes de Atenas; I.11.54: Moisés, a los 42 años, se retiró al desierto para filosofar; I.12.5. De los faraones Cencres (el que murió en el mar cuando perseguía a los hebreos en su salida de Egipto) y Acherres; I.13.16-17. Acerca del faraón Cencres y los reyes coetáneos en otros países, como Erisictonio, rey de Atenas, y, además, Hércules «Desanao» ${ }^{173}$, «el sabio». Leemos una etimología atrevida: «fue dado en Grecia un logar pora oír todos los pleitos e librarlos, e a aquel logar establecido pora aquesto pusiéronle nombre Ariópago; e lieva este nombre de ares, que dizen los griegos por lo que nós en el lenguage de Castiella dezimos virtud o virtudes»; I.14.prólogo y 1: de los nombres de los faraones, Cencres, el que persiguió a Moisés y murió por tal causa, y Acherres ${ }^{174}$, su sucesor. Asimismo, cómo se llamaban en las historias de Egipto; I.25.24: que a los 25 años del caudillaje de Moisés, Esténelo, buen rey, mandaba en Argos, y durante su reinado le llegó Dánao «pobre e lazrado, e fuyendo»; I.25.26: que Dánao y Egipto («Danao e Egisto») tuvieron respectivamente cincuenta hijas y cincuenta hijos, y vivían "en Assiria ant'el rey Nino, su hermano» ${ }^{175}$, pero no cabían allí tantos y decidieron irse a Grecia. Y, según Eusebio y Jerónimo «que non es de maravillar, e mayormientre entre las yentes bárbaras ó ellos eran e fizieron aquellos fijos, ca diz que podrié allí aver cadaún varón mugieres amigas cuantas quisiesse no hay que extrañarse de tantos hijos e hijas».

${ }^{172}$ Constan, respectivamente, como Athoris y Chenchres en Jerónimo, pp. 60-61.

${ }^{173}$ Mencionado seis veces en la parte que hemos revisado. Cf. Jerónimo, pp.62-63: Hercules cognomento Desinaus in Phoenice clarus habetur: unde ad nostram usque memoriam Cappadocibus et Heliensibus Desinaus adhuc dicitur, que puede traducirse: «Hércules, con la denominación Desinao, es considerado famoso en Fenicia. Y, por eso, hasta nuestra memoria, es llamado Desinao todavía por los capadocios y eleos». El sobrenombre Desinaus ha suscitado muchas variantes en la tradición exegética: se le ha leído como Desanaus, Doseneus, Desonaus, etc. Puede ayudar a entenderlo lo que tenemos en Jorge Sincelo, Ecloga chronographica, p. 180.6: «Afirman algunos que Heracles es conocido en Fenicia, llamándosele Disandán, como así es denominado hasta ahora por los capadocios y eleos». Podría tratarse de una cita tomada del Cronicón de Eusebio, autor que Sincelo cita 141 veces en su Ecloga, y al cual menciona tres líneas más arriba del texto traducido. Hay otro problema, no menor, no resuelto: Disandán es un hápax en la literatura griega, según el TLG on line.

${ }^{174}$ Figura, tal cual, en Jerónimo, pp.62-63.

${ }^{175}$ En Jerónimo, pp.16-17, leemos que Nino, hijo de Belo, fue el primero en reinar sobre toda Asia, excepto India, durante 52 años. Según el escolio a Esquilo, Pr. 773-4, de Ío (la hija de Ínaco, amada por Zeus), nació Épafo; de éste, Libia; de ésta, Belo; de éste, Dánao. Para muchos, hijos de Libia fueron Agenor y Belo; hijos de éste fueron Egipto y Dánao. Pero conocemos otras versiones, menos corrientes. Así, Tzetzes, Chiliades 7.116, dice que «hijos de Belo fueron Nino, Agenor, Fénix, Egipto, Dánao y Fineo». 
2.32.4. Con respecto a los saberes de los de Babilonia (I.3.25), se recurre al Panteón (de Godofredo de Viterbo), «Eusebio en su Crónica» y Cicerón al comienzo de su primera Retórica; I.3.30: sobre los cuatro reinos principales del mundo, Eusebio aparece junto a Orosio y Coméstor; I.3.31, acerca del reino de Sicíone, tenemos ocho citas de Eusebio en poquísimo espacio, y, además, Jerónimo y Coméstor; I.4.21: respecto a que Nino venció a Zoroastro, Eusebio es citado junto a Godofredo; I.4.30: en punto al reinado de Cres en Creta y otros asuntos de esta isla, hallamos tres citas de Eusebio, junto a Godofredo; I.5.25, sobre la llegada de los hebreos a la tierra prometida, leemos «assí como cuenta Eusebio e otros muchos»; I.6.16, en torno a Abrahán y sus hijos, se nos indica "como las dizen Eusebio e maestre Pedro e otros»; I.6.28: tocante a Ínaco, Ío y el paso del Bósforo, con una etimología no muy desacertada («Ínaco, el río de la cibdad de Argos de Grecia es llamado Bosfor de Ílo su fija del rey, e compusieron este nombre Bosfor de bos, que dezimos los latinos por vaca e por buey, e foros que dize el griego por levar, porque aquel río e aquella mar levaron e passaron a Ío de Grecia a Egipto. E es Bosforo cosa de que fabla el Plinio e otros muchos sabios»), se alude a Plinio, con dos citas del autor revisado, más Jerónimo y Lucas (sc. de Tuy, es decir, el Tudense); I.6.32, a propósito de la muerte de Abrahán, Eusebio está al lado de Josefo y Jerónimo; I.6.33, con referencia a la muerte de Ismael, se cita el apoyo de Eusebio, además de Jerónimo, Coméstor y «la estoria de Egipto»; I.7.17: en punto a que durante los años de Jacob tuvo lugar un levantamiento contra Foroneo, se menciona a Eusebio junto a Jerónimo y Orosio; I.7.24, en lo relativo al rey Ogiges y el nacimiento de Palas («e los griegos llámanla Minerva»), se recurre a Eusebio, y, asimismo, a Jerónimo y Lucas de Tuy; I.7.30: respecto a los años que vivió Isaac, se busca el apoyo de Josefo y Jerónimo; I.7.42, a propósito de la Edad de oro, con recurso a Cicerón, Ovidio, Jerónimo y las «estorias de Rocas» ${ }^{176}$; I.7.43: sobre la unión de Júpiter ${ }^{177}$ y Níobe, padres de Dárdano y Tros, se acude a Eusebio, junto a Jerónimo y Godofredo; I.8.5: en torno a que cuando José fue vendido, reinaba en Egipto el diapolita Amosis, se recurre, además de Eusebio, a Orosio, Segeberto de Gembloux y Godofredo; I.9.16: respecto a quiénes eran los reyes en los países del mundo cuando José tenía 50 y 20 años, se busca apoyo, además, en Jerónimo y Ovidio; I.9.42: tocante a Deméter y las medidas de las mieses y del vino y el aceite, así como los reyes de los países del mundo, se consulta, asimismo, a Jerónimo y Godofredo; I.10.10: en punto a otras cuentas de los años de servidumbre de los hebreos en Egipto, con las discrepancias entre Josefo (400 años)

${ }^{176}$ Sobre este curioso personaje, tenido por hijo de un rey, procedente de India y que anduvo por el mundo buscando los saberes, y que llegaría a ser el fundador de Roma según noticias sacadas de una fuente desconocida, quizá árabe, véase Fernández-Ordóñez, 1992: 94.

${ }_{177}$ A propósito del mismo leemos: «ca este rey Júpiter fallamos que fue el rey d'este mundo fasta’l día d'oy que más fijos e más fijas ovo, e condes de muy grand guisa todos los más, e reínas». Con respecto a Júpiter en la GE, Rico, 1972: 97-120; Fraker, 2000; Salvo García, 2010b. 
y Eusebio-Jerónimo (430), se contrastan Josefo, Eusebio (con tres citas), Jerónimo y Lucas de Tuy; I.10.16-17: sobre los faraones se indica lo siguiente: «e esto ál dizen Eusebio e Jerónimo, que son santos e sabios de creer; el segundo faraón, segund Eusebio e Jerónimo otrossí, fue Chebrón; el tercero Amenofes; el cuarto Mefres; el quinto este Misfarmotosis ${ }^{178}$, pero se consulta también la Historia de Egipto, como discrepante; $y$, asimismo, a Coméstor, en lo pertinente al último faraón mencionado; I.10.21: a propósito del monte Atlas, cf. nuestro apartado 2.5, referido a Eurípides; I.10.30: respecto a los reyes coetáneos de Atlas como rey del Algarbe de España y de África, se lee lo que recogen Eusebio «e Lucas en el Libro de la estoria de Troya» ${ }^{179}$; I.10.33: para comprobar que Moisés nació en los años del faraón Amenofes, hijo del faraón Tamoso ${ }^{180}$, la GE se apoya en Eusebio, Jerónimo, Lucas de Tuy, Coméstor y Godofredo; I.10.34-37, con alusión a Tamoso y los reyes coetáneos en otros países, se recurre a Eusebio (cinco citas), Jerónimo y Godofredo: «E assí como cuentan las crónicas de Eusebio e de Jerónimo, aquellos cuatro reyes faraones que regnaron en Egipto en aquel tiempo que dezimos fueron éstos por sus nombres segund la fabla egipciana: el primero Mefres, en cuyo regnado finó Josep tres años por andar d'él; el segundo Misfarmotosis, que regnó XXVI años; el tercero Tamoso, IX años; el cuarto d'ellos fue Amenofes»; I.11.3: en una discusión sobre el faraón Amenofes, según los distintos autores, se busca la autoridad de Eusebio (dos citas), Jerónimo, Lucas de Tuy, Coméstor y Godofredo; I.12.7: en lo sucedido cuando Moisés regresó a Egipto, y, además, los hechos del rey Cécrope de Atenas, procedente de Egipto, se busca el criterio de Eusebio, Jerónimo y Lucas de Tuy; I.12.8: sobre lo que Moisés habló con el faraón Cencres, son citados Eusebio, Jerónimo y Josefo; I.12.31: en alguna ocasión se busca también la autoridad conjunta de Eusebio, Jerónimo y los relatos arábigos: «E dize un sabio de los arávigos que ovo nombre Alguazif ${ }^{81}$, e escrivió las estorias de Egipto, que a este Faraón en cuyo tiempo esto conteció e que iva empós los ebreos quel llamavan Talme en arávigo, e en ebraigo Talmai, e los egipcianos, segund cuentan Eusebio e Jerónimo, le dizién Cencres, como vos avemos nós ya dicho. E avié una fija quel dizién Munene; e este nombre Munene quiere dezir en arávigo tanto como en el nuestro lenguage de Castiella lo que desseamos»; I.13.6: a propósito de

${ }^{178}$ En Jerónimo constan, respectivamente, como Chebron, Amenophis, Mephres y Mispharmuthosis, pp. 44-49. En Teófilo de Antioquía, Ad Autolycum 3.19, leemos que el faraón que expulsó a los hebreos fue Téthmôsis. Además, sus sucesores fueron Chebrôn, Aménōphis, la hermana de éste Améssē, Mếphrēs y Mēphramoúthōsis.

${ }^{179}$ Una obra de Lucas de Tuy que no nos ha llegado. Cf. J. Casas Rigall, 1999: 202.

${ }^{180}$ En la parte estudiada de la $G E$ aparece como Tamos (cf., por ejemplo, GE I.10.18) o Tamoso. Era hijo de Misfarmotosis (GE I.4.19; I.10.32; etc.). Para la lista de los 36 faraones diapolitas, cf. GE I.4.19.

${ }^{181}$ La obra de Alguazif se menciona por vez primera en la General Estoria al principio del Éxodo ( $G E$ I.12.31), pero pudo haberse consultado también en el Génesis para algún detalle como el nombre del faraón: se titula Estoria(s) de Egipto. Es fuente esencial para los faraones y la historia de Egipto. Cf. Fernández-Ordóñez, 1992: 180-181. 
que el faraón de Moisés y el de José eran distintos, la $G E$ acude a Eusebio y Jerónimo contra ciertas fuentes arábigas; I.13.14: sobre el incendio de Etiopía por causa de Faetón, y cuándo sucedió, se recurre como fuentes a Platón, Orosio, Eusebio y Jerónimo; I.13.15: en torno a incendios, terremotos y pestilencias acontecidas en otros lugares, aparte de Egipto, la obra alfonsí menciona a Platón, Eusebio, Jerónimo, Orosio y Lucas de Tuy; I.14.16: sobre quiénes eran los sacerdotes, la $G E$, aparte de Eusebio y Jerónimo, acude a Coméstor; I.14.36: en las discordancias causadas por algunos antropónimos se busca el respaldo de Eusebio y Jerónimo ( $\mathrm{E}$ fallamos muy grand desviamiento en los nombres de los faraones que esta estoria de Egipto pone de los que leemos que ponen en sus crónicas Eusebio en el griego e Jerónimo en el latín»), así como el de ciertos autores arábigos, y se recurre, además, a «Precián en el su Libro mayor» ${ }^{182}$; I.21.3: en la cronología del mando de Moisés vista en paralelo con los reyes de otros países, y a propósito de Arcas, rey de Arcadia, hijo de Júpiter y Calisto, se busca apoyo, además de Eusebio y Jerónimo, en Ovidio; I.21.29: con referencia a que Perseo, rey de grandes hechos, sería coetáneo de los años de Moisés cuando estaba con los ganados de Jetro, la $G E$, además de contar con el criterio de Eusebio y Jerónimo, se apoya en el Panteón de Godofredo; I.22.11: el año en que Moisés partió del Sinaí hacia Canaán se considera fecha clave para la cronología universal y la de los reyes de otros países. En Egipto reinaba el faraón Acherres, según Eusebio y Jerónimo, pero se trataría de la reina Doluca ${ }^{183}$, de acuerdo con la «Estoria de Egipto»; I.23.26: al faraón llamado Cencres en Eusebio y Jerónimo, la mencionada Historia de Egipto lo denomina Talme, y a su muerte sucedió lo referente a la reina Doluca, la cual «endereçó su regno»; I.29.22: en punto a que Moisés vivió 120 años, se recurre a Josefo, Eusebio, Jerónimo y Coméstor.

\section{AUTORES DE LA LITERATURA LATINA ${ }^{184}$}

Hemos revisado dentro de la $G E$ (Primera parte) la recepción de autores latinos desde el siglo III a. C. (periodo republicano) hasta mediados del v d. C. (periodo postclásico). Nuestro estudio deja pues abierta la investigación para la presencia en la obra alfonsí de escritores en latín correspondientes al periodo medieval (siglos VI-hasta el XIII, es decir, los años de la redacción de la $G E$ ).

${ }^{182}$ A saber, Prisciano (500-530 aprox.) y sus Institutiones Grammaticae.

${ }^{183}$ El nombre parece proceder de Les Prairies d'Or, traducción francesa del tratado escrito en el siglo X por Mas 'üdí, especialista en el género geográfico-enciclopédico dentro del mundo musulmán. Cf. Fernández-Ordóñez, 1992: 176. 1990, 1994.

${ }^{184}$ Cf., entre numerosos estudios, Badía Margarit, 1958-1959; Sánchez-Prieto Borja, 


\subsection{VARrón (7: Marco Varro, 4; Varro, 3)}

Su vida transcurrió entre los años 116-27 a. C. Plinio lo menciona en numerosas ocasiones (142 citas). Casi las seis apariciones de dicho autor en la parte de la $G E$ estudiada corresponden, en realidad, a alusiones sobre el autor de la Naturalis Historia, la cual, como veremos al llegar a su estudio, tuvo importancia relevante en el texto alfonsino. Veamos las citas referentes a Varrón. Empezamos por la fundación de una ciudad en el Capitolio romano a manos de un hijo de Hércules: «Un fijo de Hércules, e llamal aquel Libro de las maravillas de Roma ${ }^{185}$ fijo de Hércules, e non fallamos d'él otro nombre, vino con los de la cibdat de Argos de Grecia allí a aquel regno de Jano, e pobló ý so el Capitolio una cibdat, e pusol nombre Valeria, así como diz Varro, que fue grand sabio de estorias. E este nombre Valeria semeja que fue tomado d'esta palabra valencita fascas de fuerça, e puesto a aquella cibdat» ${ }^{186}$. Acerca de los nombres del Tíber leemos así: «Vino aquel rey Itallo e lidió allí con este rey Tibre, e mató Italo a Tibre en la fazienda en aquel río. E d'aquí dizen Virgilio e Varro que ovo este río Albula de Roma este nombre Tibre d'aquel rey Tibre que murió en él $»^{187}$.A propósito de las serpientes venenosas se nos dice lo siguiente: «E dize otro sabio que llamaron Varro que del linage d'estos omnes á ý aún, mas son pocos, e aun diz que éstos con la saliva sola sanan los feridos de las serpientes; tal natura an contra ellas» ${ }^{188}$. Después, encontramos un elogio de los asnos, su naturaleza, su elevado precio en Roma, con el ejemplo de Quirino Axio, senador de Roma, que compró uno por mucho dinero porque era animal muy útil y muy sufridor de muchas dificultades, excepto el frío ${ }^{189}$; se nos explica cuándo y cómo queda preñada la asna y cómo se retira a lugar escondido cuando le llega el momento de parir, y cómo no le gusta beber en aguas desacostumbradas; el aprecio que se les tenía a los asnos y el elevado precio de esos animales en España ${ }^{190}$, así como la máxima de que más vale tener un asno que una buena herencia ${ }^{191}$. Con referencia a las clases de lana y del arte de tejer con ella, la $G E$ acude a Plinio y menciona cómo Varrón habla de una toga de lana tejida por la reina Tanaquil, luego llamada Gaia Cecilia, y cómo Servio Tulio, rey de Roma, la

${ }^{185}$ A. G. Solalinde, 1936: 113-142, identificó las Graphia aureae urbis Romae como el Libro de Roma o Libro de las noblezas e marauillas de Roma, presente en la General Estoria. La obra Graphia... fue publicada por C. L. Ulrichs, 1871. Cf. Fernández Ordóńez, 1989: 31.

${ }^{186} G E$ I.3.22. No he localizado en Varrón nada semejante.

${ }^{187} G E$ I.3.22. Plinio, HN 3.53 menciona ese cambio de nombre. Consúltense, además, Varrón, De Lingua Latina 5.30.4; y Virgilio, Eneida 8.332.

${ }^{188} G E$ I.8.15. Se basa en Plinio, HN7.12.

${ }^{189}$ Dice el naturalista que, por esa razón, dicho animal no se cría en el Ponto. En Alfonso (I.20.24), en cambio, se indica que "por esto non á asnos en Escocia nin en ninguna otra tierra que sea muy fría como aquélla».

190 "Celtiberia» en Plinio.

${ }^{191} G E$ I.20.24, donde leemos dos menciones de Varrón. La cita procede de HN 8.167-170. 
llevó puesta y, asimismo, que, después, la citada prenda quedó expuesta en el templo de la Fortuna («Aventura», en el texto alfonsí) ${ }^{192}$.

\subsection{Cicerón (8: Tullio)}

Vivió entre los años 106-43 a. C. La GE, primera parte, siempre lo llama "Tullio» ${ }^{193}$, y, en la sección aquí revisada, lo cita exclusivamente a propósito de las costumbres de los primeros hombres: «Pues salvo ende estos de la liña e pocos otros todos eran de comienço tales como avemos dicho, e bivién más a maneras de costumbres de bestias que non de omnes, assí como cuenta Tullio en la su primera Rectórica, e otorgan con él muchos otros sabios. Ca luego que avién fambre e sed comién e bevién cada que les tomava ende sabor, como fazen agora e fizieron siempre las otras animalias, que nin entienden nin an razón de se guardar ende» ${ }^{194}$. Esta afirmación la leemos en otros contextos:

E por esso lo avemos nós dicho ya, e sobr'esso leémoslo en la setena parte del Panteón, e dízelo Eusebio en su Crónica, e Tullio en el comienço de la su Primera rectórica, que en tiempo d'este rey Nino que las yentes más vivién como bestias que como omnes, e si ovieran pueblas que las non avién pora acompañarse, e si buenas costumbres non pora onrarse d'ellas unos a otros, e si algunas leyes o fueros non pora usar d'ellos por aver derecho entre sí nin fazer justicia, mas que assí se andavan todos a suelta por las tierras e por los montes como los ganados sin guarda, o como las animalías bravas por los yermos; ca dizen que de las artes de los saberes e de la filosofía non sabién aún estonces nada, nin aun el nombre d'ellas solamientre, quel non sabién nil avién aún oído, que era ya menos [...] E las yentes de las tierras, porque eran aún estonces tan necios como avedes oído, que nin casavan aún por ley nin avién mugeres coñoçudas por suyas apartadas cadaúno la suya, nin fijos ciertos, nin armas pora lidiar, nin sabién ellos ende nada, nin lidiavan si non así como dize Tullio, que peleavan como las otras animalias, como el puerco montés con el puerco, el toro con el toro, e el león con el león, e ell águila con el águila, e non tenién ellos guisado de cometer ellos a otre, nin aun de defender a sí mismos ${ }^{195}$.

Y, en otro lugar:

[...]ca nós avemos dicho ante d'esto[...] como cuenta Tullio en el començamiento de la su primera Rectórica, que los omnes del primero tiempo assí se andavan por

${ }^{192} G E$ I.20.28, con dos citas del autor revisado. El texto procede de $H N$ 8.194.

${ }_{193}$ Para algunos aspectos de la presencia del orador y retórico en Alfonso X y en la GE, cf. Eisenberg, 1973; Díez de Revenga, 1988; Montoya Martínez, 1995; Fraker, 2006.

${ }_{194} G E$ I.3.10. El pasaje corresponde a Cicerón, De inventione 1.1.2-3 (= Rhetorici libri duo qui vocantur De inventione).

${ }^{195} G E$ I.3.25. Dos citas del autor romano. Cicerón, contra lo que pudiera deducirse del texto alfonsí, no menciona nunca a Nino. La $G E$ es con frecuencia imprecisa sobre la autoría de una afirmación, pues enlaza, a veces, una oración con una persona mencionada anteriormente, sin solución de continuidad, surgiendo no pocos equívocos a causa de dicha distribución sintáctica. 
las tierras e por los montes como bestias salvages, que assí comién e bevién e tal vida fazién, e que nin avién tierras nin viñas, nin casas nin heredad nin otra cosa coñoçuda ninguna nin se trabajavan d'ello, nin moravan en uno, nin levava ninguno a otro a fuero nil trayé a pleito nin en juizio, nin avién por qué sobr'esta razón, ca todas las cosas eran comunales entr'ellos. Despues d'esto diz que vino un omne sabio e fízolos morar en uno, e entender el mundo, e aver leyes por que visquiessen, e sacólos d'aquella neciedad en que fueran fasta allí, e fízolos entendudos e sabios. Mas non pone el nombre d'aquell omne, e puede seer que éste fue el rey Júpiter ${ }^{196}$. Y, de nuevo: «E por estas simplicidades que avié en las yentes del primero tiempo dizen que les levavan los árvoles muchas frutas e criávales la tierra muchas buenas yervas e otras cosas de que comién ellos estonces e vivién. En estas razones de Tullio e de Ovidio [... $]^{197}$.

\section{Y otra vez:}

E fallamos que d'esta razón tomaron algunos por que dixieron que casamiento en todo tiempo fue, peró que vos aduxiemos nós prueva de Tullio[...]; que dize Tullio en el primero libro del su enseñamiento de fablar apuesto que los omnes en el primero tiempo nin avién mugeres coñocudas nin fijos que coñociessen por suyos [...]; e otrossí [...] verdad es de lo que dize Tullio de las yentes cuáles eran en el comienço en esto e en las otras costumbres, ca muchos otros sabios fallamos que otorgan con ellos que tales eran las yentes estonces cuales ellos dizen ${ }^{198}$.

\subsection{Virgilio (5) 199}

Su vida se sitúa entre los años 70-19 a. C. Lo hemos visto ya en el apartado 2.6, a propósito de Atlas. También en 3.1, respecto al nombre antiguo del Tíber. Veamos, pues, los otros tres lugares. En primer lugar, lo hallamos al hablar de los primeros hombres: "E salieron de las choças, e moravan en tiendas que levavan de logar en logar con sos ganados. E a estas tiendas dize en latín magalia, e es magale casa pastoril fascas de pastor, assí como diz Virgilio en el libro a que dizen Bucólica, ó fabla él de los pastos e de los ganados» ${ }^{200}$. Otra mención la leemos con respecto al trípode.

${ }^{196}$ GE I.7.42. Cicerón, en De inventione, lugar ya mencionado, habla de un hombre sin duda superior y sabio (quidam magnus videlicet vir et sapiens), que descubrió las cualidades que existían en los hombres y su capacidad para realizar grandes empresas gracias a la instrucción (praecipiendo), y por eso reunió en un solo lugar a los que estaban dispuestos a llevar a cabo actividades útiles y dignas.

${ }^{197} G E$ I.7.42.

${ }^{198} G E$ I.20.3. Nótense las tres menciones del escritor romano en un contexto reducido.

${ }^{199}$ En torno a la presencia de Virgilio en las obras históricas de Alfonso X, cf. Rico, 1972: 170-174; Díez de Revenga, 1988; Casas Rigall, 1999: 19 (con buena información sobre la presencia de Virgilio en la literatura española), 109, 239, etc.; Bizarri, 2019: 77-78.

${ }^{200} G E$ I.3.12. En Virgilio figura magalia en dos ocasiones. Se trata de la Eneida, 1.421; 4.259, pasajes bien comentados por Servio. No consta, en cambio, en las Bucólicas. 
Precisamente en relación con la bíblica Rebeca, se recoge lo que ésta hizo con el laurel: «que se puso allí so la cabeça a aquella manera del árvol laurero a que los gentiles llamavan tripoda, e era estonces tripoda, assí como fallamos en los autores de los gentiles Virgilio, Ovidio, Oracio e otros, una mesa de tres pies sobre que ell ídolo del Sol e de Júpiter, que eran los mayores dioses que ellos avién, davan las sus más ciertas respuestas a sos romeros e a los pueblos que les vinién a demandar sus dubdas que les acaecién ${ }^{201}$. La tercera cita está relacionada con los caballos: «Cuáles cavallos e de cuáles fechuras se deven escoger por mejores Virgilio lo muestra, e cuéntalo otrossí Plinio en el libro de la lid de los cavalleros ${ }^{202}$, e vemos que muchos son los sabidores que los conocen bien ${ }^{203}$.

\subsection{Horacio (3: Oracio) $)^{204}$}

Su vida trascurrió entre el 65 y el 8 a. C. Lo hemos encontrado ya dos veces: en los apartados 2.6 y 3.3. Un tercer testimonio hace referencia al río Ladón:

E diz que este río Ladón corre por medio de Grecia, e que es río de muy buena agua muy clara e muy sana, e á muchas cañaveras por todas las riberas d'él, e allí a aquella ribera muestra que vinieron todos los filósofos de Grecia a estudiar sobre las siete

${ }^{201} G E$ I.7.2. Efectivamente, tripus, -odis, aparece, por ejemplo, en Virgilio, Eneida 3.360, 5.510, 9.265; Horacio, Carmina 4.8.3; Ovidio. Her. 3.32, Fast. 3.855, Ars 3.789; etc. El término alude, entre otros valores, al instrumento de tres patas desde el que la Pitia délfica pronunciaba sus oráculos. A partir de Calímaco (Fr.194.26) tenemos la noticia de que la profetisa se sentaba sobre el propio laurel, desde el que emitía sus mensajes; véase, asimismo, Diodoro de Sicilia, 16.25.3. Los primeros autores que mencionan al citado personaje son Eurípides y Heródoto. Por su lado, en sus Moralia, Plutarco aporta numerosas indicaciones sobre el funcionamiento del oráculo délfico y las actividades de la Pitia. El laurel (dáphnē, en griego; relacionado con el personaje mítico homónimo) era el árbol consagrado a Apolo y estuvo desde siempre muy vinculado con el oráculo délfico. Así, Luciano (Bis accusatus 1) indica que la profetisa había mascado laurel cuando llamaba a Apolo para que se presentara en el recinto.

${ }^{202}$ La obra alfonsí se apoya en HN 8.162: forma equorum, quales maxime legi oporteat, pulcherrime quidem Vergilio vate absoluta est; sed et nos diximus in libro de iaculatione equestri condito, et fere inter omnes constare video. Efectivamente, entre las obras perdidas de Plinio, figuraba un De jaculatione equestri (es decir, sobre el lanzamiento de la jabalina montado a caballo).

${ }^{203} G E$ I.20.22. Si nos limitamos al término equus, presente 10 veces en Virgilio, tenemos algunos textos valiosos sobre los mismos en $G$. 2.145, 3.499. Por su lado, de las 8 ocasiones en que está registrado en la $H N$ de Plinio, varios pasajes aportan distintos enfoques sobre ese animal: 8.142.155, 28.146, 35.95. En el libro octavo (8.142-147) hay numerosas noticias sobre caballos importantes: los de Alejandro, César, Augusto; se destaca la docilidad e inteligencia de dicho animal y se hace referencia a las carreras de carros; el naturalista se detiene en cómo es la generación del caballo y sus enfermedades; refiere que las yeguas se quedan preñadas por efecto del viento cerca del Tajo (en la actual Lisboa); alude a los caballos asturcones; etc. No obstante, la cita clave es la indicada en la nota anterior.

${ }^{204}$ Para la presencia del autor en las obras históricas de Alfonso X, véanse Rico, 1972: 163; Díez de Revenga, 1988. 
artes liberales. E, assí como dize Oracio e las glosas de sobr’él comién allí los filósofos muy poco pan, e de las raízes de las yervas que fallavan por ý, e bevién del agua d'aquel río, e allí estidieron fasta que apuraron aquellos siete saberes e los pusieron a cadaúnos en sus reglas ciertas ${ }^{205}$.

\subsection{Ovidio (76)}

Vivió entre los años 43 a.C.-17 d.C. Lo hemos visto ya en los apartados 2.3, 2.32.4 (3 veces), 3.2 y 3.3. Antes de pasar a las otras alusiones del citado en la $G E$, conviene decir algo sobre la importancia de ese poeta latino ${ }^{206}$ para la mencionada obra alfonsín ${ }^{207}$, en la que se traducen al castellano las Heroidas ${ }^{208}$, se vierten pasajes selectos de las Metamorfosis (llamado "el Libro Mayor», en Alfonso; también se le cita como «el Ovidio Mayor») y se utilizan con frecuencia los numerosos tratados exegéticos medievales dedicados especialmente a esta última obra ovidiana. Recogeré ahora lo esencial de las secuencias alfonsíes siguiendo el mismo orden en que aparecen dentro de la Primera parte de la obra referida. Así, en torno a los Gigantes, leemos: «E esta torre puñavan ellos en fazerla tan alta non tan solament pora ampararse en ella del diluvio, mas por llegar tanto al cielo que pudiessen alcançar por ý los saberes de las cosas celestiales, e aun segund cuenta Ovidio en el primer libro de los quinze

${ }^{205} G E$ I.6.28. No he hallado fuentes clásicas que avalen lo afirmado en la Estoria. El río Ladón (en latín Ladon, -nis) aparece, en cambio, en varios autores de la época clásica romana: Ovidio, Plinio, Séneca, etc.

${ }^{206}$ Por número de citas ocupa el sexto puesto dentro de la $1^{\text {a }}$ parte de la $G E$, siendo el único poeta que figura en lugar tan relevante. En la parte estudiada, son las Metamorfosis (así se la denomina en una ocasión: GE I.7.42) y las Heroidas las dos obras ovidianas más mencionadas, especialmente la primera. Otros escritos aludidos son Fastos (o Faustos, o Libro de los fastos) y Remedios de amor (GE I.21.16: «E Ovidio otrossí en el libro de las sanidades dell amor a que llaman Ovidio De remedio amor»).

${ }^{207}$ Sobre la tradicion medieval y renacentista de las obras de Ovidio, es imprescindible el libro de Coulson-Rey, 2000. Por su lado, Fernandez Ordóñez, 1999: 105-114, ha demostrado que el trabajo de las escuelas alfonsíes duró desde 1250 hasta la muerte del rey sabio, y que hacia 1270 se gestó el proyecto concreto de redactar tanto la Estoria de España como la General Estoria. Las traducciones realizadas (Lucano, Orosio, Pablo Diacono, la Biblia, el Pantheon de Godofredo de Viterbo, etc.) fueron incorporadas en las redacciones de ambas historias. Indicios evidentes (la historia de Hércules, el episodio de Dido y el reino de Cartago, así como varios más) muestran que las dos obras recurren a las mismas traducciones de las fuentes (entre ellas, Plinio, Ovidio, Lucano, Pompeyo Trogo-Justino, Orosio, EusebioJerónimo, Sigeberto de Gembloux, Lucas de Tuy, Hugucio, Jiménez de Rada). Cf. de la misma autora, 1993. La bibliografía sobre la presencia e influencia de Ovidio en la General Estoria es muy amplia. Recojo sólo la más relevante: Solalinde, 1915; 1928; 1934; 1936; Lida de Malkiel, 1958; 1959; Ginzler, 1971; Rico, 1972; Eisenberg, 1973; Impey, 1980; Coulson - Roy, 2000; Cuesta Torre, 2007; Cristóbal, 2011; Salvo García, 2010a, 2010c, 2012, 2014; Ekman, 2013; López Férez, 2015; etc.

${ }^{208}$ Llamado en la $G E$ «El Libro de las Dueñas», o «Epístolas de las Dueñas». Entre muchos trabajos dedicados a su presencia e influencia en la General Estoria, véanse Ashton, 1944; Brancaforte, 1990; Garrido, 1991; Puerto Benito, 2008; Salvo García 2009. 
del su Libro mayor que los llamava ý gigantes, su voluntad era de echar ende a los dioses, fascas a los ángeles, e seer ellos ende señores ${ }^{209}$. Respecto a la Torre de Babel, los Gigantes y su intento de poner el monte Pelión sobre el Osa, Tifoeo, los planetas y la metamorfosis de los dioses, tenemos un largo pasaje donde se citan varios versos en latín (Met. 5.86-90) ${ }^{210}$, con alusiones también a Agustín y Godofredo. A su vez, se enlaza la referencia a la reina Semíramis, respecto a los muros que mandó hacer con ladrillos de tierra, con el relato de lo ocurrido a Píramo y Tisbe ${ }^{211}$. Al hablar del rey Ínaco de Argos, la historia alfonsí se ocupa del río llamado como ese monarca, y, en especial, de Ío, la hija del mismo. El enamoramiento de Júpiter y cómo éste logró unirse con ella; cómo Juno lo advirtió, con la tranformación de Ío en vaca, y cómo la reconoció el padre de la indicada por las letras que con la pezuña hizo en tierra, y cómo Juno dispuso que Argos la vigilara con sus cien ojos, así como la muerte de éste a manos de Mercurio por orden de Júpiter, y cómo Ío llegó a Egipto donde fue considerada diosa ${ }^{212}$. En punto al nombre de «Atenas» se nos dice:

E ovieron respuesta en doze d'aquellos ídolos quel pusiesen nombre Atenas, e assí la llamaron d'allí adelant. E por esso diz Ovidio en el su Libro mayor que Atenas quier dezir tanto como logar sin muert, porque se leyén allí, así como dixiemos, e se mostravan ý todas las artes de todos los saberes, que son cosas que nunca mueren, mas siempre biven e fazen bivir al que las sabe; e el que las non sabe, o si más no algo d'ellas, tal es como muerto. E por esta razón los sabios al saber llaman vida <e> al non saber muerte ${ }^{213}$.

${ }^{209}$ GE I.2.21. Véase, Ovidio, Met. 1.150-160.

${ }^{210} G E$ I.4.9. Con nueve menciones del poeta latino.

${ }^{211} G E$ I.4.27, con dos citas del vate. Digamos que el amor de Píramo y Tisbe en Babilonia, el primero de seres humanos dentro de las Metamorfosis, está envuelto en una atmósfera oriental: Met. 4.55-166. Los enamorados vivían en moradas contiguas, y es esencial la grieta que Píramo hizo en el muro para hablar con su amada. La $G E$ recoge en latín los primeros cuatro versos (Met. 4.55-58, donde se insiste en la extraordinaria belleza del joven y en la distinción de la doncella entre todas las de Oriente).

${ }^{212} G E$ I.6.19-29, larga exposición donde contamos trece veces el nombre del poeta latino. Es un texto precioso y rico en detalles: por ejemplo el nombre de los ríos allí mencionados. Todo el relato mítico aquí expuesto puede verse con detalles en Met. 1.567-746. Algunas manifestaciones de la $G E$ nos llaman la atención. Por ejemplo éstas dos: I.6.26: «E sobre todos los otros autores Ovidio en el so Libro mayor, e esto tira a la su teología de los gentiles más que otras razones que ellos ayan. E el Ovidio Mayor non es ál entr'ellos si non la teología e la Biblia d'ello entre los gentiles». I.6.19: «Agora en este logar Ovidio, que fue muy sabio e muy cumplido poeta entre los autores (e poeta quier dezir tanto como fallador de nuevo de razón e enfeñidor d'ella e assacador), por mostrar razones de solaz por sus palabras en este fecho, e aun razones e palabras de verdad segund lo que ellos quieren dar a entender por ellas mostrar como oiredes adelant».

${ }^{213} G E$ I.7.40. No he hallado en Ovidio confirmación al aserto de este pasaje alfonsí, según el cual se habría establecido un cierto paralelismo entre Athênai, el nombre de la ciudad, y athánatos, «inmortal». Sí, en cambio en los Integumenta Ovidii de Juan de Garlandia (6.vv.279-280): Athanatos grecum sonat inmortalis, Athenas / Nominat hinc Pallas famaque vivit adhuc. 
En lo concerniente a la primera edad del mundo se indica lo siguiente: «que de las seis edades que dixiemos del tiempo que la primera tal era como oro. E esto dixo por los omnes d'essa primera edad del tiempo e del mundo porque non sabién de mal ninguno nin buscavan a otre, nin avién heredades coñoçudas nin otra cosa ninguna, nin ley nin fuero nin otro derecho ninguno si non aquel que es llamado natural». En la secuencia se recurre en cuatro ocasiones a Ovidio ${ }^{214}$. Por su parte, al referir el matrimonio de Júpiter con Juno y los hijos que tuvieron, se acude dos veces a dicho poeta ${ }^{215}$. La $G E$ revisa, asimismo, otras uniones del dios supremo: «Otrossí Júpiter en Ceres ovo a Proserpina, assí como diz Ovidio en el libro de Fastos e en ell Ovidio mayor e en otros logares, e acuerdan con él otros sabios que fablan d'esta razón $»^{216}$. Con relación a Dárdano se afirma: «Onde cuenta Ovidio en el Libro de Faustos [...] que ¿quién dubdará de Dárdano que non es fijo de Júpiter e de Electra?» ${ }^{217}$. Dentro del mismo pasaje la $G E$ alude a Atlas, «que fizo fazer un grand árvol como maçano con sus fojas e con sus frutas como maçanas todo d'oro »118. Encontramos después la lucha de Hércules contra Anteo, con las palabras del primero: «Mas dixol Hércules, segund cuenta Ovidio: 'Non assí, Anteo, non assí, mas cadrás acá e non a tierra. E allíl tovo suso fasta que se otorgó Anteo por vençudo, e estonces le dexó Hércules' $\aleph^{219}$. Tras haber relatado el diluvio de Deucalión y el incendio causado por Faetón, la GE, contraponiendo "historia»/ "poesía», se manifiesta de esta manera:

Del fecho d'este diluvio e d'esta quema vos contáramos otras razones que á ý muchas d'ellas, mas dexámoslas por esta razón, e contar vos iemos ende más razones que á ý en el fecho d'este diluvio e d'esta quema, mas dexámoslas por esta razón: los autores de los gentiles, que fueron poetas, dixieron muchas razones en que desviaron de estorias; e poetas dizen en el latín por aquello que dezimos nós en castellano enfeñidores e assacadores de nuevas razones, e fueron trobadores que trobaron en el latín, e fizieron ende sos libros en que pusieron razones estrañas e maravillosas e de solaz, mas non que acuerden con estoria menos de allegorías e de otros esponimientos; e assí fizo Ovidio, que fue poeta, en las razones d'aquel diluvio e d'aquella quema, de que dize él más que otro sabio e eñadió ý unos mudamientos d'unas cosas en otras que non son estoria por ninguna guisa. E dexámoslas aquí por ende; e esto que aquí avemos ende dicho cumpla porque aquesto es estoria ${ }^{220}$.

${ }^{214} G E$ I.7.42, donde se menciona cuatro veces al poeta latino. En Met. $1.89-150$ se nos habla de las cuatro edades: oro-plata-bronce-hierro.

${ }^{215} G E$ I.7.45.

${ }^{216} G E$ I.8.2, en un extenso pasaje, donde expone también el rapto de Prosérpina por Plutón, con muchos detalles sobre Sicilia («Cecilia» en la $G E$ ); se recurre tres veces al latino. Véanse en Ovidio, Fasti 4.587 y Met.5.341-661.

${ }^{217} G E$ I.10.31. Véase, Ovidio, Fast. 4.31.

${ }^{218}$ Ovidio, Met. 4.646-648.

${ }^{219}$ GE I.11.32, con dos alusiones al latino. Véanse en Ovidio, Met. 9.183-184; Heroidas 9.7072 , con detalles sobre el enfrentamiento. No obstante las palabras alfonsíes parecen responder a Lucano, Bellum civile 4.648-651.

${ }^{220} G E$ I.13.15. En Ovidio, Fastos 4.793-794, aparecen relacionados ambos personajes míticos. 
La historia alfonsí recurre a Ovidio en busca de autoridad para un vocablo de la traducción de Jerónimo, el crabro ${ }^{221}$, es decir, el «tábano», o «avispón»"222. También a propósito del cielo claro y limpio se cita al poeta de Sulmona ${ }^{223}$, y, asimismo, respecto a los cuatro elementos:

Onde dize Ovidio en el comienço del primero de los XV libros del su Libro mayor estos cuatro viessos por este latín: Non regio foret ulla seis animalibus orba, Astra tenent celeste solum formeque deorum, Cesserunt nitidis habitande piscibus unde, Terra feras cepit, volucres agitabilis aer.[...] E segund estas palabras de Ovidio, que fue varón tan sabio e uno de los tribunos de Roma, que era grand principado, e que dixo tantas buenas palabras e de grand saber, las creaturas del cuarto elemento, que es el fuego, que son, como oyestes, las estrellas e las formas de los dioses, animalias son ${ }^{224}$.

Con referencia al mítico Arcas, la $G E$ alude a Eusebio y Jerónimo, escuetos en el relato cronológico, y entra en Ovidio en busca de más información, citando expresamente las «mudaciones» (sc. metamorfosis) allí acontecidas ${ }^{225}$. A continuación, la obra alfonsí aborda cómo Juno, llevada por un carro celeste tirado por pavos reales, acudió ante Tetis y Océano -con un curioso e importante excurso sobre el término alumna ${ }^{226}$ - y denunció que Parrasis ${ }^{227}$ (sobrenombre de Calisto) hubiera sido convertida en estrella al mismo tiempo que su hijo (sc. Arcas); el relato se remonta hasta el nacimiento de Arcas y cuáles fueron las dos estrellas en que resultaron mudados madre e hijo, con muchos pormenores ${ }^{228}$; luego, la $G E$ se extiende en lo sucedido a Icario (el descubridor del vino), su hija Erígone y la perrilla de ésta, y cómo fueron convertidos en sendas constelaciones ${ }^{229}$. Hallamos, después, la mención de

${ }^{221}$ Cf. Éxodo 23.28.

${ }^{222}$ Véase $G E$ I.15.31, donde leemos scrabones, grafía con error o deformación, que correspondería a un supuesto e inexistente scrabo. Para crabro, -nis, cf. Ovidio, Met. 15.368-374.

${ }^{223} G E$ I.16.25. Véanse, Ovidio, Met. 1.5; 23; 85.

${ }^{224} G E$ I.20.31. El pasaje cita tres veces al poeta. Véase, Ovidio, Met. 1.72-75. El texto latino comúnmente aceptado difiere en varios elementos del alfonsí; en éste leemos, por ejemplo, seis animalibus, por suis animalibus.

${ }^{225}$ GE I.21.3, con tres alusiones al latino. A propósito de Arcas, acúdase a Ovidio, Met. 2.495-541.

${ }^{226}$ Met. 2.527. Lo dice Juno respecto a Océano-Tetis, pues, durante su niñez, habían sido sus padres adoptivos. La $G E$ lo entiende como «sobrina» y da una explicación detenida.

${ }^{227}$ Véase sobre ésta $G E$ I.21.16, respecto a un momento de tranquilidad y reposo de la citada, lapso que Júpiter aprovecharía para unirse a ella: «E Ovidio otrossí en el libro de las sanidades dell amor a que llaman Ovidio De remedio amor, e es aquí remedio por espaciamiento del mal o por sanidad que la cosa á, en que diz así sobr'esta razón este viesso en latín: Da vacue menti quo teneatur opus». La cita corresponde a Ovidio, Rem. 150, pero léase vacuae.

${ }^{228} G E$ I.21.10-13, donde se cita cinco veces al poeta; y, además, en 16-17. Para el relato de Ovidio sobre Calisto (nunca mencionada en las Metamorfosis con este nombre), acúdase a Met. 2.400-495.

${ }^{229}$ A saber, Boyero, Virgen y Can. Los hechos están recogidos en GE I.21.14-15; 18; 24-26. Respecto a Icario y Erígone, léase Met. 10.450-451. La GE, para Icario-Erígone-Canícula, sigue al «esponedor dell Ovidio» (GE I.21.14. El término «esponedor» lo tenemos en los capítulos 14 (2), 16 (2), 
Filis-Demofonte y cómo ella, abandonada, le mandó una carta, de la que se nos dan dos versos: «Hospita, Demofoon, tua te Rodepeya Pillis ultra promissum tempus abesse cueror ${ }^{230}$. E quieren estos viessos dezir en el lenguage de Castiella d'esta guisa: O tú Demofoón, yo Pilis de Ropede, la tu huéspeda, me querello de ti porque es passado el tiempo que me prometist e somos ya allend e tú non eres tornado a mí». Pasamos ahora a Dárdano, rey de Troya: «El rey Júpiter, assí como cuenta el Libro de las Generaciones de los gentiles e Ovidio en el Libro de los días faustos, ovo a Electra, fija de Atlant, rey de las Españas e de Maya, fija de Mercurio, e fizo en ella a este rey Dárdano»"231. Finalmente, en el prólogo al libro 28 de la $G E$, leemos, entre los asuntos que se iban a tratar en el mismo, esta afirmación: «E de cómo falló Ovidio en griego el romanz de las dueñas yl ovo trasladado en el latín; e entre las otras epístolas de las dueñas que fizo d'éll cómo compuso ý una por esta Ipermestra d'aquellas razones que ella embió dezir a su marido seyendo en la prisión e aún después que salió d'ella» ${ }^{232}$.

18, 24. Y, asimismo, «esplanador», en 16 y 18.). Entre los comentaristas medievales de Ovidio sobresalen, en el siglo XII, Arnulfo de Orleáns (véase nuestro apartado 2.3, sobre el calificativo que, con frecuencia, le da la $G E$, a saber, «el freire». Con esta denominación aparece doce veces en la primera parte de la $G E$ y treinta y ocho en la segunda. No obstante, el citado no perteneció a orden eclesiástica alguna, pero el equipo alfonsí pudo haberlo leído a través de alguna adaptación realizada por un fraile. Cf. Noacco 2006; Cuesta Torre 2007) y Juan de Garland o Garlandia («el inglés»), que hacia 1234 publicó los populares e influyentes Integumenta super Ovidium Metamorphoseos. Pues bien, en los pasajes recogidos al comienzo de esta nota, hay ocasiones en que la $G E$ adjudica a Ovidio afirmaciones que no están en él. Así, GE I.21.14, indica respecto a Erígone: «E los dioses, segund diz Ovidio, catando la su lealtad oviéronle merced e subiéronla al cielo, e fizieron d'ella uno de los doze signos principales del cerco Zodiaco, e aquel signo es al que dizen la Virgen; e fue esse signo aquella Herigone, segund esto»; I.21.18: «D’este Icario e de los sós cuenta Ovidio e aquel que las sus razones esplana que fue omne de Baco, a quien los gentiles llamavan su dios de los vinos»; I.21.25: «Aquella Herigone, fija de Icario, otrossí le ovieron merced sus dioses, segund cuenta Ovidio e los otros autores de los gentiles, ca dizen que la levaron e la pusieron en el cielo por uno de los doze signos principales del cerco Zodiaco»; I.21.26: «Otrossí cuenta Ovidio que los dioses que levaron al cielo el Can que aguardara a Icario allí ó yoguiera muerto». Importante en dichos pasajes son los dos comentaristas aludidos: «el inglés» (I.21.18; 26) y «el freire» (I.21.18; 26).

${ }^{230} G E$ I.22.22. Véase Ovidio, Her. 2.1-2. Encontramos varias discrepancias respecto al texto hoy común: Hospita, Demophoon, tua te Rhodopeia Phyllis/ ultra promissum tempus abesse queror. Véanse las diferencias en Demophoon, Rhodopeia Phyllis, queror.

${ }^{231} G E$ I.22.23. Acúdase a Ovidio, Fast. 4.31-32.

${ }^{232} G E$ I.28.prólogo. No he encontrado argumentos suficientes que sostengan la opinión del texto alfonsí en el sentido de que Ovidio hubiera traducido desde el griego el contenido de las Heroidas. La ovidiana Her.14 expone la carta dirigida por Hipermestra a su esposo Linceo desde la prisión donde la habia recluido su padre por haber desobedecido la orden paterna de acabar con su marido, frente a lo que hicieron sus cuarenta y nueve hermanas. Hipermestra es muy importante en la GE: cf. Impey, 1980; 2005; Almeida Cabrejas, 2013. 


\subsection{POMPEYO (12)}

En punto a lo que a nosotros nos afecta, Cneo Pompeyo Trogo ( 28 a. C.14. d. C.?), cuyo padre había sido secretario de Julio César, escribió en los años de Augusto unas Historias Filípicas (tituladas, con frecuencia, Historiae Philippicae et totius mundi origines et terrae situs), compuestas de 44 libros, así llamadas porque asuntos centrales de las mismas fueron, tanto el imperio macedónico, como su fundador, Filipo, el padre de Alejandro. La obra comenzaba con el reino asirio de Nino, Persia, Macedonia, los reinos helenísticos, Roma y sus reyes, y llegaba hasta los años del citado Augusto. El texto original se perdió, pero nos ha llegado un resumen hecho por Marco Juniano Justino, del que hablaremos: cf. apartado 3.12.

\section{bíblico José:}

3.6.1. La primera mención de Trogo la leemos en $G E$ I.8.6, a propósito del

Onde un sabio que escrivié las estorias de las cosas que acaecién en Egipto a aquella sazón, que avié nombre Pompeyo, e otro que llamavan Justino, dizién de Josep, pues que aprendieron todo su fecho, que maguer que menor era de días que sus hermanos que a todos los vencié de sotileza e de entendimiento, e porques temién d'él ellos que por esta razón quel prisieron en apartado yl vendieran a omnes estraños. E aún cuentan d'él más, e dizen que desque estos mercaderos le aduxieron a Egipto entendió muy bien Josep por ell arte mágica en que començava él ya a seer muy sabidor que aína avié a seer mucho amado del rey, cal diera Dios tamaña gracia e tamaño saber que abinié muy bien en dezir las cosas que avién a venir. E aun dizen que él fue el primero que entendió sueños e los soltó en tierra de Egipto e departió ell entendimiento d'ellos qué querién seer o qué mostravan ${ }^{234}$.

3.6.2. El segundo contexto en que aparece dicho antropónimo está en $G E$ I.13.4-7, donde, en escaso espacio, lo leemos diez veces, de las que recojo una selección:

Fallamos en estorias de los nuestros latinos que tres sabios fueron que escrivieron en arávigo mayormientre que otros a aquella sazón que esto fue las estorias de los fechos de amas las Egiptos e de todas aquellas tierras. E el mayor d'ellos e primero ovo nombre Pompeyo, e el II ${ }^{\circ}$ Cornel, el tercero Justino. Mas Pompeyo e Cornel escrivieron las estorias e Justino abrevió, esto es encortó, aquellas estorias que Pompeyo e Cornel escrivieron, peró las de Pompeyo, mas non las de Cornel. E en cabo todas fincaron escritas las unas e las otras. D'éstos retrae sobr'esta razón Paulo Orosio en el $\mathrm{IX}^{\circ}$ capítulo del su primero libro de las Estorias de los gentiles ${ }^{235}$ que dixieron

${ }^{233}$ Sobre la presencia de Pompeyo Trogo y su compilador Justino en la GE, cf. Eisenberg, 1973; Saquero Suárez-Somonte - González Rolán, 1993.

${ }^{234}$ Cf. Justino, 36.2, donde se recogen esos datos y bastantes más.

${ }^{235}$ Orosio, Historiae adversus paganos 1.10. Podemos afirmar que el juicio de la $G E$ tanto sobre Pompeyo Trogo como acerca de Justino está tomado de la citada obra de Orosio. Nos llama 
aquel Pompeyo e Cornel cómo vinieran sobre Egipto aquellas plagas que avemos dichas tan grandes e tan desmesuradas de mal que non era yente en el mundo que sofrir las pudiesse ${ }^{236}$.

3.6.3. Precisamente en la citada secuencia leemos la última alusión ofrecida en la $G E$ (I.13.7), respecto del hombre al que Moisés dio muerte, y, asimismo, de cómo el faraón murió en el mar durante la persecución de los hebreos. Tras recoger el relato dado por ciertas fuentes árabes, el texto alfonsí nos indica: «E esto assí lo razonan aquellos arávigos, e d'esta guisa fablaron de Moisén e de los otros ebreos sobre la salida de Egipto estos arávigos e caldeos, e tenemos que éstos se acogieron más e mejor a la verdad que Pompeyo e Justino nin Cornel».

\subsection{MuCiano (1)}

Gayo Licinio Muciano, tres veces cónsul (la última en el 72 d. C.), tuvo altos cargos con Vespasiano a cuyo lado estuvo en Judea, antes de la guerra judaica. En el campo que nos interesa fue autor de escritos geográficos y se interesó por los asuntos maravillosos ${ }^{237}$. Plinio lo cita en 52 ocasiones. Ya lo hemos mencionado en el apartado 2.1.2.

\subsection{Plinio $(138)^{238}$}

3.8.1. Plinio el Viejo (Gaius Plinius Secundus) vivió entre los años 23-79 d. C. Su presencia es muy importante en la $G E$, donde, con frecuencia, se dice el libro y capítulo de la obra: la "Natural Estoria»" ${ }^{239}$. En la parte estudiada lo hemos localizado

la atención que la $G E$ considere autores arábigos tanto a Pompeyo como a Tácito, si el equipo tenía a mano el texto latino de Orosio, de donde podía deducirse fácilmente que ambos escritores eran romanos y que sus obras respectivas estaban en latín. En lo concerniente a Justino, véase el apartado 3.12. ${ }^{236}$ Acúdase a Justino, 36.2. La GE, en el citado lugar, sigue hablando de Pompeyo y Justino, ajustándose bastante al texto de Orosio (véanse apartados 3.15.4, 3.15.5).

${ }^{237}$ Véase Caldwell, 2015.

${ }^{238}$ Por número de citas ocupa el tercer puesto dentro de la $1^{\text {a }}$ parte de la GE. Para su presencia e influencia en España, véanse Rico, 1972: 127, 177; Eisenberg, 1973; Casas Rigall, 1999: 165, 233; y, especialmente, Moure Casas, 2008.

${ }^{239}$ Cf. GE I.7.7: «Sobr'este departimiento cuenta Plinio en el dozeno capítulo del quinto libro de la Natural estoria»; I.10.22: "Cuenta Plinio en el segundo capítulo del quinto libro de la Natural estoria ó fabla de las tierras e de las estrañezas d'ellas»; I.11.9: «E era este Apis un toro, e d'este toro vos diremos luego lo que dize Plinio por éll en el ochavo libro de la Natural estoria en el capítulo XLVI"»; I.11.39: «E contar vos emos aquí las fechuras e las costumbres d'estas yentes segund las dize el Plinio en su libro de la Estoria natural»; etc. Hallamos alguna variante sintáctica: I.15.85 «segund vos contaremos adelant assí como lo fallamos en la natural estoria que compuso Plinio». Sobre una obra perdida del autor, véase Virgilio, nota 202. 
en 138 contextos. Ya hemos encontrado bastantes referencias (véanse, por ejemplo, nuestros apartados 2.1.1, 2.1.2, 2.6, 2.9, 2.11, 2.14, 2.26, 2.31.2, 2.32.4).

3.8.2. Recogeré ahora los más relevantes de entre los pasajes no nombrados todavía, siguiendo el curso de la historia que estudiamos. Así, en punto al tamaño de Asia: «Asia, segund dize Plinio, e Paulo Orosio, e el Libro de las provincias, e maestre Galter en el Alexandre, tiene tamaño término como las otras dos, que son Europa e África, e aun algunos dizen que es mayor, e comiénçase en orient, e de como cata a occident tiene del su diestro fasta septentrión, e de siniestro fasta mediodía, e de todas las partes de fuera aderredor enciérrala ell Oceano ${ }^{240}$. Se trata de una secuencia amplia donde se cita tres veces al naturalista romano y se habla de los montes Rifeos, la laguna Meótida, el mar Euxino, la fuente Nigris, el Nilo, etc. Relevante para la $G E$ es la fuente Nigris: «por los manantiales o manaderos de la fuent Nigris de que fabló Plinio e otros muchos dond lo tomó él» $»^{211}$ y, otra vez: «Parten a Asia de África por medio de la tierra como va de aquella parte en derecho de somo de Europa a mediodía los manaderos de la fuent Nigris, que es el comienço del río de Egipto a que dizen Nilo, segund departe Plinio e Lucano e otros muchos sabios que fablan d'él ${ }^{242}$. Se menciona al naturalista a propósito de que sólo el hombre precisa de vestidos, no los demás animales ${ }^{243}$. También lo vemos en afirmaciones alusivas a imágenes e ídolos ${ }^{244}$, y, asimismo, respecto a Europa: «cómo era la mejor e la más temprada tierra del mundo, e la más abondada de muchas buenas cosas, ca tal es Europa, e entre muchas buenas tierras que a en ella la provincia de Guadalquevir es la mejor, e aun de cuantas otras en el mundo son, assí como dize Plinio en el tercero libro ó departe d'estas tres tierras, Europa, Asia e África, e de las provincias d'ellas ${ }^{245}$. Se recurre al citado prosista para tener noticias sobre las personas de enorme estatura ${ }^{246}, y$, también, en lo concerniente al ave Fénix y dónde vive ${ }^{247}$. Se le cita, de nuevo, a propósito de los manantiales del Nilo: «Peró los tres d'ellos muy mayores que los otros, segund cuenta el Plinio, e diz que an estos nombres que aquí seen: Astapo, Astobores e Astusapes $»^{248}$. Se le consulta

\footnotetext{
${ }^{240} G E$ I.2.23. Léanse en Plinio, $H N 3.3 .1,6.33,6.209-210$, etc.

${ }^{241} G E$ I.3.4. Nótese la referencia a las fuentes en que se basaría Plinio. Sobre dicha fuente véanse notas 14 y 100 .

${ }^{242} G E$ I.2.33. En Lucano son frecuentes las alusiones al Nilo, pero no he encontrado ninguna a la fuente Nigris.

${ }^{243} G E$ I.3.11. Acúdase a Plinio, $H N 7.2$.

${ }^{244} G E$ I.3.17. Consúltese Plinio, $H N$ 2.6-7.

${ }^{245}$ GE I.3.21. Véase Plinio, HN3.3-5, sobre Europa, allí elogiada. En cambio en 3.6, dedicado a Hispania, hace una descripción geográfica, pero no dice nada elogioso de ninguna de sus partes. ${ }^{246} G E$ I.3.23.Cf. $H N 7.73-75$.

${ }^{247} G E$ I.4.2: «e sobre Caldea más arriba a parte de oriente tierra de Aravia, ó son los árvoles en que nacen las muchas especias e de muy buenas oluras e de grandes virtudes, e ó dize Plinio e otros filósofos e naturales que mora ell ave Fénix, que vive d'aquellas especias e non de ál». $H N 10.3 .1 ; 10.5 .1$; 12.85.1; 13.42.6; 29.29.1.

${ }^{248} G E$ I.5.14. Consúltese, $H N 5.53$.
} 
sobre Júpiter como planeta ${ }^{249}$, y en lo relativo al Bósforo ${ }^{250}$, la magnitud de Egipto y cómo la divide el Nilo ${ }^{251}$; asimismo, en punto a otros elementos de indudable interés, como el cocodrilo («cocadriz», en Alfonso), mangosta y delfines del Nilo y otros animales ${ }^{252}$, el monte Atlas y ciertos hechos que allí suceden ${ }^{253}$, el río Anat ${ }^{254}$, numerosos datos sobre el Atlas ${ }^{255}$, el toro Apis de Egipto ${ }^{256}$ y el Nilo como frontera entre Egipto y Etiopía ${ }^{257}$. Además, a propósito del ibis y cómo se purga a sí mismo ${ }^{258}$, el Nigris y las gentes que vivían junto a él'259 («los atlantas, los egipcianos, los semferos, los plemios, los grantafantes, los sátiros, los imantopades»). Remontan al naturalista no pocos detalles sobre los atlantes, trogoditas, garamantes, ganfasantes, blemnios, sátiros, himantópodes y farusos ${ }^{260}$, y de no poca relevancia es la mención de otros elementos de Egipto, coronada con una frase latina (Asia adheret), en la que se ha cambiado el orden de palabras del original ${ }^{261}$. Otras referencias a Plinio las hallamos en punto a la mirra: «e leemos que á ý tres maneras de mirra, o aun cuatro, segund vos contaremos adelant assí como lo fallamos en la natural estoria que compuso Plinio» ${ }^{262}$; y, también, la púrpura («pórpola», en $G E)^{263}$. Es más, en el mundo animal, proceden del romano las indicaciones a propósito de la menstruación ${ }^{264}$, la unión de leoparda y león, o de leona y leopardo, la condición sexual del león y cómo advierte si la leona ha estado con un leopardo, el león que se amansó ante las palabras de una cautiva, y quién fue

${ }^{249} G E$ 1.6.21. En $H N 2.35$.

${ }^{250} G E$ I.6.28. En la obra alfonsí leemos: «E es Bosforo cosa de que fabla el Plinio e otros muchos sabios». Cf. $H N$ 4.76.9, donde distingue dos, el cimerio y el tracio. Nombra el término Bosporus en 32 secuencias.

${ }^{251} G E$ I.7.7, con dos menciones. Cf. HN 5.48.

${ }^{252} G E$ I.8.14-15, con cinco menciones del naturalista. Cf. $H N$ 8.89-93.

${ }^{253} G E$ I.10.21-23, donde se nombra seis veces al autor romano. Véase HN 5.5.10-16.

${ }^{254} G E$ I.10.25. Dicho río ya lo hemos visto en el apartado 2.17.

${ }^{255} G E$ I.10.16-17.Cuatro menciones del prosista romano.

${ }^{256} G E$ I. 11.9-12. Siete menciones del naturalista. Cf. HN8.184-186. La $G E$ recurre, además, a otras fuentes.

${ }^{257} G E$ I.11.36. Consúltese $H N 5.48$.

${ }^{258} G E$ I.11.38. En este mismo capítulo leemos: «En Egipto á una manera de cigoñas a que llaman ybes o ybices, e son otrossí tantas d'aquellas cigüeñas en aquella tierra que lo non podrié omne contar, e quieren mal a aquellas serpientes, e an por natura de matar cuantas alcançan d'ellas, e las serpientes otrossí an natura de temerlas más que a otra cosa que en el mundo sea e fuir d'ellas cuanto pueden e asconderse». Cf. $H N$ 8.97.

${ }^{259} G E$ I.11.39, con tres alusiones sobre el naturalista. Se mencionan también los garamantes y trogoditas, entre otros pueblos. HN 5.43-45, donde hay comparar con cuidado la grafía del romano con lo ofrecido por la $G E$.

${ }^{260} G E$ I.11.40, con dos alusiones al prosista. Véase HN 5.45-46.

${ }^{261} G E$ I.13.35, y dos menciones del escritor romano. Consúltese HN 5.47: Adhaeret Asia.

${ }^{262} G E$ I.15.85. Cf. $H N 24.159 ; 26.108$.

${ }^{263} G E$ I.16.25. Véase $H N 9.125-127$.

${ }^{264} G E$ I.19.11. Léase $H N 9.125-127$. 
el primero que amansó al león ${ }^{265}$. De Plinio se toman las noticias referentes a la naturaleza de los tigres ${ }^{266} \mathrm{y}$ del lobo, así como relatos en torno a los llamados hombres-lobo, donde encontramos una curiosa etimología del término griego lýkos ('lobo'), los perros que conviven con el hombre y algunas historias sobre su fidelidad, la unión del perro con la tigresa y la loba, la nobleza y valentía de los perros de Albania, cuándo queda preñada la perra y la rabia de los perros. También datos diversos respecto a las medicinas contra la mordedura del perro rabioso ${ }^{267}$, el caballo y su inteligencia, cómo los altos príncipes enterraban al suyo, anécdotas sobre Bucéfalo, el caballo de Alejandro, y de otros famosos rocines, cuánto vive el caballo y cuándo queda preñada la yegua, el parto de la misma y la crianza del potrillo, la naturaleza del asno, la unión de éste con yegua y de caballo con asna ${ }^{268}$. Asimismo, a propósito de la naturaleza de la oveja y el carnero, la lana y sus colores, la naturaleza de las cabras, la mezcla de carnero y cabra y de oveja y macho cabrío, los animales de los tres elementos (agua, tierra y aire), las uniones entre los pescados, las uniones entre aves y animales terrestres y de las aves entre sí, la naturaleza de las mezclas en las cosas, y, finalmente, los tres poderes del alma ${ }^{269}$.

\subsection{LUCANO (7) 270}

Su corta vida transcurrió entre los años 39-65 d. C. Autor épico, su obra se tituló Bellum civile (y también Pharsalia), en la que se narra la guerra civil entre César y Pompeyo. De sus apariciones en la $G E$ hemos citado ya algunas, respectivamente en apartados 2.1.2 y 3.8.2. Veamos las que todavía nos quedan por exponer: «E dize otrossí Lucano en la estoria de Pompeyo el Grand e de Julio César ${ }^{271}$ que Arax es allí nombre d'un río, e lieva la tierra nombre d'él, como Iberia, que es por España, del su río Ebro» ${ }^{272}$. Tenemos, luego, un pasaje largo en donde se habla del sacerdote Acoreo $^{273}$, ya mencionado, dentro de una secuencia importante con tres menciones del escritor épico:

${ }^{265}$ GE I.20.9. Con cuatro menciones del escritor (en 1.20.9-35 contamos 82 alusiones del naturalista. Algunas ya las hemos visto). Consúltese $H N$ 8.41-58.

${ }^{266} G E$ I.20.13. Acúdase a $H N 8.66$.

${ }^{267} G E$ I.20.14-19, con doce menciones del naturalista. Véase $H N 8.72-76,80-84,142-153$.

${ }^{268} G E$ I.20.20-26. Con 19 citas del prosista romano. Cf. $H N$ 8.154-175.

${ }^{269} G E$ I.20.27-35. Es una larga secuencia donde hallamos 30 menciones del escritor romano. Cf., especialmente, $H N 8.187-209$; 9.158-164; 10.1-2. En tal referencia de la $G E$ se alude a varios lugares de la $H N$ : concretamente, a los libros 9 (Peces), 10 (Aves), 18 (Cereales).

${ }^{270}$ Acerca de la presencia de Lucano en Alfonso X, véanse Rubio Álvarez, 1958; Herrero Llorente, 1957, 1959; Lida de Malkiel, 1959-1960; Almazán, 1963; Eisenberg, 1973.

${ }^{271} \mathrm{La} G E$, en la primera parte, llama aquí a la obra de Lucano «la estoria de Pompeyo el Grand e de Julio César», y, asimismo, como veremos más abajo, «el libro de las batallas de los cibdadanos de Roma».

${ }^{272} G E$ I.2.25. «Arax» es el Araxes, río de Armenia, citado por Lucano en BC 7.188, 8.431.

${ }^{273}$ Ya visto en apartado 2.7. 
E pues que sobr'el fecho del Nilo avemos movido razón queremos dezir en este logar cuanto ende fallamos, e contaremos lo que diz dend Lucano por sí e por el obispo Acoreo.

IX De la razón de Lucano sobr'el Nilo.

Cuenta Lucano en el dezeno libro de las batallas de los cibdadanos de Roma que pues que Pompeyo el Grand e Julio César, que fueron los grandes e muy nobles romanos, lidiaron, e fue vencido Pompeyo $[\ldots]^{274}$.

Por último, leemos así: «E aquí torna Lucano de Córdova de España a razónarse contra'l obispo Acoreo <e> de cabo con Julio César en esta razón, e diz así»» ${ }^{275}$.

\subsection{ESTACIO (2)}

Su vida suele fecharse entre los años 45-96 d. $\mathrm{C}^{276}$. Lo hemos visto ya en el apartado 2.6, a propósito del monte Atlas. En la $G E$, dentro del texto revisado, no se mencionan ni las obras poéticas de dicho poeta ni los títulos de las mismas. Pero, por las referencias que hemos podido comprobar hasta aquí, hay alusiones a la Tebaida y las Silvas. Nos queda otra cita del mismo, donde la $G E$ nos dice a propósito de los faraones: «E otrossí porque avemos dicho en esta estoria muchas vezes de los faraones tebeos e non departimos aún en ningún logar donde ovieron este nombre queremos aquí departir dond le levaron, e fazer lo emos por razón de algunos que cuedan que fueron estos tebeos de la cibdad de Tebas la que pobló Cadmo, fijo del rey Agenor, assí como dizen Ovidio e Estacio e otros» ${ }^{277}$.

\subsection{TÁcito (16: Cornel, 13; Cornel Tácito, 1; Cornelio, 1; Corneyo, 1) ${ }^{278}$}

Publio Cornelio Tácito vivió en los años 55-120. De sus cinco obras conservadas nos interesan aquí sus Historias. En $G E$ I.13.4-7 encontramos varias maneras de nombrar al autor ${ }^{279}$. Ya lo hemos visto en los apartados 3.6.2 (1), 3.6.3 (5).

${ }^{274}$ GE I.5.8-9. Siguen muchos detalles sobre la relación de Pompeyo con Ptolomeo Filopátor y de César con Cleopatra "mancebiella e grand e muy fermosa", así como el enamoramiento mutuo de los dos últimos y la boda fastuosa, donde Acoreo ocupó un sitio de honor. Precisamente, el capítulo 10 contiene las razones que César expuso ante Acoreo a propósito del Nilo.

${ }^{275} G E$ I.5.16. A continuación, el capítulo 17 está dedicado a las palabras de César.

${ }^{276}$ Para su presencia en la GE, véase Rico, 1972: 41, 175, 187; Eisenberg, 1973; Saquero SuárezSomonte, 2002.

${ }^{277}$ GE I.7.7. Sobre Cadmo, cf. Ovidio, Met.3.3, 3.14, 3.24, 3.115, y así hasta 18 menciones en el conjunto de sus obras; y, además, Estacio, Tebaida 1.6, 1.15, 1.223, etc, con un total de 34 lugares en sus obras.

${ }^{278}$ Por número de citas ocupa el décimo puesto dentro de la 1a parte de la GE. Para su presencia en la GE, véanse Eisenberg, 1973; Codoñer, 1990; Saquero Suárez-Somonte-González Rolán, 1993.

${ }^{279}$ Véanse apartados 3.6.2 (1), 3.6.3 (5). En la Primera parte de la GE, como "Cornel Tácito", lo tenemos una sola vez. El resto figura como Cornelio (1), Cornel (13), Corneyo (1). En el Índice 
Acudo ahora a otras menciones. La primera en $G E$ I.5.31, en torno a la destrucción de Sodoma y Gomorra, más otras tres ciudades vecinas, y cómo todo, por castigo divino, quedó convertido en un lago: «D’este lago cuentan muchas cosas, e diz Cornelio que el agua d'él es empoçoñada, e que el baho que sale d'ella corrompe la tierra de aderredor de sí e fázela mañera» ${ }^{280}$. A continuación, algo después (GEI.5.32), leemos dos citas:

Onde por testiguar esto e firmarlo cuenta otrossí sobr'ello Cornel Tácito que non alueñe de Aravia los campos que ý avié muy plantíos e poblados de grandes poderes de omnes ardieron a rayos que cayeron del cielo e encendieron toda la tierra, e más dize aún otrossí allí Cornel, que la tierra fincó en su semejança de dura e fuerte como era antes, mas que perdió la fuerça de levar frutos, e dize adelante que fue fuego del cielo aquel que quemó aquellas cibdades, e que, segunt asma, que el bafo d'aquel fuego que ensuzió e empoçoñó las aguas e la tierra d'allí de guisa que les tollió la fuerça de criar ninguna $\operatorname{cosa}^{281}$.

Por último, para $G E$ I.19.6, véase Justino.

\subsection{JUSTINO (8)}

3.12.1. Marco Juniano Justino Frontino floreció en la segunda mitad del III d. C. En el último decenio de esa centuria hizo un resumen, con no pocas ampliaciones, de la obra de Pompeyo Trogo, ya mencionada. Sus digresiones son muchas y, con frecuencia, con propósito moralizador. Fue autor muy leído durante el Medievo.

3.12.2. Lo hemos visto ya en los apartados 3.6.1, 3.6.2 y 3.6.3. Nos queda un pasaje de $G E$ I.19.6, donde, a propósito del leproso y la lepra ("gafo», "gafez») y de las recomendaciones de la Biblia, leemos: «Onde vos contaremos agora aquí sobr' esto unas razones que cuenta Josefo contra Corneyo e contra Justino, que escrivieran esta estoria en ell egipciano, e contra otros arávigos que lo escrivieron en ell arávigo; e dezir vos emos aquí esto sobre unas razones que vos contamos ya en la estoria del libro Éxodo e las non dixiemos ý todas $»^{282}$. El texto alfonsí se extiende,

parece entenderse que Cornel-Corneyo son distintos de Cornel Tácito. No he recogido todas las menciones del escritor: muchas de ellas se encuentran en GE I.13.4 (5), I.13.5 (6), I.13.7 (1).

${ }^{280}$ Véase Orosio, Historiae adversus paganos 1.5, donde éste cita al historiador romano (Cornelius Tacitus), concretamente sus Hist. 5.7.1 (Haud procul[... Jreor. Con alguna omisión); también lo menciona en el cap. 10: Pompeius Corneliusque, más otras dos veces (Cornelius) y da otra referencia de las Hist. 5.3 (plurimi auctores[...]pepulissent), a la que sigue la interpretación del propio Orosio.

${ }^{281}$ De nuevo, consúltense los mismos lugares de Orosio y Tácito ya indicados.

${ }^{282}$ Puede acudirse a Justino, 36.2.12: Sed Aegyptii, cum scabiem et uitiliginem paterentur, responso moniti eum cum aegris, ne pestis ad plures serperet, terminis Aegypti pellunt. Dux igitur exulum factus sacra Aegyptiorum furto abstulit, quae repetentes armis Aegyptii domum redire tempestatibus conpulsi sunt. Osorio, 1.10, recoge ese texto, y lo refiere a Pompeyo Trogo o a Justino: Ait enim Pompeius, siue Iustinus, hoc modo. 
a continuación, en un comentario sobre el criterio de Josefo en punto a la lepra. Lo que nos llama la atención es que se insista aquí en que Cornelio (aquí «Corneyo») y Justino hubieran escrito en árabe su relato, como ya lo vimos en el apartado 3.6.2.

\subsection{JERÓNIMO $(364)^{283}$}

3.13.1. El escritor suele fecharse entre los años 340-420 d. C. Autor de numerosas obras, me limitaré a dos títulos auténticos ${ }^{284} q u e$ aparecen aludidos en esta aportación: el Cronicón (en latín Chronicon, adaptación del griego, Chronikón²85, ya apuntado

${ }^{283}$ Por número de citas ocupa el segundo puesto dentro de la $1^{\text {a }}$ parte de la GE. Para la presencia e influencia de Jerónimo en Alfonso X, véanse, entre muchos, Rico, 1972: 22, 31, 51...; Eisenberg, 1973; Perona, 1998; Fernández Ordóñez, 1999: 119-120; etc.

${ }^{284}$ Véase además el siguiente pasaje ( $G E$ I.13.8): «las plagas que Nuestro Señor Dios envió sobre Egipto muchas más fueron que aquellas que vos avemos dicho que cuentan Moisén e Jerónimo en el libro del Martirojo que los santos padres e los otros varones buenos que fueron en componer e fazer el libro Cómpoto e aquel tractado del Martirojo yl fizieron». Se menciona, pues, el conocido como Martyriologium Hieronymianum, considerado el martirologio más antiguo, escrito en Italia durante la segunda mitad del siglo v y que fue atribuido erróneamente a Jerónimo. Cf. Martyrologium Hieronymianum, G. B. de Rossi - L. Duchesne (eds.), en Acta Sanctorum LXXXII, II, Bruselas, Société des Bollandistes, 1894.

${ }^{285}$ Con respecto al contenido de dicha obra, encontramos distribuciones de varios tipos. Selecciono algunas de ellas: 1. A veces es citada con algún nombre alusivo a ese título: $G E$ I.4.1: «assí como dizen Eusebio e Jerónimo en la primera parte de la su Crónica de los años e lo avemos nós ya dicho»; I.6.18: «E pues que Eusebio, que fue obispo de Cesarea e santo omne, e Jerónimo, otrossí obispo e santo, e que trasladó la Biblia en este nuestro latín, fablan d'estas razones en sus crónicas»; I.9.13: «Andados catorze años del poderío de Josep cuentan sobr'este logar Eusebio e Jerónimo en sus crónicas que en el sexto año d'aquellos siete malos murió aquel Faraón Nicrao del que avemos contado fasta aquí»; I.10.5: «segund cuentan las crónicas de Eusebio en el griego e de Jerónimo en el latín»; I.10.13: «assí como cuentan Eusebio e Jerónimo e todas las otras crónicas e estorias e lo avemos nós ya departido muchas vezes»; I.10.36: «E assí como cuentan las crónicas de Eusebio e de Jerónimo, aquellos cuatro reyes faraones que regnaron en Egipto en aquel tiempo que dezimos»; I.11.34: «E a este Triopa llaman Santo Eusebio e Jerónimo en sus crónicas, e por ventura aviélo por sobrenombre»; 2. En otras ocasiones, está apuntada mediante alguna perífrasis: I.3.31: «assí como diz Jerónimo en el traslado de Eusebio»; I.4.29: «segund la cuenta de Eusebio en el griego e de Jerónimo en el latín»; I.5.2: «assí como dize Eusebio en el griego e Jerónimo en latín en el traslado que fizo d'aquella razón de Eusebio»; I.6.18: «En esta sazón, assí como cuenta Eusebio en el griego e Jerónimo en el latín[...]»; I.6.28: «e esto es lo que ende cuentan Eusebio en el griego e Jerónimo en el latín, en que dizen assí: Ínaco, el río de la cibdad de Argos de Grecia es llamado Bosfor de Ío su fija del rey»; I.11.34: «Onde dizen el obispo Eusebio en el griego e Jerónimo por esse Eusebio en el latín»; I.12.5: «segund las cuentas de Eusebio e de Jerónimo e de otros»; 3. Pero no faltan pasajes en que se cita sólo a Jerónimo, y, en esos casos, el lector debe deducir que se trata del tratado cronológico, y no de la Biblia. Por ejemplo: I.3.23: "Andados de Noé ochocientos e cincuaenta e cinco años, e de Sem trezientos e cincuaenta e cinco, e del diluvio dozientos e cincuaenta e tres, segund Jerónimo, murió Nemprot, rey de Babiloña, e regnó empós él aquel su fijo Belo. E fueron Nemprot el primero rey de Babiloña e Belo el segundo». 


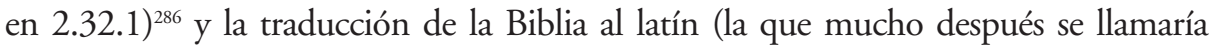
Vulgata $)^{287}$. Hemos citado ya al escritor en varias ocasiones: cf. apartados 2.20.2, 2.20.3, 2.20.4, 2.29.2, 2.29.3.1, 2.29.3.6, 2.31.1, 2.31.2, 2.32.1, 2.32.3, 2.32.4.

3.13.2. Dado el elevado número de menciones, he creído que podría resultar útil para futuros estudiosos distribuirlas, sin ánimo de exhaustividad, de acuerdo con algunas peculiaridades explicadas en los apartados correspondientes.

3.13.2.1. Cita sólo junto a Moisés: I.1.3; I.6.11; I.8.12; I.9.15; I.11.2; I.12.prólogo; I.13.7; I.13.8; I.14.18; I.15.1; I.15.79; I.15.82; I.15.84 (2); I.16.2; I.16.8; I.16.11; I.16.17 (2); I.16.18; I.17.3 (2); I.17.11; I.17.17 (2); I.17.21; I.17.22; I.17.23; I.17.24; I.17.25; I.17.26; I.17.27; I.17.28; I.17.33; I.17.36; I.18.6; I.18.8; I.19.prólogo: «En este libro fablan en la Biblia Moisén en el ebraigo e Jerónimo en el latín, e muchos otros sabios e santos padres que acuerdan con ellos en sus estorias e esponimientos que fizieron sobr'esto» (cito otros ejemplos de «hebreo»" ${ }^{288}$ ); I.19.1; I.19.4; I.19.5 (2); I.19.6; I.19.7; I.19.8; I.19.13; I.19.20 (2); I.20.prólogo; I.20.4; I.20.6 (3); I.20.34; I.20.36; I.20.41; I.20.44; I.20.53; I.21.1; I.21.2; I.22.prólogo; I.22.3; I.22.4; I.22.8; I.22.17; I.23.3 (2); I.23.7; I.23.29; І.24.3; I.24.6; I.24.7; I.24.15; I.24.16; I.24.17; I.24.18; I.24.19; I.24.22; I.24.23; I.25.3 (3); I.25.8; I.25.9; I.25.10; I.25.36 (2); I.25.37; I.25.38; I.25.42; I.26.8; I.27.5; I.29.21: «segund dizen en la Biblia Moisén en el ebraico e Jerónimo en el latín en el postrimero capítulo del Deuteronomio».

3.13.2.2. Aparece Jerónimo solo (no me detengo en frases copulativas cuando consta junto a los nombres de otros autores, pero sí lo anoto cuando está acompañado de la expresión «los otros», sin especificar antropónimo alguno): I.1.26; I.1.30: «E qui más ý quisiere búsquelo segund Jerónimo faze la cuenta, e fallar lo á»; I.2.2; I.2.5; I.3.23; I.3.24; I.4.17; I.5.18; I.5.33 (3); I.6.9; I.6.10; I.6.11; I.6.16 (4); I.7.20; I.7.22 (3);

${ }^{286}$ Además de lo indicado al hablar de Eusebio añadiremos algunas consideraciones. Habiendo partido de la obra de éste, Jerónimo amplió los datos hasta el 379 d. C.: es decir, comienza en Abrahán y termina en hechos de su propia época. Las tablas cronológicas resultaron esenciales para el estudio de la historia universal, y, además, sus aportaciones fueron el punto de partida para crónicas posteriores.

${ }^{287}$ El Papa Dámaso le recomendó a Jerónimo que revisara la traducción latina de la Biblia (la Vetus Latina), pero éste se decidió a hacerla de nuevo (así, en 382, entregó el Nuevo Testamento; en 405, acabó la versión del Antiguo). Los estudiosos indican que, aunque conocía la versión griega de los Setenta, entonces canónica en la Iglesia, prefirió partir del texto hebreo tradicional.

${ }^{288}$ I.10.42: «assí como lo cuenta Moisén en el ebraigo, e Jerónimo en el latín»; I.11.26: «E esta fue la una razón por que dizié ell ebraigo que fue Moisén embargado de la lengua». Hay otros apariciones de "en ebraigo", pero conectadas directamente con Moisés, por lo que el giro pudiera referirse al texto seguido o a la lengua, sin más. En otros casos alude a la versión en hebreo de la Biblia. Así en I.17.prólogo: «Tres nombres fallamos que á este libro Levítico, ell uno en griego, ell otro en latín, ell otro en el ebraigo». 
I.9.39; I.12.1; I.14.23; I.15.63: «La estoria del nuestro traslado de Jerónimo en la Biblia dize assí en el XXVIII capítulo»; y, en el mismo capítulo: «e el nuestro traslado de Jerónimo en la Biblia non dize d'esta razón más d'esto»; I.15.75: «E Jerónimo en el traslado de la Biblia en el XXVIII ${ }^{\circ}$ capítulo dell Éxodo llamal tiara»; I.15.78 (2); I.15.79; I.15.83; I.15.84; I.16.3; I.16.16; I.17.prólogo; I.17.13; I.17.15; I.17.20; I.20.41; I.20.53; I.20.56; I.20.60; I.21.prólogo (4):

Sobresto diz Jerónimo en la glosa del primero capítulo del libro Número en la cuenta d'estas posadas de los fijos de Israel que de la primera posada fasta la postrimera fueron cuarenta e dos. E departe sobr'esto que por estas XLII posadas que diz Mateo evangelista en su evangelio que de Abraham fasta David ovo XIIII generaciones, e de David fasta la trasmigración de Babiloña otras XIIII, e de la trasmigración de Babiloña fasta Cristo otras XIIII, e tres catorzenas son cuarenta e dos. E diz Jerónimo en esta glosa otrossí que el judío que dexando ell Egipto del sieglo, esto es su talent, quisiesse entrar en tierra de promissión, e de la tierra de promissión sobir al cielo, e lo que los nombres d'estas posadas dan a entender, segund las Enterpretaciones de Ramiro, que son esponimientos d'aquellos nombres, adelant vos lo departiremos en sos capítulos apartados. E diz otrossí Jerónimo allí en el cabo d'aquella glosa que non es maravilla si por el sagramiento d'esta cuenta, que es santa, viene ell omne bueno al cielo, pues que Cristo quiso venir por él e vino del primero patriarca a la Virgen como vino otrossí el pueblo de Israel al río Jordán, que corriendo como río lleno abondó de la gracia dell espíritu santo de Dios. Pues que vos esto avemos dicho del prólogo e de los esponimientos de los santos padres tornaremos agora a contarvos d'aquello que diz la letra de la Biblia, e Josefo e Jerónimo e Teodocio e los otros trasladadores e otrossí los santos padres que esplanaron lo que éstos dixieron.

[Nótese cómo se consulta el Nuevo Testamento para interpretar algún pasaje del Viejo]; I.21.1: «E estos príncipes mayorales de los doze linages cuentan aquí Jerónimo e los esponedores de la Biblia»; I.21.19; I.21.20 (2); I.22.6 (2); I.22.7 (2. En el $2^{\circ}$ caso leemos: «fabla Jerónimo en la glosa sobr'este noveno capítulo del Número»); I.22.8; I.22.9; I.22.10; I.22.12 (2); I.22.19 (2); I.22.20; I.23.4; I.23.6 (2); I.23.8: «Onde dixo assí adelant otrossí Moisén, segund cuenta Jerónimo en el XVI ${ }^{\circ}$ capítulo del Número» [una variatio por Moisés y Jerónimo]; I.23.13 (2); I.23.14; I.23.15; I.23.21; I.23.24; I.24.9; I.24.11; I.24.12; I.24.13; I.24.21; I.24.22; I.25.3; I.25.5; I.25.6; I.25.10; I.25.12; I.25.21; I.25.32; I.25.33 (2); I.25.34; I.25.35 (2); I.25.36; I.25.39; I.26.prólogo; I.26.1; I.26.9; I.26.11; I.26.17; I.26.19; I.26.21; I.26.22; I.26.24; I.26.26; I.26.27; I.27.6; I.27.8; I.28.1; I.28.5; I.28.8.

3.13.2.3. Jerónimo «en la glosa» ${ }^{289}$, sin ningún otro autor: I.1.25; I.1.26; I.1.30; I.2.1 (2); I.2.25; I.4.5; I.4.15; I.5.2; I.6.8 (2); I.7.18; I.13.30; I.14.33; I.14.35.

${ }^{289}$ Desde el siglo XII se denomina «la Glosa» a las exegesis medievales que enriquecieron el texto latino de la Biblia parisina. Cf. Rubio Tovar, 2014: 261. La editio princeps de la Biblia latina cum glossa 
3.13.2.4. Una selección de ejemplos en que aparece bien al lado de sólo otra fuente (la Biblia y Jerónimo: I.16.4; Isidro ${ }^{290}$ y Jerónimo: I.3.3; con Agustín: I.2.7; con «maestre Pedro»: I.6.4; I.6.6; I.6.9; I.7.18), bien al lado de otras dos (con Moisés y Agustín, I.15.83; con los Setenta y Agustín: I.15.31; con Beda y Agustín: I.2.13; con Agustín y Gregorio: I.14.35).

3.13.2.5. En ocasiones se dice Moisés-Jerónimo, cuando la cita o comprobación procede de Eusebio-Jerónimo (la Crónica): I.6.11:

Visco Sarra C e XXVII, assí como dize Moisén en el XX III capítulo del Génesis, e murió en val de Mambre andados de Adam, segund cuenta Moisén e Jerónimo, dos mill e cuatrocientos e XXVII años, e de Noé mill e cuarenta e I, e del diluvio quinientos e cuarenta e uno, e del departimiento de las lenguas cuatrocientos e XLI, e del regnado de Assiria C e setenta e nueve, e del de Sitionia C y L e ocho, e de cuando Abraham naciera ciento e XXXVII, e del de los tebeos C e XXXVII, e de Isaac su fijo de Abraham e de Sarra XXXVII, e del año del prometimiento de Nuestro Señor Dios a Abraham LXII, regnant en Assiria el rey Aralio, e en Sitionia el rey Egidro, e en Egipto el linage de los tebeos ${ }^{291}$;

I.6.11: «segund cuenta Moisén e Jerónimo, dos mill e cuatrocientos e XXVII años, e de Noé mill e cuarenta e I, e del diluvio quinientos e cuarenta e uno, e del departimiento de las lenguas cuatrocientos e XLI[...].

3.13.2.6. Aparte de los citados, recojo algunas acumulaciones de fuentes: I.25.16: «como dizen los esponedores, como Augustín, Beda, Orígenes, Rabano, Jerónimo e los otros que d'esta razón» (6 fuentes); I.23.22: «E segund departen Jerónimo e Agustín e Josefo e maestre Pedro e Orígenes e Rabano e otros» (7 fuentes); I.14.33 (8: Agustín, Jerónimo, Orígenes, Maese Pedro, Hugucio, Papías, Ebrardo, más la glosa); I.21.prólogo: «Pues de la primera de todas estas razones fablaron Moisén e Josefo e Jerónimo e Teodocio e los LXX Trasladadores, e los esponedores d'ellos, como Augustín, Orígenes, Beda e maestre Pedro e otros muchos» (10 fuentes); I.12.23: «E sobre

ordinaria fue publicada en Estrasburgo, Adolph Rusch, 1480-1481, en cuatro volúmenes. La Patrologia Latina de Migne, volúmes 113 y 114, ofrece una versión del siglo XII (falsamente atribuida durante siglos a Walafrido Strabo, que vivió en 805-849). La Glossa ordinaria puede consultarse en línea: https://gloss-e.irht.cnrs.fr/php/livres-liste.php. Por otro lado, en la $G E$ «la glosa» puede referirse también al proceso de traducción y conversión del texto latino para la versión castellana realizada por el equipo alfonsí, como se ha visto en el caso de las Heroidas ovidianas presentes en la General Estoria: cf. Salvo García, 2009.

${ }^{290}$ Isidoro de Sevilla se ocupó de Túbal en varios lugares. Por ejemplo, en las Etymologiae 9.2.29: Thubal, a quo Iberi, qui et Hispani; licet quidam ex eo et Italos suspicentur.

${ }^{291}$ La muerte de Sara sí consta en Moisés (Biblia), pero el cómputo de los años viene de Eusebio-Jerónimo. 
aquellas razones que vos dixiemos fasta aquí que dixieron en este fecho Moisén e Josefo e maestre Pedro e maestre Godofré fallamos algunas razones más que dixieron ý Agustín, Jerónimo, Beda, Rabano, Strabo, Ambrosio e Paulo Orosio e otros escritos de arávigos» (12 fuentes).

\subsection{Agustín $(52+32$ Augustín=84)}

3.14.1. Su vida se enmarca entre los años 354-430. La $G E$, de entre la nutrida producción del citado, sólo menciona una obra por su título, a saber, dos veces la Ciudad de Dios. Por lo demás abundan las alusiones a los comentarios bíblicos ${ }^{293}$, bien sólo de dicho autor, bien de varios. La $G E$ también lo trae a colación a propósito de la glosa. A lo largo de esta aportación ya hemos encontrado varias veces al autor mencionado: véanse apartados 2.20.2, 2.31.2, 3.5, 3.13.2.4, 3.13.2.6. Por lo demás, con el ánimo de ser útil a futuros investigadores, divido las citas en varios apartados, sin ánimo de ser exhaustivo.

3.14.2. Agustín solo: I.12.15: (dos veces) «Sobr’este logar faze sant Agustín una demanda atal, que esto qué quiso seer que estos encantadores de Faraón pues que non erraron en los primeros dos signos, esto es, en el de la sangre e en el de las ranas, que cómo fallecieron en este tercero de las moscas. E responde e departe el mismo sant Agustín e dize que el que bien lo quisiere entender entendrá por ello que esto fue dicho por mostrarse pora aquí que los filósofos non pudieran conocer»; I.13.8: «Mas contra esto es Agustín, e defiende la guarda d'estos días»; I.14.8; I.14.22 (3, casi seguidas, más otra con «maestre Pedro»); I.14.24; I.14.25; I.14.26; I.14.27; I.14.28; I.14.29; I.14.30; I.14.31 (5 casi seguidos); I.14.34; I.15.2; I.15.24; I.15.55; I.16.10; I.16.24; I.17.25; I.18.7 (3, casi seguidas); I.19.11; I.22.15 (2).

3.14.3. Agustín solo, pero aludiendo, en concreto, a la Ciudad de Dios. I.6.27: «segund departe Agustín en el Libro de la cibdad de Dios»; I.4.9.

${ }^{292}$ Por número de citas ocupa el quinto puesto dentro de la $1^{\text {a }}$ parte de la $G E$. Sobre la presencia de Agustín de Hipona en la GE, cf. Rico, 1972: 3.73; Eisenberg, 1973; de Luis Vizcaino, 2002; Sánchez-Prieto Borja, 2015.

${ }^{293}$ Por ejemplo, la venerable Patrologia latina recoge en los volúmenes 32-44 la enorme producción literaria de Agustín. Para nuestro trabajo son de especial interés sus aportaciones sobre el Génesis (De genesi..., 3 títulos), y las Quaestiones in Heptateuchum, término que abarca los cinco tratados bíblicos abarcados por la GE, en la Primera parte (véase apartado 1.1), más dos recogidos en la Segunda: Josué y Jueces). A diferencia del «Pentateuco» (en griego, transcrito, Pentateûchos, es decir, el conjunto de los cinco estuches donde se guardaban los rollos correspondientes a cada uno de los cinco libros sagrados), el Heptateuchum es un vocablo latino, no registrado en griego, surgido entre los primeros Padres de la Iglesia. 
3.14.4. Agustín solo, pero referido a la glosa: I.3.19; I.5.5; I.6.6: «E segund diz Agustín en la glosa»; I.12.26 (2): «Mas dize Agustín en la glosa sobr'este logar en el XII capítulo dell Éxodo [...] E aún dize más Agustín allí»; I.14.8; I.14.34; I.15.2 (2); I.15.31; I.20.45; I.22.17; I.24.8.

3.14.5. Agustín junto a otro autor. A saber, con Jerónimo: I.2.5: «Sobre que dize Augustín en este logar que fueron las nuves que se abrieron, e aquellas aberturas a que llamava Jerónimo en el traslado de la Biblia en el seteno capítulo del Génesis cataractas dize Augustín que son señaladamientre las puertas del Nilo por ó él sale e mana. Mas diz otrossí que se toma ya este nombre cataracta por cualquier finiestra, e que assí es dicho aquí por las finiestras del cielo» (con 3 alusiones a Agustín; una sin expresar el nombre); I.2.7. Rabano: I.12.15: «assí como dizen otrossí Agustín e Rabano en la glosa»; I.22.3. «Maestre Pedro»: I.3.19; I.14.22: «Mas departe maestre Pedro que por ventura dixo sant Agustín que[...]»; I.20.7: I.22.15. Con «Esiodoro» ${ }^{294}$ : «Sobr’ este logar contra la sangre del vezino nin pararse otrossí contra ella departen Agustín e Esiodoro en la glosa que esto es cuando alguno non puede buscar por sí mal a su vezino e busca vando con quien se pare porque gele pueda buscar».

3.14.6. Agustín y otro autor, más el término «otros»: I.9.33: «De lo ál que dixo adelant que era fermoso de vista e que corrién las fijas sobr'el muro dizen otrossí sant Agustín e maestre Pedro e otros que fue dicho porque Josep era tan fermoso que vencié de fermosura a todos los otros omnes d'aquella sazón», I.1.14: «E aún departen Augustín e maestre Pedro e los otros sabios»; I.14.23; I.14.24.

${ }^{294}$ De ese «Esiodoro» hay muchas dudas. Aparece, además, cuatro veces en $G E$ I.3.8, es decir, en un contexto concreto y muy ligado ( De Jafet, ell hermano menor, e de Noé fallamos que fabla Esiodoro en el Libro de las noblezas e maravillas de Roma»; «Onde cuenta assí Esiodoro que se tomó Noé con Jafet e con los otros sos fijos de Jafet los que en Asia non fincaron e fueron viniendo por Asia poblando como oyestes fasta que llegaron a las riberas del mar Tirreno e del mar de Costantinopla, que es el de medio de la tierra, e ovieron allí navíos, e entraron Noé e Jafet en una nave, e passaron la mar e arribaron a Europa, e començaron a andar por la tierra, veyéndola por escoger ó se assentassen. E cuando llegaron a la tierra a que después dixieron Toscana, a un logar non alueñe ó agora es la cibdat de Roma, semejóles muy buen logar de heredades e montes e aguas acerca de la mar, e poblaron ý una cibdat, e pusiéronle el nombre de Noé»; "Otros dizen que fue una d'aquellas cibdades que Rómulo metió después en el cerco de la cibdat de Roma, e las cercó e las fizo después todas una cibdat, e en esto semeja que acuerda más Esiodoro, e que allí fincaron Noé e Jafet. E en aquella cibdat que fizo e pobló e moró dize Esiodoro que acabó Noé los trabajos d'este mundo e su vida, pues segund las razones dichas fincó Sem en Jerusalem, e ý moró e finó e ý yaze, e Cam en los bactrianos en la cibdad suya de Bactra, que pobló Jeter fijo de Aram, e Jafet con Noé su padre en Roma. E aun dize d'esto más Esiodoro en este logar, que entró Noé con sos fijos en una nave, e que vino a Italia con ellos, e ý pobló e moró e fincó». Para más noticias sobre el citado «Libro de las noblezas e maravillas de Roma», véase lo que adelantamos en apartado 2.2.2. Sobre el mismo, véase nota 186. También Eisenberg, 1973, afirma que dicho título hace referencia a la Graphia aureae urbis Romae, guía medieval sobre la ciudad sagrada. Con respecto al citado «Esiodoro», Niederehe, 1975: 132, sostiene que se desconoce su identidad. 
3.14.7. Agustín y muchos (cuatro o más): I.15.83: «Moisén e Jerónimo e Agustín e otros que acuerdan con ellos» (4); I.17.1: «e dizen sobr'ella Agustín e Orígenes e maestre Pedro e muchos otros sabios esponedores que se trabajaron de esplanarla» (4); I.4.5: «Augustín e Beda e maestre Pedro e Jerónimo e otros» (5); I.14.33: «Agustín e Orígenes e Jerónimo e maestre Pedro e muchos otros sabios» (5); I.12.23 (ya visto en Jerónimo) (6); I.14.22: «Moisén e Josefo e sant Augustín e Orígenes e maestre Pedro e los otros sabios que d'estos mandados fablaron» (6); I.15.57: «E Agustín e Josefo e maestre Pedro e Beda e Orígenes e todos los otros que sobre la razón d'esta tienda fablaron» (6); I.25.16: «e en cabo entended que assí como dizen los esponedores, como Augustín, Beda, Orígenes, Rabano, Jerónimo e los otros que d'esta razón fablan que esto es lo que la estoria de la Biblia muestra en aquel logar» (6); I.2.2: «De la manera de la fechura e de las cámaras d'aquel arca fablan muchos sabios, como Moisén, Josefo, Augustín, Strabo, Teodocio, Símaco e otros» (7); I.23.22: «E segund departen Jerónimo e Agustín e Josefo e maestre Pedro e Orígenes e Rabano e otros» (7); I.15.82: «Moisén e Jerónimo e Josefo e Agustín e Orígenes e maestre Pedro e maestre Godofré, e los otros que d'él fablaron» (8); I.17.25: «Assí como lo avemos por los escritos de Moisén e de Jerónimo e de Josefo e de maestre Pedro e por los dichos de Agustín e de Orígenes e de Beda en las glosas e de todos los otros esponedores, e assí lo otorgan Teodocion en su traslado e los LXX trasladadores en el suyo» (10); I.21.prólogo: «Pues de la primera de todas estas razones fablaron Moisén e Josefo e Jerónimo e Teodocio e los LXX Trasladadores, e los esponedores d'ellos, como Augustín, Orígenes, Beda e maestre Pedro e otros muchos» (10).

\subsection{Orosio $(58)^{295}$}

3.15.1. La vida de Paulo Orosio suele encuadrarse entre los años 383-420. De entre su producción, sobresalen, para nuestro trabajo, sus Historiarum adversum paganos libri VII, a los que, en una ocasión, la GE (1.13.4) llama «Las Estorias de los gentiles». Dicho escrito abarcaba la historia universal desde los comienzos hasta los días del escritor, y tuvo una gran repercusión en los siglos siguientes, no sólo por los muchos datos aportados sobre los pueblos paganos, sino también por la metodología y claridad seguidas al exponerlos. Ya lo hemos visto en apartados 2.1.2 y 2.32.4 (5), 3.6.3, 3.8.2, 3.13.2.6.

3.15.2. Por lo demás, con el ánimo de ser útil a futuros investigadores, divido las citas en varios apartados, sin ánimo de ser exhaustivo.

${ }^{295}$ Por número de citas ocupa el octavo puesto dentro de la $1^{\text {a }}$ parte de la $G E$. Para la presencia e influencia de Orosio en la GE, cf. Lida de Malkiel, 1959-1960; Jiménez, 1972; Eisenberg, 1973; Jiménez Vicente, 1993; Almeida, 2018. 
3.15.3. Orosio solo. Selecciono unos ejemplos. I.2.23: «Africa otrossí comiença en el so algarbe en el mont Atlant e en el mar Atlántico, segund diz Orosio, e como cata a orient tiene de diestro d'allí fasta mediodía, e dell otra parte de como comiença en esse algarve e otrossí en el mar de Cáliz yendo contra orient sube fasta medio de la tierra como Europa»; I.3.28 (2)(sobre Nino):

E cuenta Paulo Orosio que cometió esta guerra e esta conquista andados los dos d'ellos, e que los otros cincuaenta quel fincavan que siempre los visco en guerras e en batallas, e en sangre e en crueleza. E tod esto fue en la partida de Asia e por tod ella, e batallando siempre. E diz Orosio que començó Nino de parte de mediodía, en la frontera e en las riberas del mar Vermejo, la conquista de Asia, e que levantándose d'allí vino guerreando siempre fasta la postremera partida de septentrión. E destruxo las riberas del mar Euxino, e domó todas aquellas yentes, de guisa que los fizo tornar a sí e recebirle por señor, peró eran ellas pocas aún e necias, e non sabidoras d'armas nin de guerra ninguna nin de los bollicios del mundo, como dixiemos;

I.3.30 (10) (dentro de una notable acumulación a propósito de los cuatro reinos principales del mundo): «De los cuatro regnos principales del mundo fabla Paulo Orosio en el comienço del segundo libro cómo por prólogo, e dize assí, que bien asma él, e aun nós otrossí con él, que non á ningún omne a quien asconderse pueda que Dios fizo all omne en este mundo»; I.4.2 «Cuenta Paulo Orosio en el segundo capítulo del primero libro que la tierra <que> yazié entre Tigre e Éufrates, ríos de Asia contra orient que es aquella a que dezimos Mesopotamia»; I.4.21; I.4.24: «e dize Paulo Orosio en el cuarto capítulo del primero libro que tanto era fuerte esta reína Semíramis que semejava a su marido en el esfuerço e en la fortaleza del coraçón, e en la cara e en el vestir al fijo»; I.4.25 (4. Selecciono dos de ellos): «E en cabo de las otras conquistas, assí como dize Paulo Orosio en el cuarto capítulo del primero libro, llegó la reína Semíramis con sus huestes a tierra de India a dar batalla a los indianos, o ques le diessen yl obedeciessen por suyos. E cuenta Orosio que nunca otro lidiador nin guerrero entró a India fueras ende esta reína e el grand Alexandre»; I.4.38:

La reína Semíramis, pues que salió de las armas e se partió de guerras e moró en su casa e començó a andar en paz por sus regnos por ó querié, metió mientes en su fijo ell infante Zaméis, e enamoróse él d'ella e ella d'él. E como no era bien cuerdo, nin entendiendo qué se fazié, ovo con su madre lo que el rey su padre oviera en su vida con ella. E cuenta Orosio qué fizo la reína Semíramis por encobrir el su fecho tan desaguisado e de su fijo, si sonasse de guisa que lo sopiessen los omnes, que serié tenido por cosa mucho estraña además, que mandó en sos casamientos que casasse el padre con la fija, e el fijo con la madre, e el hermano con la hermana e el añado con la madrastra, e dioles soltura que en pleito de casamiento que casasse qui quisiesse con quien se pagasse, que vergüença nin debdo de natura non fuesse ý guardado ninguno por razón del debdo de parentesco;

I.5.7: «E diz este Paulo Orosio que semeja que sale de la ribera ó se comiença el mar Bermejo, e a aquel logar llámanle los griegos Mossille Nemporio, e de allí diz que va contra occident, e passa por muchas tierras, e faze en medio de sí una isla que á nombre Meroe»; I.5.8: «E Paulo Orosio cuenta d'este Nilo todas las cosas 
que dixieron los otros sabios, fueras ende estas dos, la una quel camia él los nombres, la otra en el correr, ca dize él que en algunos logares corre d'otra guisa que non dixieron los otros sabios»; I.5.29 (sobre Sodoma y Gomorra): «assí como diz Paulo Orosio, que creció en ellos sobervia de fazer luxuria en sí mismos desguisada contra ley e contra natura»; I.5.31; I.5.32 (6); I.10.25.

3.15.4. Citado junto a otro. A saber, Platón: I.13.14 (2. Importante por el crédito que la $G E$ le da a Orosio):

E fue Fetón ende rey, assí como lo fallamos en los autores de los gentiles, e contecieron otrossí estonces muchas otras pestilencias grandes por muchas otras tierras, assí como dizen Plato e Orosio e otros que lo retraen por ellos; [...] mas Paulo Orosio, que fue sacerdot e omne bueno e de creer e santo, pone estas pestilencias en el Ix capítulo del su primero libro que fizo de los fechos de los gentiles, e cuéntalas después de las plagas de Egipto mostrando que cuando Nuestro Señor Dios firió a Egipto que firió otrossí en essa sazón misma muchas otras tierras porque creyén todos en dioses de vanidades e en ídolos, e que non creyén a él que les fiziera nin al su poder nil catavan, e aun que non les cumplié esto, mas que se trabajavan de estorvar la su creencia e la su ondra con ell aoramiento de los ídolos, onde tovo por bien que lazrassen por ello, ca lo merecién, e desí que viessen el su poder e croviessen.

Y, además, junto a «Maestre Godofré»: I.3.29: «E diz Orosio en el cuarto capítulo del Primero libro, e maestre Godofré en la setena parte del Panteón, que estudiara allí Cam en los saberes de las siete artes liberales, e assumó las reglas d'ellas, e falló el arte mágica, que es el saber del encantar. E era rey de los bactrianos».

\subsubsection{Con varios autores: I.13.4 (2):}

D'éstos retrae sobr'esta razón Paulo Orosio en el IXº capítulo del su primero libro de las Estorias de los gentiles que dixieron aquel Pompeyo e Cornel cómo vinieran sobre Egipto aquellas plagas que avemos dichas tan grandes e tan desmesuradas de mal que non era yente en el mundo que sofrir las pudiesse. E esto diz Orosio otrossí que fue DCCC e $\mathrm{V}$ años ante que Roma fuesse fecha, e él faze la cuenta del tiempo de las cosas de que esta su estoria fabla, e diz que non cuentan aquel Pompeyo e Justino que aquellas pestilencias sobre los egipcianos oviessen venido por la razón que Moisén dize en la Biblia e los otros que con él acuerdan e como las nós avemos contadas, si non que contecieron allí éstas como por muchas otras tierras antes e estonces e después muchas otras pestilencias, como oiredes adelant que vos contaremos nós algunas d'ellas en este libro, segund que las cuenta Plato e otros;

I.13.5 (2. Elijo un pasaje significativo, pues Alfonso le da la razón al escritor):

Ca dize otrossí Orosio que se non guardaron estos sabios después en sus razones e contaron allí en sus estorias los bienes que los de Egipto recibieron de Moisén e los males que desviaran por él e otrossí por Josep. E diz que comoquier que ellos desmesurados sean contra la verdad en algunas razones que peró pues que en las otras otorgan la verdad de cómo fue que nós estas razones assí las devemos creer 
e tener como Moisén e los otros santos padres e la verdadera ley los cuenta, e esto creemos nós e otorgamos e firmamos, e en esto somos nós de todo nuestro coraçón;

I.13.9 (7 veces. A propósito de las plagas padecidas por los egipcios); etc.

\section{A MODO DE CONCLUSIÓN}

Acabamos aquí esta aportación en que hemos recorrido la recepción en la $G E$ alfonsí, Primera parte, de 32 autores griegos y 15 latinos. En el plano numérico sobresalen las referencias a Josefo (743), Jerónimo (364), Plinio (138), Eusebio (124), Agustín (84), Ovidio (76), los Setenta (59), Orosio (58), Orígenes (52), y, a considerable distancia, Tácito (16), Pompeyo Trogo (12), Aristóteles (11) y los demás. De todo lo dicho creo que se ha visto la enorme labor realizada en el escritorio de Alfonso X, imprescindible para conocer cómo se recibieron los autores de la Antigüedad clásica, así como el uso y la función de los mismos en dicha parte de la General Estoria. No obstante, como hemos comprobado, a los futuros investigadores les queda mucho por hacer. Un capítulo esencial podría ser el estudio de la recepción de autores latinos medievales (algunos de los cuales los hemos citado en este trabajo) dentro de dicha obra. Desde aquí animo a los estudiosos a seguir por esa vía.

RECIBIDO: marzo 2021; ACEPTADO: abril 2021.

\section{REFERENCIAS BIBLIOGRÁFICAS}

FUENTES ${ }^{296}$

1. LITERATURA GRIEGA

1.1. GENERAL

Migne, J. P. (ed.) (1857-1866): Patrologia Graeca, París (161 volúmenes, y un índice general).

$T L G=$ Thesaurus Linguae Graecae (2001'): University of California. Irvine (California) (en línea. Imprescindible para búsquedas de léxico).

\subsection{AUTORES}

JOSEFO

PRIMERAS IMPRESIONES:

Flavius Josephus, De antiquitate judaica. De bello judaico. Contra Apionem, Reynaldus DE Novimagio, Venecia, 1481 (fue la primera vez en que se publicaron juntas las traducciones de esas tres obras).

${ }^{296}$ No he recogido bibliografía específica de cada uno de los autores griegos o romanos, a no ser que estuvieran íntimamente relacionados con la $G E$. Asimismo, y dado el carácter de esta aportación, tampoco menciono los útiles imprescindibles para trabajar en los autores griegos o latinos, tanto en el terreno lingüístico como en el literario. 
Flavius Josephus, Antiquitates Judaicae (1400-1450): Rufinus AQUILEIENSIS interpres (?), manuscrits (Consultado en gallica.bnf.fr). Revisada, asimismo, la impresa, junto con otras obras de Josefo (1499): Albertino VerCELLESE, Venecia (La ofrece la Biblioteca Valenciana. Digital. Ésta es similar a Flavius Josephus, De antiquitate Judaica. De bello Judaico (23 Oct. 1499): Trad. Rufinus AQuileiensis, ed. Hieronymus SQuarZaficus, Albertinus Vercellensis, Venecia. Para [los herederos de] Octavianus Scotus ( $f^{\circ}=$ tij00487000), Bodleian Library, University of Oxford).

Flavii Josephi opera (1544): eds. A. P. ArLeniUs - S. Gelenius, H. Froben - N. EpisCopius, Hieronymus Froben, Basilea (Editio princeps).

MODERnAS:

BLATT, F. (1958): The Latin Josephus. I. Introduction and Text: The Antiquities, Books I-V (Acta Jutlandica, XXX. I.). Universitetsforlaget, Aarhus-Munksgaard, Copenhague (Obra incompleta).

The Latin Josephus Project [Con información relevante sobre ediciones y traducciones del historiador judío. Puede verse en https://sites.google.com/site/latinjosephus/antiquities y en $\underline{A W O L-}$ The Ancient World Online. Desde el 12 de marzo de 2018, este instrumento, muy recomendado, gratis, con respecto a las Antiquitates Iudaicae, en cada página, ofrece tres textos: la transcripción latina del manuscrito Bamberg Ms. Class. 78 (de mediados del IX), el texto griego de Benedikt NiEse (Flavii Iosephi Opera, vol. 1.1887), y la traducción inglesa de William WHISTON, 1737].

El TLG sigue la edición de B. NIESE (1885-1892): Flavii Iosephi opera [Antiquitates Iudaicae, vols. 1-4, Weidmann, Berlín, 1:1887; 2:1885: 3:1892; 4:1890 (repr. 1955); De bello Iudaico, vol. 6, Weidmann, Berlín, 1895 (repr. 1955); Contra Apionem, vol. 5, Weidmann, Berlín, 1889 (repr. 1955)].

\section{LITERATURA LATINA}

\subsection{GENERAL}

Classical Latin Texts (2011'): A Resource Prepared by The Packard Humanities Institute (=PHI), Los Altos. Santa Clarita (California) (última revisión 2015. http://latin.packhum.org (En línea. Imprescindible para búsquedas de léxico. De uso libre).

Migne, J. P. (ed.) (1844-1855): Patrologia Latina, París (217 volúmenes, más 4 volúmenes de Índices, 1862-1865).

UlRICHS, C. L. (1871): Codex urbis Romae Topographicus, Stahel, Würzburg.

\subsection{AUTORES}

Orosio

Pauli Orosii (1573): Aduersus paganos historiarum libri septem ed. F. F. MARCODURANO, Materno Cholino, Colonia (en línea: $\underline{\mathrm{BNE}}$ ).

JUSTINO

Marcus Junianus Justinus (1853): Epitome of the Philippic History of Pompeius Trogus, trad., notas, J. Selby Watson, Henry G. Bohn-Convent Garden, Londres-Nueva York (en línea: bilingüe, latín-inglés). 


\section{JERÓNIMO}

El Cronicón puede consultarse, con el texto latino y traducción inglesa, en https://www.fourthcentury.com/jerome-chronicon. Aquí se tiene acceso a:

1. http://www.tertullian.org/fathers/jerome chronicle 04 latin prefaces.htm (que ofrece el texto latino de R. Helm, Die Chronik des Hieronymus = Hieronymi Chronicon, GCS 47 = Eusebius' Werke 7 (Akademie Verlag, Berlín, 1956). Con el texto electrónico de la Patrologia Latina, corregido con la edición de Fotheringham, J. K. (1923): Eusebii Pamphili Chronici canones latine vertit, adauxit, ad sua tempora produxit S. Eusebius Hieronymus, Humphrey Milford, Londres;

y 2. http://www.tertullian.org/fathers/jerome_chronicle_00_eintro.htm (A saber: DONALSON, M. D. (1996): A translation of Jerome's Chronicon with historical commentary, Mellen University Press, Lewiston.

\subsection{LITERATURA LATINA MEDIEVAL}

JUAN DE GARLAND

Giovanni di Garlandia. Integumenta Ovidii (1933): ed. F. GHISALBERTI, Giuseppe Principato, Mesina-Milán. Godofredo DE Viterbo

Pantheon. Consultado en Gotifredi Viterbiensis Opera $\left(1776^{3}\right)$ : Monumenta Germaniae Historica. Rerum Germanicarum Scriptores Aliquot Insignes... J. Pistorius-B. G. Struve (eds.), J. C. Peezii, Rastibona, vol. 2.

Graphia aureae urbis (1939): R. VALENTINI-G. ZuCCHETTI (eds.), Codice topografico della città di Roma, Tipografa del Senato, Roma, vol. III, pp. 77-110 (en línea).

\subsection{OTROS INSTRUMENTOS CONSULTADOS Y CITADOS}

A Latin Dictionary $\left(1879^{1}\right)$ : revisado y ampliado Ch. T. LEWIS-Ch. SHORT (eds.), Clarendon Press, Oxford (con numerosas ampliaciones y reimpresiones. Ahora en línea).

DEL (Diccionario de la lengua española, Madrid, Real Academia española, 201423 (actualizada, 2020) (en línea).

\section{GENERAL ESTORIA}

Texto seguido: P. SÁNCHEZ-Prieto BorjA - R. DíAz Moreno - E. Trujillo Belso (2006): Edición de textos alfonsies en Real Academia Española: Banco de datos (CORDE) [en línea]. Corpus diacrónico del español. <http://www.rae.es> [7 de marzo 2006]: General Estoria. Primera parte.

\section{ESTUDIOS}

Almaż́n, V. (1963): Lucan in der Primera Cronica General und der General Estoria Alfons des Weisen. Ein Beitrag zur Geschichte der frühen spanischen Prosa (Tesis. Universität Köln), University of Windsor Press.

Almeida Cabrejas, B. (2009): «La sección no conservada de la Quinta Parte de la General Estoria: contenido, fuentes, problemas textuales», en J. Cañas Murillo - F. J. Grande Quejigo J. Roso Díaz (eds.), Medievalismo en Extremadura. Estudios sobre Literatura y Cultura Hispánicas de la Edad Media, Universidad de Extremadura, Cáceres, pp. 461-472. 
Almeida CabrejAS, B. (2013): «Fuente no identificada o amplificatio? Los discursos de Hipermestra, Casandra e Ilia en la General Estoria», Vox Romanica 72: 179-201.

Almeida Cabrejas, B. (2015): «Índice de nombres propios de la Primera parte de la General Estoria», Lemir 19: 281-360 (En este trabajo = Índice).

Almeida CABREJAS, B. (2016): «Entre imaginación y realidad la presencia de los animales en la General Estoria», en X. Cruz Martínez - P. M. Fernández Izaguirre (coords.), De animalibus: la presencia zoológica en la literatura, Facultad de Filosofía y Letras, México, pp. 81-113.

Almeida Cabrejas, B. (2016a): «Maldad y pecado en la General estoria de Alfonso X El Sabio», Revista de El Colegio de San Luis 6 (12): 10-38.

ALMEIDA CABREJAS, B. (2018): «Traducción de Orosio en las estorias alfonsíes: reflexiones sobre el uso de una fuente "fácil"», en S. DEL Rey Quesada - F. DEL BARRio de la Rosa - J. GonZÁlez GÓMEZ (coords.), Lenguas en contacto, ayer y hoy. Traducción y variación desde una perspectiva filológica, Peter Lang, Berlín, 97-116.

Almeida Cabrejas, B. - Trujillo, E. (2008): «Censura y modificación ideológica en la Quinta Parte de la General Estoria de Alfonso X el Sabio», Diálogo de la Lengua 1: 1-14.

ALVAR, C. (2010): Traducciones y traductores: materiales para una historia de la traducción en Castilla durante la Edad Media, Centro de estudios cervantinos, Alcalá de Henares.

AsHTON, J. R. (1944): Ovid's Heroides as translated by Alphonso the Wise. An experiment in Source Study (Tesis), Madison, University of Wisconsin.

Ashton, J. R. (1949): «Putative Heroides Codex Ax as Sources of Alfonsine Literature», Romance Philology 3: 275-289.

AvenozA, G. (2003): «Algunos libros de la biblioteca de Lope García de Salazar», Revista de filología española 83. 1-2, 5-37.

Badía Margarit, A. M. (1958-1959): «La frase de la Primera Crónica General en relación con sus fuentes latinas», Revista de Filología Española 42: 179-210.

Bar-Kochva, B. (2010): Pseudo Hecataeus, On the Jews: Legitimizing the Jewish Diaspora, University of California Press, Berkeley-Los Angeles.

BAutista, F. (2017): «Alfonso X, Bernardo de Brihuega y la General estoria», Atalaya 17 (en línea).

BiZARRI, H. O. (2019): La otra mirada: el «exemplum» histórico, LitVerlag, Zúrich.

BRANCAForte, B. (ed.) (1990): Las Metamorfosis y las Heroidas de Ovidio de la General Estoria de Alfonso el Sabio, Hispanic Seminary of Medieval Studies, University of Wisconsin. Madison.

Caldwell, Th. F. (2015): The Career of Licinius Mucianus (Tesis), University of Melbourne.

CASAS RigalL, J. (1999): La materia de Troya en las letras romances del siglo XIII hispano, Universidade de Santiago de Compostela.

CASAS Rigall, J. (1999a): «Sobre la adaptación de Ilias Latina en el Libro de Alexandre y cuestiones conexas (de Dictis y Dares a Alfonso X)», en S. Fortuño Llorens - T. MARTínez Romero (eds.), Actes del VII Congrés de l'Associació Hispànica de Literatura Medieval (Castelló de la Plana, 22-26 de setembre de 1997), Castelló de la Plana, Publicacions de la Universitat Jaume I, vol. 2, pp. 39-54.

CODOÑER, C. (1990): «Las primera traducciones latinas del latín al romance: la General Estoria», en F. Villar (ed), Studia Indogermanica et Palaeohispanica in Honorem A. Tovar et L. Michelena, Universidad del País Vasco - Universidad de Salamanca, Salamanca, pp. 183-194. 
COUlson, F. - RoY, B. (2000): Incipitarium Ovidianum. A finding Guide for Texts related to the Study of Ovid in the Middle Ages and Renaisance, Publications of the Journal of Medieval Latin, Turnhout.

Cristóbal, V. (2011): «Ovid in Medieval Spain», en J. G. Clark - F. T. Coulson - K. L. McKinley (eds.), Ovid in the Middle Ages, Cambridge University Press, Cambridge, pp. 231-256.

Cristóbal, V. (2015): "Orfeo y otros mitos eróticos en la General Estoria», Cahiers d'études hispaniques médiévales 38.1: 65-89.

Cuesta Torre, M. L. (2007): «Los comentaristas de Ovidio en la General Estoria II», caps. 74-115», Revista de Literatura 19: 137-169.

DE Luis VizCAÍNO, P. (2002): «Las traducciones al castellano de San Agustín», en A. BueNo GarCíA C. ADRADA RAFAEL (eds.), La traducción monacal: valor y función de las traducciones de los religiosos a través de la historia. Actas del coloquio internacional, Diputación Provincial de Soria, Soria, pp. 125-148.

Del Castillo Lebourgeois, N. (2015): «Griegos y troyanos en la General Estoria alfonsí», en M. T. Muñoz García de Iturrospe - L. Carrasco Reija (eds.), Miscellanea latina, Sociedad de Estudios Latinos-Universidad Complutense de Madrid, Madrid, pp. 452-459.

Díez De Revenga, F. J. (1988): «Literatura en las obras históricas de Alfonso X el Sabio», Mester 17.2: 39-50.

EISENBERG, D. (1973): «The General Estoria: Sources and Source Treatment», Zeitschrift für romanische Philologie 89: 206-227.

EKMAN, E. (2013): «Ovid Historicized: Magic and Metamorphosis in Alfonso X’s General estoria», La corónica. A Journal of Medieval Hispanic Languages Literatures and Cultures 42.1: 23-46.

FELDMAN, L. H. (1984): Josephus and Modern Scholarship (1937-1980), W. de Gruyter, Berlín-Nueva York.

Fernández OrdóNÉEZ, I. (1989): La Versión Crítica de la Estoria de España en la Historiografia alfonsí. Estudio y Edición (de Pelayo a Ordoño II) (Tesis), Universidad Autónoma de Madrid.

FERnÁNDEZ OrdóN̄EZ, I. (1992): Las «Estorias» de Alfonso el Sabio, Istmo, Madrid.

FERNÁNDEZ OrdóÑEZ, I. (1993): «Las traducciones alfonsíes de Lucano, Orosio y el Toledano en la General Estoria y en la Estoria de España», en R. Lorenzo Vázquez (coord.). Actas XIX Congreso internacional de Linguiistica y Filoloxía Románicas, Fundación P. Barrié de la Maza, La Coruña, pp. 785-800.

FERnÁNDEZ ORDÓÑEZ, I. (1999): «El taller historiográfico alfonsí. La Estoria de España y la General Estoria en el marco de las obras promovidas por Alfonso el Sabio", en J. MonTOYA - A. RodríGUEZ (coords.), El Scriptorium alfonsi: de los Libros de Astrología a las Cantigas de Santa María, Fundación Universidad Complutense, Madrid, pp. 105-126.

FraKer, Ch. (1996): The Scope of History: Studies in the Historiography of Alfonso El Sabio, The Michigan University Press, Ann Arbor.

FraKer, Ch. (2000): «La General Estoria: Júpiter y la fundación de Troya», Salina, 14: 59-68.

FraKeR, Ch. (2006): «Rhetoric in the Estoria de Espanna of Alfonso el Sabio», Talia dixit 1: 81-104.

Francomano, E. C. (2011): «Castilian Vernacular Bibles in Iberia, ca. 1250-1500», en S. BoYNTON D. J. Reilly (eds.), The Practice of the Bible in the Middle Ages: Production, Reception, and Performance in Western Christianity, Columbia University Press, Nueva York, pp. 315-337.

García GarCía, A. M. (2007): Juba II de Mauritania: traducción y comentario de sus fragmentos, Universidad de La Laguna, La Laguna. 
GARRIDO, R. M. (1993): «Lectura alfonsí de las Heroidas de Ovidio», en A. A. NASCIMENTO - C. ALMEIDA RiberRo (coords.), Actas do IV Congresso da Associaçâo Hispânica de Literatura Medieval (Lisboa, 1-5 Outubro 1991), Cosmos, Lisboa, vol. 4, pp. 283-291.

GINZLER, J. R. (1971): The role of Ovid's Metamorphoses in the General Estoria of Alfonso el Sabio (Tesis), Madison, University of Wisconsin.

GÓmEZ FARIN̄A, L. (2014): «Atlas: la reescritura de un mito a través de los siglos», en C. Esteve MesTre (ed.), El texto infinito: tradición y reescritura en la Edad Media y el Renacimiento, SEMYR, Salamanca, pp. 577-588.

Gómez Jiménez, M. (2018): Proyección del mito de Circe en la literatura hispánica: de la época medieval a la contemporaneidad (Tesis), Universidad Complutense de Madrid.

GONZÁlez DíAZ, S. (2014): Del Génesis a los Andes: Una lectura del diluvio y las cronologías del incario a través de las crónicas (siglos XVI-XVII), (Tesis), Universidad Autónoma de Barcelona.

Herrero Llorente, V. J. (1957): Lucano en España (Tesis), Universidad Complutense de Madrid.

Herrero Llorente, V. J. (1959): «Influencia de Lucano en la obra de Alfonso el Sabio. Una traducción anónima e inédita», Revista de Archivos, Bibliotecas y Museos 67.2: 697-715.

Impey, O. T. (1980): «Ovid, Alfonso X, and Juan Rodríguez del Padrón: two Castilian translations of the Heroides and the beginnings of Spanish sentimental prose», Bulletin of Hispanic studies 57.4: 283-297.

IMPEY, O. T. (2005): «De lealtad y connubio: Hipermestra en la General Estoria», en R. ALEMANY et alii (coords.), Actes del X Congrés Internacional de l'Associació Hispànica de Literatura Medieval, Institut Interuniversitari de Filologia Valenciana, Alacant, vol. 2, pp. 917-928.

JiméneZ, M. C. (1972): Paulus Orosius in Alphonsus X the Wise (Tesis), The University of Michigan.

Jiménez Vicente, M. C. (1993): La razón de estado en Alfonso X el Sabio: Paulo Orosio en la Primera crónica general, Secretariado de Publicaciones, Universidad de Valladolid.

Lauriola, R. - Demetriou, K. N. (eds.) (2015): Brill's Companion to the Reception of Euripides, Brill, Leiden-Boston.

Levenson, D. B. - Martin, Th. R. (2016a): «The Place of the Early Printed Editions of Josephus's Antiquities and War (1470-1534) in the Latin Textual Tradition», en J. BADEN - H. NAJMAN E. TigchelaAR (eds.), Sibyls, Scriptures, and Scrolls: John Collins at Seventy, Brill, LeidenBoston, pp. 765-825.

LeVEnson, D. B. - MARTin, Th. R. (2016b): «The Ancient Latin Translations of Josephus», en H. HowelL CHAPMAN - Z. Rodgers (eds.), A Companion to Josephus, Wiley-Blackwell, Malden (MA.)Oxford, 322-344.

LiDA DE MALKIEL, M. R. (1958-1959, 1959-1960): «La General Estoria: notas literarias y filológicas (I)»; «La General Estoria: notas literarias y filológicas (II)», Romance Philology 12: 111-142; 13: 1-30.

Lida de Malkiel, M. R. (1959): «Josefo en la General Estoria», en F. Pierce (ed.), Hispanic Studies in Honour of I. Gonzalez Llubera, Dolphin Book, Oxford, pp. 163-181.

LÓPEZ FÉREZ, J. A. (1994): «Datos sobre la influencia de la épica griega en la literatura española», en Id. (ed.), La épica griega y su influencia en la literatura española, Ediciones Clásicas, Madrid, pp. 359-409.

LÓpEZ FÉreZ, J. A. (2014): «Memoria histórica y tradición clásica en la General Estoria de Alfonso X el Sabio (Primera Parte)" en I. Grifoll - J. Acebrón - F. SABATÉ (eds.), Cartografies de l’ànima: identitat, memòria i escriptura, Pagès editors, Lleida, pp. 173-200. 
LÓPEZ FÉREZ, J. A. (2015): «Mitos y nombres míticos clásicos en la General Estoria de Alfonso X (Primera y segunda partes)", en J. De LA VIlla POlO et alii (eds.), Ianua classicorum. Temas y formas del mundo clásico, Actas del XIII Congreso español de Estudios clásicos, SEEC, Madrid, vol. 3, pp. 469-526.

LÓpez FÉREZ, J. A. (2020a): «Sobre la recepción de Josefo en la General Estoria de Alfonso X (Primera parte)", Fortunatae 32.2: 325-341.

LOPEZ FÉREZ, J. A. (2020b): «Algunas notas sobre la recepción de autores griegos o latinos en la General Estoria de Alfonso X (Primera parte)», Lectura y Signo 15: 93-140.

LÓPEZ FONSECA, A. - RUIZ ViLA, J. (2019): «De las crónicas o tienpos; de Eusebio-Jerónimo-Madrigal: edición crítica de una adición inédita en la traducción», Cuadernos de Filología Clásica. Estudios Latinos 39.1: 43-67.

Malkiel, Y. (1968-69): «El libro infinido de María Rosa Lida de Malkiel: Josefo y su influencia en la literatura española», Filología (Buenos Aires) 13: 205-226.

Martin, G. (2000): «El modelo historiográfico alfonsí», en Id. (ed.), La historia alfonsí: el modelo y sus destinos (siglos XIII-XV), Casa de Velázquez, Madrid, pp. 9-40.

MENÉNDEZ Pidal, G. (1951): «Cómo trabajaron las escuelas alfonsíes», Nueva Revista de Filología Hispánica 4: 363-380.

Montoya Martínez, J. (1995): «La norma retórica en la obra de Alfonso X», en J. Paredes (ed.), Medioevo y Literatura, Actas del V Congreso de la Asociación Hispánica de Literatura Medieval (Granada, 27 septiembre-1 octubre 1993), Universidad de Granada, Granada, vol. 1, pp. 147-170.

Morreale, M. (1969): «Vernacular scripture in Spain», en G. W. H. Lampe (ed.), The Cambridge History of the Bible, Cambridge University Press, Cambridge, 2.465-492.

Morreale, M. (1982): «La General Estoria de Alfonso X como Biblia», en G. Bellini (ed.), Actas VII AIH (Congreso de la Asociación internacional de Hispanistas. Venecia, 1980), Bulzoni editore, Roma, pp. 767-773.

Moure Casas, A. M. (2008): «Plinio en España: panorama general», RELat (Revista de estudios latinos) 8: 203-237.

NiEDEREHE, H.-J. (1975): Die Sprachauffassung Alfons des Weisen: Studien zur Sprach-und Wissenschaftsgeschichte, Max Niemeyer Verlag, Tubinga.

NieTo IBÁÑ̄eZ, J. M. (2004): «Flavio Josefo en los Antiquitatum Iudaicarum libri IX de Arias Montano», en J. F. Domínguez Domínguez (coord.), Humanae litterae. Estudios de humanismo y tradición clásica en homenaje al profesor Gaspar Morocho Gayo, Universidad de León, Secretariado de Publicaciones y Medios Audiovisuales, León, pp. 367-380.

NOACCO, C. (2006): «Lire Ovide au XII ${ }^{\mathrm{e}}$ siècle: Arnoul d'Orleans, commentateur des Metamorphoses», Troianalexandrina 6: 131-149.

Peláez Benítez, M. D. (1999): «La leyenda troyana en España», en Ead., Pedro de Chinchilla. Libro de la historia troyana, Editorial Complutense S.A., Madrid, pp. 45-58.

PÉrez HerranZ, F. M. (2016): Lindos y tornadizos: El pensamiento filosófico hispano (siglos XV-XVII), Verbum, Madrid.

Perona, J. (1989): «Lenguas, traducción y definición en el Scriptorium de Alfonso X», Cahiers de linguistique hispanique médiévale 14-15: 247-276. 
Perona, J. (1998): «La obra enciclopédica de Alfonso X», en E. Ramón Trives - H. Provencio GARRIGÓs (eds.), Estudios de lingüistica textual: Homenaje al profesor Muñoz Cortés, Universidad de Murcia, Murcia, pp. 345-358.

Puerto Benito, J. J. (2008): The Heroides in Alfonso X's General Estoria: translation, adaptation, use and interpretation of a classical work in a thirteenth-century Iberian History of the world (Tesis), Lexington. Kentucky.

Pym, A. (1996): «The Price of Alfonso's Wisdom: Nationalist Translation Policy in Thirteenth Century Castile», en R. Ellis - R. TiXier (eds.), The Medieval Translator. Traduire au Moyen Âge. Proceedings of the International Conference of Conques (26-29 july 1993), Brepols, Lovaina la Nueva, pp. 448-467.

Rico, F. (1967): "Aristoteles Hispanus: En torno a Gil de Zamora, Petrarca y Juan de Mena», Italia medioevale e umanistica 10: 143-164.

Rico, F. (1972): Alfonso el Sabio y la General estoria: tres lecciones, Ariel, Barcelona.

Rubio ÁlvareZ, F. (1958): «Un fragmento de la traducción hecha por Alfonso el Sabio del poema de Lucano La Farsalia», La ciudad de Dios 171: 83-95.

Rubio Tovar, J. (2014): «La traducción en la General Estoria», La cultura en la Europa del siglo XIII. Emisión, intermediación, audiencia, Actas XL semana de estudios medievales. 2013, Gobierno de Navarra, Departamento de Cultura, Turismo y Relaciones Institucionales, Pamplona, pp. 247-284.

Salvo GarCía, I. (2009): «Las Heroidas en la General Estoria de Alfonso X: texto y glosa en el proceso de traducción y resemantización de Ovidio", Cahiers d Études Hispaniques Médiévales 32: 205-228.

Salvo García, I. (2010a): «Los mitos de la creación de las Metamorfosis de Ovidio (Met. I, v. 5-162) en la General Estoria de Alfonso X», en M. CAstillo LluCH - M. López IZQUierdo (eds.), Modelos latinos en la Castilla Medieval, Vervuert Verlagsgesellschaft-Iberoamericana, MadridFrankfurt, pp. 201-222.

SALVO GARCÍA, I. (2010b): «Autor frente a auctoritas: la recreación de Júpiter por Alfonso X en la General Estoria, Primera parte», Cahiers d'études hispaniques médiévales 33: 63-77.

SALVO GARCíA, I. (2010c): «La materia ovidiana en la General estoria de Alfonso X: problemas metodológicos en el estudio de su recepción», en J. GAMBa CorRAdine - F. BAUTISTA PÉrez (eds.), Estudios sobre la Edad Media, el Renacimiento y la Temprana Modernidad, CiLengua, San Millán de la Cogolla, pp. 359-369.

Salvo García, I. (2012): Ovidio en la General Estoria de Alfonso X (Tesis), Universidad Autónoma de Madrid.

SAlvo GarCía, I. (2012a): «El mito de Icario en la General estoria de Alfonso X», Memorabilia 14: 145-160.

SAlvo GARCíA, I. (2014): "Ovidio y la compilación de la General estoria», Cahiers d Études Hispaniques Médiévales 37: 45-61.

SÁNCHEZ-PRIETO BorJA, P. (1990): «Sobre el modelo latino de la General Estoria (El libro de la Sabiduría en GE3)», Revista de Literatura Medieval 2: 207-252.

SÁNCHEZ-PRIETO BorJA, P. (1994): «La General Estoria como obra de traducción (a propósito de GE3 Sab.)», en M. I. TORO PASCUA (coord.), Actas del III Congreso de la Asociación Hispánica de Literatura Medieval (Salamanca, 3-6 octubre 1989), Biblioteca Española del Siglo XVDepartamento de Literatura Española e Hispanoaméricana, Universidad de Salamanca, vol. 2, pp. 923-932. 
SÁnCHEZ-PRIETo BorJa, P. (2015): «El léxico de la General estoria de Alfonso X el Sabio», Anuario de estudios medievales 45.1: 17-53.

SAquero SuÁreZ-Somonte, P. (2002): «Nuevos datos sobre los orígenes del Renacimiento mitológico en España: Alfonso de Madrigal, El Tostado», en J. L. GIRÓn AlCOnCHEL et alii (eds.), Estudios ofrecidos al profesor José Jesús de Bustos Tovar, Facultad de Filología-Instituto de Estudios almerienses, Madrid, vol. 2, pp. 1135-1146.

SAquero SuÁreZ-SOMONTE, P. - GONZÁlez RoláN, T. (1993): «Aproximación a la fuente latina del "Libro de las generaciones de los dioses de los gentiles" utilizada en la General Estoria de Alfonso X el Sabio», Cuadernos de Filología Clásica. Estudios latinos 4: 93-111.

Solalinde, A. G. (1915): «Intervención de Alfonso X en la redacción de sus obras», Revista de Filología española 2: 283-288.

Solalinde, A. G. (1928): «El juicio de Paris en el Libro de Alexandre y en la General Estoria», Revista de filología española 15: 1-51.

Solalinde, A. G. (1934, 1936): «Fuentes de la General Estoria de Alfonso el Sabio», Revista de Filología española 21: 1-28; 23: 113-142.

TAYlor, B. (2015): «Alfonso X y Vicente de Beauvois», en M. HARO CorTés (coord.), Literatura y ficción: «estorias», aventuras y poesía en la Edad Media, Publicacions de la Universitat de Valencia, Valencia, pp. 447-458.

Thuval, M. (2019): «Flavius Josephus», en A. KuliK - G. BocCACCINI - L. DiTommaso - D. Hamidovic - M. E. STONE (eds.), A Guide to Early Jewish Texts and Traditions in Christian Transmission, Oxford University Press, Oxford, pp. 281-299. 